\title{
VEGETATION, SNOW COVER, AND AIR AND NEAR-SURFACE GROUND TEMPERATURE ACROSS TREELINE IN THE UPLANDS EAST OF THE MACKENZIE DELTA, NORTHWEST TERRITORIES
}

by

Michael J. Palmer, B.Sc.

A thesis submitted to the Faculty of Graduate Studies in partial fulfillment of the requirements of the degree of

Master of Science

Carleton University

Ottawa, Ontario

(C) 2007 Michael J. Palmer 


$\begin{array}{ll}\begin{array}{l}\text { Library and } \\ \text { Archives Canada }\end{array} & \begin{array}{l}\text { Bibliothèque et } \\ \text { Archives Canada }\end{array} \\ \begin{array}{l}\text { Published Heritage } \\ \text { Branch }\end{array} & \begin{array}{l}\text { Direction du } \\ \text { Patrimoine de l'édition }\end{array} \\ \begin{array}{l}\text { 395 Wellington Street } \\ \text { Ottawa ON K1A ON4 }\end{array} & \begin{array}{l}\text { 395, rue Wellington } \\ \text { Ottawa ON K1A ON4 } \\ \text { Canada }\end{array}\end{array}$

Your file Votre référence

ISBN: 978-0-494-33711-0

Our file Notre référence

ISBN: 978-0-494-33711-0

NOTICE:

The author has granted a nonexclusive license allowing Library and Archives Canada to reproduce, publish, archive, preserve, conserve, communicate to the public by telecommunication or on the Internet, loan, distribute and sell theses worldwide, for commercial or noncommercial purposes, in microform, paper, electronic and/or any other formats.

The author retains copyright ownership and moral rights in this thesis. Neither the thesis nor substantial extracts from it may be printed or otherwise reproduced without the author's permission.
AVIS:

L'auteur a accordé une licence non exclusive permettant à la Bibliothèque et Archives Canada de reproduire, publier, archiver, sauvegarder, conserver, transmettre au public par télécommunication ou par l'Internet, prêter, distribuer et vendre des thèses partout dans le monde, à des fins commerciales ou autres, sur support microforme, papier, électronique et/ou autres formats.

L'auteur conserve la propriété du droit d'auteur et des droits moraux qui protège cette thèse. $\mathrm{Ni}$ la thèse ni des extraits substantiels de celle-ci ne doivent être imprimés ou autrement reproduits sans son autorisation.
In compliance with the Canadian

Privacy Act some supporting forms may have been removed from this thesis.

While these forms may be included in the document page count, their removal does not represent any loss of content from the thesis.
Conformément à la loi canadienne sur la protection de la vie privée, quelques formulaires secondaires ont été enlevés de cette thèse.

Bien que ces formulaires aient inclus dans la pagination, il n'y aura aucun contenu manquant.

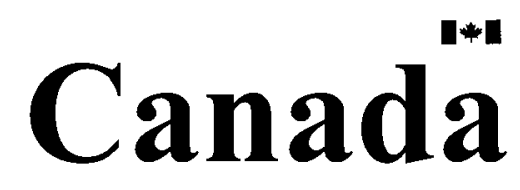




\begin{abstract}
Air and near-surface ground temperatures were recorded for one year, and properties of the vegetation and snow cover were measured at six sites along a 90-km transect across the forest-tundra transition in the uplands east of the Mackenzie Delta, NWT, to investigate the relations between these variables along the ecological gradient. Vegetation height and snow depth decreased northwards along the transect and were positively correlated. Annual mean ground temperatures also decreased northward along the transect, from $-4.0^{\circ} \mathrm{C}$ to $-6.7^{\circ} \mathrm{C}$. A significant drop in annual mean ground temperature $\left(1.1^{\circ} \mathrm{C}\right)$ occurred between the shrubby tussock tundra and the shrub tundra, in association with a significant decrease in mean snow depth between the sites. The variation in annual mean air temperature was only $0.6^{\circ} \mathrm{C}$ between these points, indicating that differences in annual mean ground temperatures were primarily controlled by differences in snow conditions between the sites.
\end{abstract}




\section{Acknowledgements}

Financial support for this thesis was provided through the NSERC Northern Chair to Dr. Chris Burn, the Northern Scientific Training Program, the Polar Continental Shelf Project, and the Water Resources Division of Indian and Northern Affairs Canada in Yellowknife, NWT. Logistical support in the field from the Aurora Research Institute and Les Kutny in Inuvik was greatly appreciated.

I am deeply appreciative of the support that colleagues and friends at the Water Resources Division provided me. In particular, many thanks to Dr. Kathleen Racher, Robert Jenkins, Nathen Richea, and Robin Staples who each helped out in the process of the thesis either through supporting a flexible work schedule, field work, statistical analysis or by getting me out of the house to play hockey.

Work in the field was facilitated with help from Peter Morse, Julian Kanigan, and Thai-Nguyen Nguyen from Carleton University, and Douglas Esagok, Jeffery Amos, and Billy Conley of Inuvik. Kumari "Grandma Permafrost" Karunaratne provided essential advice through the writing of the thesis, from thermal properties of soils to formatting.

Valuable comments on the manuscript were provided by Dr. Michael Pisaric, Dr. Antoni Lewkowicz, and Dr. Elyn Humphreys.

Dr. Steven Kokelj was an integral part of this project and provided much guidance and friendship throughout all stages of the thesis. Thanks "Dr. Steve".

I am indebted to Dr. Chris Burn for introducing me to the "frozen world", and for guiding me through the MSc. process. Thanks Chris.

Finally, none of this would have possible without the love and support of Wendy Lahey. Now it's your turn... 


\section{TABLE OF CONTENTS}

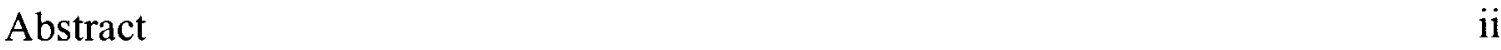

Acknowledgements $\quad$ iii

Table of contents $\quad$ iv

List of tables $\quad$ viii

List of figures $\quad$ xi

1.1 Introduction 1

1.2 Treeline 3

1.3 Research objectives 4

1.4 Structure of the thesis 6

CHAPTER 2: TREELINE, CLIMATE AND PERMAFROST

2.1 Introduction 7

2.2 Treeline 7

2.2.1 The position of treeline 9

2.2.2 Microclimatic influences on the position of treeline $\quad 10$

$\begin{array}{ll}\text { 2.2.3 Climatic change and the position of treeline } & 10\end{array}$

$\begin{array}{ll}2.3 \text { The surface energy balance } & 13\end{array}$

$\begin{array}{ll}\text { 2.3.1 Controls on net radiation }\left(\mathrm{Q}^{*}\right) & 14\end{array}$

2.3.1.1 Change in net radiation $\left(\mathrm{Q}^{*}\right)$ across treeline 15

$\begin{array}{ll}\text { 2.3.2 Controls on latent heat flux }\left(\mathrm{Q}_{\mathrm{L}}\right) & 17\end{array}$

$\begin{array}{ll}\text { 2.3.2.1 Change in latent heat flux }\left(\mathrm{Q}_{\mathrm{L}}\right) \text { across treeline } & 17\end{array}$

$\begin{array}{ll}\text { 2.3.3 Controls on the sensible heat flux }\left(\mathrm{Q}_{\mathrm{H}}\right) & 18\end{array}$

2.3.3.1 Change in the sensible heat flux $\left(\mathrm{Q}_{\mathrm{H}}\right)$ across treeline 18 
2.3.4 Controls on the ground heat flux $\left(\mathrm{Q}_{\mathrm{G}}\right) \quad 20$

2.3.4.1 Change in ground heat flux $\left(\mathrm{Q}_{\mathrm{G}}\right)$ across treeline 20

2.3.5 The effect of snow on $\mathrm{Q}_{\mathrm{G}} \quad 21$

2.4 Relations between vegetation and snow cover 26

2.5 Temperature relations between climate and permafrost 27

2.5.1 Mean annual air temperature $\left(\mathrm{T}_{\mathrm{a}}\right) \quad 28$

2.5.2 Mean annual surface temperature $\left(\mathrm{T}_{\mathrm{s}}\right) \quad 28$

2.5.3 Mean annual temperature at the top of permafrost $\left(T_{p}\right) \quad 30$

2.6 Relations between $\mathrm{T}_{\mathrm{a}}, \mathrm{T}_{\mathrm{s}}$, and $\mathrm{T}_{\mathrm{p}} \quad 31$

2.6.1 The surface offset 31

2.6.2 The n-factor 34

2.6.3 The thermal offset $\quad 35$

3.1 Introduction $\quad 39$

3.2 Inuvik - Swimming Point treeline transect 39

3.2.1 Location and geomorphic setting 39

3.2.2 Climate 44

3.2.3 Present characteristics of treeline near Inuvik 46

$\begin{array}{ll}3.2 .4 \text { Permafrost } & 49\end{array}$

$\begin{array}{ll}3.2 .5 \text { Soils } & 50\end{array}$

3.3 Study period $\quad 52$

3.4 Study design $\quad 55$

3.4.1 Site selection $\quad 55$

$\begin{array}{lll}3.4 .1 .1 \mathrm{~T} 1 & 57\end{array}$

$\begin{array}{lll}3.4 .1 .2 \mathrm{~T} 2 & 57\end{array}$

$\begin{array}{lll}3.4 .1 .3 \mathrm{~T} 3 & 61\end{array}$

3.4.1.4 T4 61

3.4.1.5 T5 62

3.4.1.6 T6 62 
3.4.2 Air and surface temperatures $\quad 62$

3.4.3 Near-surface ground temperatures $\quad 63$

$\begin{array}{ll}3.4 .4 \text { Vegetation and snow courses } & 65\end{array}$

3.4.4.1 Vegetation course $\quad 65$

3.4.4.1.1 Vegetation composition $\quad 65$

3.4.4.1.2 Vegetation height 67

$\begin{array}{ll}\text { 3.4.4.1.3 Structural complexity } & 67\end{array}$

$\begin{array}{ll}\text { 3.4.4.2 Snow course } & 68\end{array}$

3.4.4.2.1 Snow depth and density $\quad 70$

$\begin{array}{ll}3.4 .4 .2 .2 \text { Snow properties } & 70\end{array}$

$\begin{array}{ll}3.4 .5 \text { Soil properties } & 70\end{array}$

$\begin{array}{ll}3.4 .6 \text { Active layer } & 71\end{array}$

\section{CHAPTER 4 PHYSICAL CHARACTERISTICS OF THE STUDY SITES $\quad 72$}

$\begin{array}{lll}4.1 & \text { Introduction } & 72\end{array}$

$\begin{array}{ll}4.2 \text { Vegetation } & 72\end{array}$

4.2.1 Vegetation height across treeline 72

4.2.2 Vegetation structural complexity across treeline $\quad 79$

4.2.3 Vegetation data - snow courses vs logger installations 83

4.2.3.1 Mean vegetation height (MVH) 83

4.2.3.2 Structural complexity (SCX) 85

4.3 Snow 88

4.3.1 Snow depth across treeline $\quad 88$

4.3.2 Snow data - snow courses vs. logger installations 98

$\begin{array}{ll}\text { 4.3.3 Snow density across treeline } & 101\end{array}$

$\begin{array}{ll}4.4 \text { Subsurface conditions } & 105\end{array}$

$\begin{array}{ll}\text { 4.4.1 Organic-layer thickness } & 105\end{array}$

$\begin{array}{ll}\text { 4.4.2 Surface soil moisture } & 108\end{array}$ 
5.1 Introduction

5.2 Air temperatures across treeline

5.2.1 Freezing-season air temperatures

5.2.2 Thaw-season air temperatures

5.3 Surface temperatures across treeline

5.3.1 Freezing-season surface temperatures

5.3.2 Thaw-season surface temperatures

5.4 Air and surface temperatures across treeline

5.4.1 The surface offset

5.4.2 N-factors

5.5 Ground thermal regime

5.5.1 Active-layer temperatures across treeline $\left(T_{50}\right)$

5.5.2 Top of permafrost temperatures

5.7 Climate - permafrost relation 


\section{LIST OF TABLES}

2.1 Surface albedo for tundra and forest under snow conditions and snowless conditions. Data from Rouse (1984a, Table 1a).

2.2 Mean summer surface energy fluxes across treeline near Council, Alaska (Thompson et al., 2004). The woodland site was a mix of tall dwarf-birch and willow shrubs with a low density of white spruce. The forest site was a closed canopy white spruce forest with an understorey of tall willow shrubs.

2.3 Thermal properties of soils and their constituents. From Williams and Smith (1989; Table 4.1) and Burn (2004; Table 3.3.1).

2.4 Surface and thermal offsets from Mayo, YT (Karunaratne and Burn, 2004), and Alaska, USA (Romanovsky and Osterkamp, 1995). Karunaratne (2002, Table 2.3).

3.1 Coordinates for the six study sites along the treeline transect.

3.2 Annual mean 100-cm ground temperatures at sites in Takhini Valley, YT, and near Inuvik and Parsons Lake, NWT. Source: Smith et al. (1998, Table 3).

4.1 Results of the Tamhane T2 post hoc test for the one-way analysis of variance for vegetation height between all six study sites along the treeline transect $(n=15)$. P-values $<0.05$, indicating significant difference between sites, are marked in bold.

4.2 Results from the multiple Mann-Whitney tests for SCX $(n=15)$ between all six study sites along the transect. P-values were adjusted using the Bonferonni correction (Sokal and Rohlf, 1995). P-values $<0.05$, indicating significant difference in median SCX between sites, are indicated in bold.

4.3 Results from the Student's t tests between mean vegetation height along the vegetation transects $(n=15)$ and within a $3-\mathrm{m}$ radius of the ground temperature cable $(n=12)$ at each site. The P-value $<0.05$ is in bold and indicates a significant difference. 
4.4 Results from the statistical tests between SCX along the vegetation transects $(n=15)$ and SCX within a $3-\mathrm{m}$ radius of the ground temperature logger $(n=4)$ at each site. The P-value $<0.05$ is in bold and indicates a significant difference in the means at $\mathrm{T} 1$.

4.5 Mean end of winter snow depths along the treeline transect and the difference in mean snow depth that occurs between adjacent sites.

4.6 Results of the Tamhane T2 post-hoc test for the one-way analysis of variance for snow depth between all six study sites along the treeline transect $(\mathrm{n}=30)$. P-values $<0.05$, indicating significant difference in mean snow depth between sites, are indicated in bold.

4.7 Results from the statistical tests between snow depths along the snow 102 courses $(n=30)$, and snow depths within a $3-m$ radius of the ground temperature logger at each site $(n=5)$. $P$-values $<0.05$ are in bold and indicate significant difference between means (Student's $t$ ) and medians (Mann-Whitney) of the groups.

4.8 Thermal properties of the snow pack at sites T1 to T6.

4.9 Soil properties at sites T1 to T6. Mean active layer soil properties were calculated excluding surface samples $(0-10 \mathrm{~cm})$, as surface samples were predominately organic material. All soil samples were collected between August 13 and 27, 2005.

4.10 Thermal conductivity of the active layer soils at sites T1 to T6. Bulk density and volumetric moisture content are the calculated mean values from the soil profiles excluding surface organics at each site. Porosity and percent saturation for each site are based on these mean values.

5.1 Annual air and surface temperature summary statistics at sites T1 to T6, September 1, 2004 to September 1, 2005.

5.2 Annual, freezing-season, and thawing-season surface offsets at T1 to T6, September 1, 2004 to September 1, 2005.

5.3 Ranking of the study sites by physical characteristics.

5.4 Freezing and thawing $\mathrm{n}$-factors for the study sites.

5.5 Freezeback dates and zero curtain length at $5 \mathrm{~cm}, 50 \mathrm{~cm}$ and $100 \mathrm{~cm}$ below the surface for sites T1 to T6. 
5.6 Annual mean surface temperatures, $50 \mathrm{~cm}$ temperatures, $100 \mathrm{~cm}$ temperatures, and thermal offsets at T1 to T6, September 1, 2004 to September 1, 2005.

5.7 Annual, freezing and thawing-season total offsets at T1 to T6, September 1, 2004 to September 1, 2005. 


\section{LIST OF FIGURES}

1.1 The permafrost zones of Canada (after Heginbottom et al., 1995). 2

1.2 Study area, western Arctic coast, NWT. 5

$2.1 \quad$ Terrestrial ecozones of Canada (Environment Canada, 1995). 8

2.2 Snow - shrub feedback loop. Arrow symbol indicates an increase in the 12 variable. Based on Sturm et al. (2001b).

2.3 Snow-ground interface temperatures recorded on an unspecified day in March 1970, Mackenzie Delta, NWT. Air temperature at the time of measurement was approximately $-25^{\circ} \mathrm{C}$. From Smith (1975, Figure 9).

2.4 Relation between thermal conductivity and density of snow. From

Sturm et al. (1997, Figure 6). Below a density of $0.156 \mathrm{~g} \mathrm{~cm}^{-3}$, a linear regression with y-intercept of $0.023 \mathrm{~W} \mathrm{~m}^{-1} \mathrm{~K}^{-1}\left(\mathrm{k}_{\mathrm{cff}}\right)$ is used. The continuation of the quadratic equation below $0.156 \mathrm{~g} \mathrm{~cm}^{-3}$ is not included in the figure.

2.5 Schematic diagram of mean annual temperature profiles. Based on Henry and Smith (2001, Figure 1).

3.1 Map of the study area. Based on Rampton (1988) and Landhausser and Wein (1993). Study sites are marked by yellow star symbols. The extent of the 1968 forest-tundra fire is marked in green. The southern limit of the low arctic tundra is marked by bold dashed line. The northern limit of the boreal forest is marked by the dotted line.

3.2 Subdivisions of the Tuktoyaktuk Coastlands and Anderson Plain physiographic regions. Based on Rampton (1988, Figure 1).

3.3 Mean monthly temperature and precipitation at Inuvik and Tuktoyaktuk, 1971 - 2000 (Environment Canada, 2004).

3.4 Air photo of the west side of Noell Lake. The limit of the 1968 Inuvik forest-tundra fire is visible as the contrast between green and grey, slightly north of T2. The fire line in this photograph extends from Noell Lake, east of T2, to the eastern shore of Lake AB. Mackenzie Delta and Valley Airphoto Mapping Program. 2005. Airphoto 1:30,000 [L28A31866-25]. Yellowknife, NWT: Indian and Northern Affairs Canada. 
3.5 Mean monthly air temperatures and monthly precipitation normals (1971-2000) at Inuvik (Environment Canada, 2004) compared to mean monthly air temperatures and monthly precipitation totals for the study period (2004-2005) (Environment Canada, 2005).

3.6 Tuktoyaktuk mean monthly air temperatures and monthly precipitation normals (1971-2000) (Environment Canada, 2004) compared to mean monthly air temperatures and monthly precipitation totals for the study period (2004-2005) (Environment Canada, 2005).

3.7 Percent cover of functional types at each site. Totals may be $>100 \%$ because plants are at different strata in the site vegetation.

3.8a Site T1, Inuvik ski club, August 31, 2005.

3.8b Site T2, east of Noell Lake, within the area burned in the 1968 fire, August 18, 2005.

3.8c Site T3, $1 \mathrm{~km}$ north of the 1968 fire line, east of Noell Lake, August 16, 2005.

3.8d Site T4, southeast of Jimmy Lake, August 15, 2005. Air temperature radiation shield is $120 \mathrm{~cm}$ above the ground surface.

3.8e Site T5, west of Parsons Lake, August 2005.

3.8f Site T6, east of Swimming Point, August 24, 2005.

3.9 Study design for snow and vegetation courses, including measurement locations and variables measured.

3.10 Mean snow depth at month end (1971-2000) for Inuvik and Tuktoyaktuk (Environment Canada, 2004).

4.1 Vegetation height (VH) and structural complexity (SCX) along the snow course at sites $\mathrm{T} 1$ to $\mathrm{T} 6$. The triangles represent $\mathrm{VH}$ and SCX, where the vegetation height is less than $300 \mathrm{~cm}$. The circles represent $\mathrm{VH}$ and SCX for spruce trees taller than $300 \mathrm{~cm}$ at $\mathrm{T} 1$.

Note: Vegetation height refers to mean maximum vegetation height within 1-m radius of measurement interval (see section 3.4.4.1.2). 
4.2 Vegetation height (VH) measured at 15 points along $\mathrm{SC} 1$ at the sites $\mathrm{T} 1$ to T6. The vertical lines are drawn between the maximum and minimum VH recorded in August, 2005. The ticks indicate the mean $\mathrm{VH}$. Numbers in brackets are the coefficients of variation for $\mathrm{VH}$ at the sites.

Note: Vegetation height refers to mean maximum vegetation height within $1-\mathrm{m}$ radius of measurement interval (see section 3.4.4.1.2).

4.3 Structural complexity $(\mathrm{SCX})$ at sites $\mathrm{T} 1$ to $\mathrm{T} 6(\mathrm{n}=15)$. The vertical lines are drawn between the maximum and minimum $\mathrm{SCX}$ values recorded in August, 2005. The ticks indicate the mean values for SCX. Numbers in brackets represent the coefficients of variation.

4.4 Vegetation height along the snow course at each site $(n=15)$ and within a $3-m$ radius of the ground temperature logger $(n=12)$. Horizontal lines represent the mean vegetation height at each location. Vertical lines represent the maximum and minimum vegetation height at the sites. Measurements made in August, 2005.

4.5 SCX measurements along the 70-m snow course $(n=15)$ and within a 3 - $m$ radius of the ground temperature logger dowel $(n=4)$. Horizontal lines represent the mean SCX value at each location. Vertical lines represent the maximum and minimum extent of SCX at the locations.

4.6 Snow depths across treeline, end of March 2005. The horizontal lines represent mean snow depth at each site $(n=30)$. The vertical lines represent the range in snow depths at the site. Numbers in parentheses are the coefficients of variation in snow depth.

4.7 Snow depth $(\mathrm{cm})$ and vegetation height $(\mathrm{cm})$ measured along the snow courses at all sites $(\mathrm{n}=90)$.

4.8 Monthly total snow fall (cm) at Inuvik and Tuktoyaktuk, September 2004 - May 2005. Total annual snow fall during the study period at Inuvik and Tuktoyaktuk was $183 \mathrm{~cm}$ and $144 \mathrm{~cm}$, respectively (Environment Canada, 2005).

4.9 Snow cover at T1, November 2005. The snow course along which snow depths were recorded is visible in the foreground of the photograph.

4.10 Patterns of snow drifting around a shrub, March 2005. Note the starshaped formation of the drift. The deep axes of snow surrounding the shrub may represent dominant wind directions. 
4.11 Snow depths along the snow courses $(n=30)$ and within a 3-m radius of the ground temperature loggers $(n=5)$ at each site, March 2005. The horizontal lines represent the mean snow depth at each location. Vertical lines represent the maximum and minimum extent of snow depths at the sites.

4.12 Snow density $\left(\mathrm{g} / \mathrm{cm}^{3}\right)$ at all study sites across the treeline transition, end 103 of March $2005(n=8)$. Vertical lines represent the maximum and minimum extent of snow density at each of the sites. Horizontal lines represent the mean snow density at each site.

4.13 Organic-layer thicknesses $(\mathrm{cm})$ along the snow course at $\mathrm{T} 1$ to $\mathrm{T} 6(\mathrm{n}=$ 15). The vertical lines are drawn between the maximum and minimum organic-layer thickness values recorded in August, 2005. The ticks indicate the mean values for organic-layer thickness.

4.14 Thaw depths $(\mathrm{cm})$ in hummock tops and in interhummock troughs at sites T1 to T6, late August $2005(\mathrm{n}=15)$. The vertical lines are drawn between the maximum and minimum thaw depth values recorded in August, 2005. The ticks indicate the mean values for thaw depth.

5.1 Air temperatures at T1 and T6, September 2004 - September 2005. The air temperature regimes for sites $\mathrm{T} 2, \mathrm{~T} 3, \mathrm{~T} 4$, and $\mathrm{T} 5$ lie within the regimes of $\mathrm{T} 1$ and $\mathrm{T} 6$, therefore, for clarity only the air temperature regimes at $\mathrm{T} 1$ and $\mathrm{T} 6$ are presented. Temperatures were recorded every 4 hours, but the lines represent 5 -day running means.

5.2 The gradient $\left({ }^{\circ} \mathrm{C} / \mathrm{km}\right)$ in air temperature between $\mathrm{T} 1$ and $\mathrm{T} 2$, and between T2 and T6, September 2004 - 2005.

5.3 Mean air temperatures across the treeline transition for: a) freezing season, b) thawing season.

5.45 -cm temperatures at sites T1 to T6, September 2004 - September 2005. Temperatures were recorded every 4-hours, but the lines represent the daily means.

5.5 Mean 5-cm temperatures across the treeline transition for: a) freezing season, b) thawing season.

5.6 Air and 5-cm temperatures at: a) T1; and b) T2, September 2004 to October 2005.

5.7 Five-day running mean of daily surface offset (surface temperature - air temperature) at $\mathrm{T} 1$ and $\mathrm{T} 6$ during the study period. 
$5.8 \quad 50-\mathrm{cm}$ ground temperatures at T1 to T6, September $2004-2005$.

Temperatures were recorded every 4 hours, but the lines represent the daily means.

5.9 Temperatures at the top of permafrost at sites T1 to T6, September 2004 - 2005. Temperatures were recorded every 4 hours, but the lines represent the daily means. 


\section{Chapter 1}

\section{Overview and Objectives}

\subsection{Introduction}

This thesis examines the relations between vegetation, snow cover, and air and ground temperatures across treeline in the continuous permafrost of the western Canadian Arctic (Figure 1.1). Permafrost, which is ground that remains at or below $0^{\circ} \mathrm{C}$ for at least two consecutive years (ACGR, 1988), underlies approximately one-third of Canada's landmass (Zhang et al., 1999).

At continental scale, permafrost temperatures are controlled by climate and ground temperatures decrease as latitude increases (Smith and Riseborough, 2002). However, ground temperatures are variable locally due to microclimatic influences such as vegetation, snow cover, slope angle, soil properties, and aspect (Smith, 1975). The transition between forest and tundra is a significant ecological boundary, and the soil microclimate across the gradient may be strongly influenced by variation in vegetation and snow cover. In turn, this will affect permafrost temperatures.

The consequences of widely anticipated climatic warming in northern Canada (Morrison et al., 2000) may include the northward migration of treeline and an increase in shrubiness of the arctic tundra (Landhausser and Wein, 1993; Myneni et al., 1997; Sturm et al., 2001a). These developments may lead to warming of permafrost, as snow depths may increase where structurally complex vegetation was previously absent (Sturm et al., 2001a). A practical application of such matters is in connection with the recent increase in oil and gas exploration, and the proposed development of the Mackenzie Gas Project 


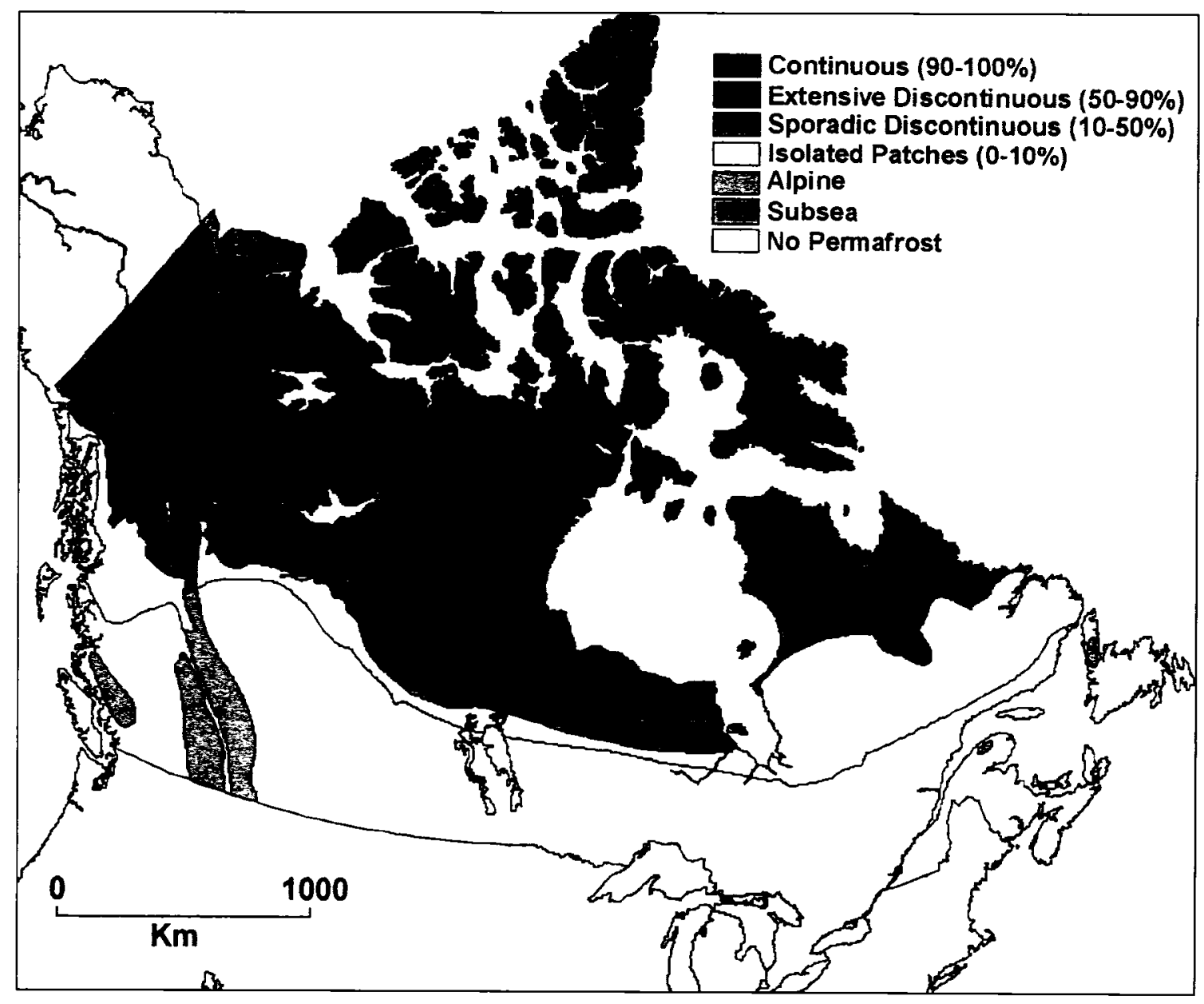

Figure 1.1 The permafrost zones of Canada (after Heginbottom et al., 1995). 
(MGP). Design and regulation of the MGP requires a sound understanding of permafrost conditions across the forest-tundra transition, because buried pipelines of the project's gathering system will traverse treeline.

\section{$1.2 \quad$ Treeline}

Treeline is the latitudinal limit for the growth of trees, and beyond this limit environmental conditions do not permit tree growth (Larsen, 1989). Treeline, however, is not a precise boundary between forest and tundra. The width of the forest-tundra transition in Canada varies from 10 to $15 \mathrm{~km}$ near Inuvik, NWT, to greater than $200 \mathrm{~km}$ in the Keewatin District (Landhausser and Wein, 1993). Treeline in the western Canadian Arctic separates the Taiga Plains ecozone and the Southern Arctic ecozone. The forest-tundra transition is a mix of boreal and tundra vegetation often dominated by large deciduous shrubs (Ritchie, 1984; Timoney et al., 1992).

While relations between vegetation, snow cover, and ground temperature have been studied extensively at the local scale (Mackay and MacKay, 1974; Smith, 1975) and modelled using several one and two dimensional heat transfer models (Goodrich, 1982; Zhang et al., 1996; Ling and Zhang, 2003), these relations have not been investigated in detail at a regional scale across the treeline.

Treeline is a dynamic transition, occurring as a series of ecological stages, heavily influenced by fire history (Ritchie, 1984; Timoney et al., 1992; Landhausser and Wein, 1993; Payette et al., 2001). This thesis addresses how ground temperatures change through the different zones of the forest-tundra transition in the western Canadian Arctic. Differences in ground temperatures across treeline have been identified in annual mean 
ground temperatures (Smith et al., 1998), but seasonal differences have not been investigated.

\subsection{Research objectives}

The purpose of this research is to determine the specific relations which control near-surface ground temperatures along a $90-\mathrm{km}$ transect across treeline, between Inuvik and Swimming Point, NWT, in the western Canadian Arctic (Figure 1.2). Air and ground temperatures and vegetation, snow and soil characteristics at six study sites were examined.

Snow depths decrease northwards across the treeline in association with the decrease in structural complexity of the ecological units (Smith et al., 1998). Snow insulates the ground from frigid atmospheric conditions during winter, and as a result, seasonal ground temperatures tend to be higher beneath thicker snow packs in areas of similar air temperature (Mackay and MacKay, 1974; Smith, 1975). Mean annual nearsurface ground temperatures decrease northwards along the ecological gradient of the forest-tundra transition, and significant differences in seasonal ground temperatures are expected between sites that exhibit large differences in snow depth.

The specific research objectives of this thesis are:

1. To describe air and near-surface ground temperatures at the six study sites across treeline.

2. To describe vegetation and snow cover at the study sites across treeline.

3. To investigate the relations between vegetation, snow cover, and air and ground temperatures over the freezing and thawing seasons at the study sites. 


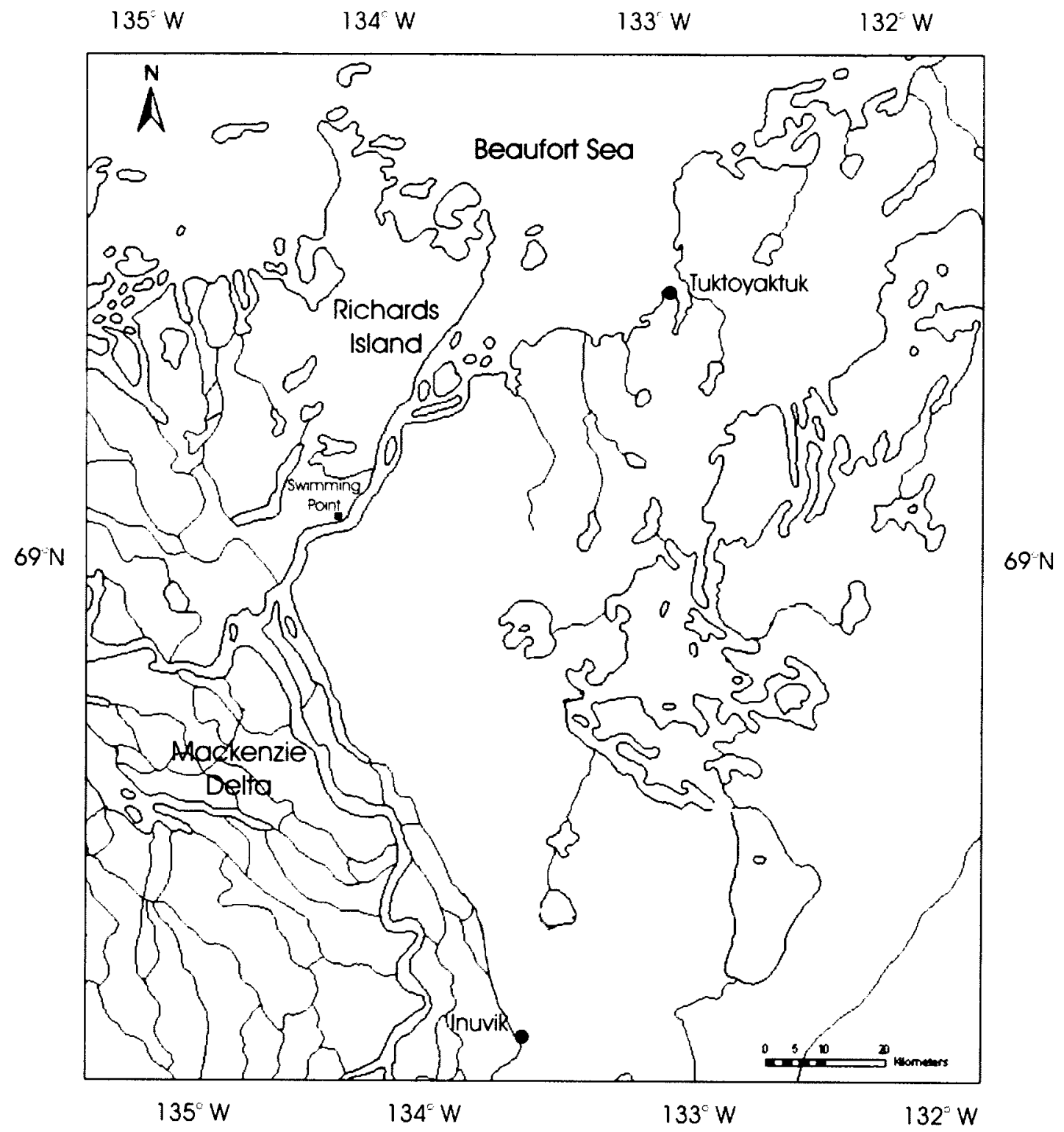

Figure 1.2 Study area, western Arctic coast, NWT. 
4. To determine the surface and thermal offsets at the study sites and to evaluate the relative influences of surface and subsurface conditions on the ground thermal regime.

\subsection{Structure of the thesis}

This thesis is composed of six chapters. The next chapter discusses the position of treeline, the surface energy balance, and the relation between climate and permafrost. Chapter 3 provides a summary of the study area and describes the study design. Chapter 4 describes the physical characteristics of the study sites and examines the relations between vegetation and snow cover. Chapter 5 describes the air and ground thermal regimes at the study sites and examines the relations between vegetation, snow, and air and ground temperatures at the sites. Chapter 6 summarizes the results of this research, presents conclusions and suggests directions for future research. 


\section{Chapter 2}

\section{Treeline, climate and permafrost}

\subsection{Introduction}

An examination of the variation in ground temperatures across treeline requires understanding of: (1) the controls on the position of treeline; (2) the ecology of the foresttundra transition; (3) the relations between air and surface temperature through the surface energy balance; (4) the relations between surface temperature and the temperature at the top of permafrost; and (5) the surface and thermal offsets, and the calculation and application of these variables. This chapter will review the characteristics of treeline and the relations between climate and permafrost in the continuous permafrost zone, and discuss these relations in the context of the forest-tundra transition.

\section{$2.2 \quad$ Treeline}

Treeline is an important ecotone which is both affected by and contributes to the regional climate (Beringer et al., 2005). In this thesis, latitudinal treeline refers to the boundary between the Taiga Plains or Taiga Shield ecozones and the Southern Arctic ecozone (Environment Canada, 1995; Figure 2.1). Treeline is not a sharp boundary, but is a mosaic of forest and tundra, to the north of which is low arctic tundra and to the south is open-crowned subarctic forest (Timoney et al. 1992). Deciduous shrubs are common and may even predominate within the forest-tundra transition, decreasing in size and density towards the northern limit of the zone (Timoney et al., 1992). 


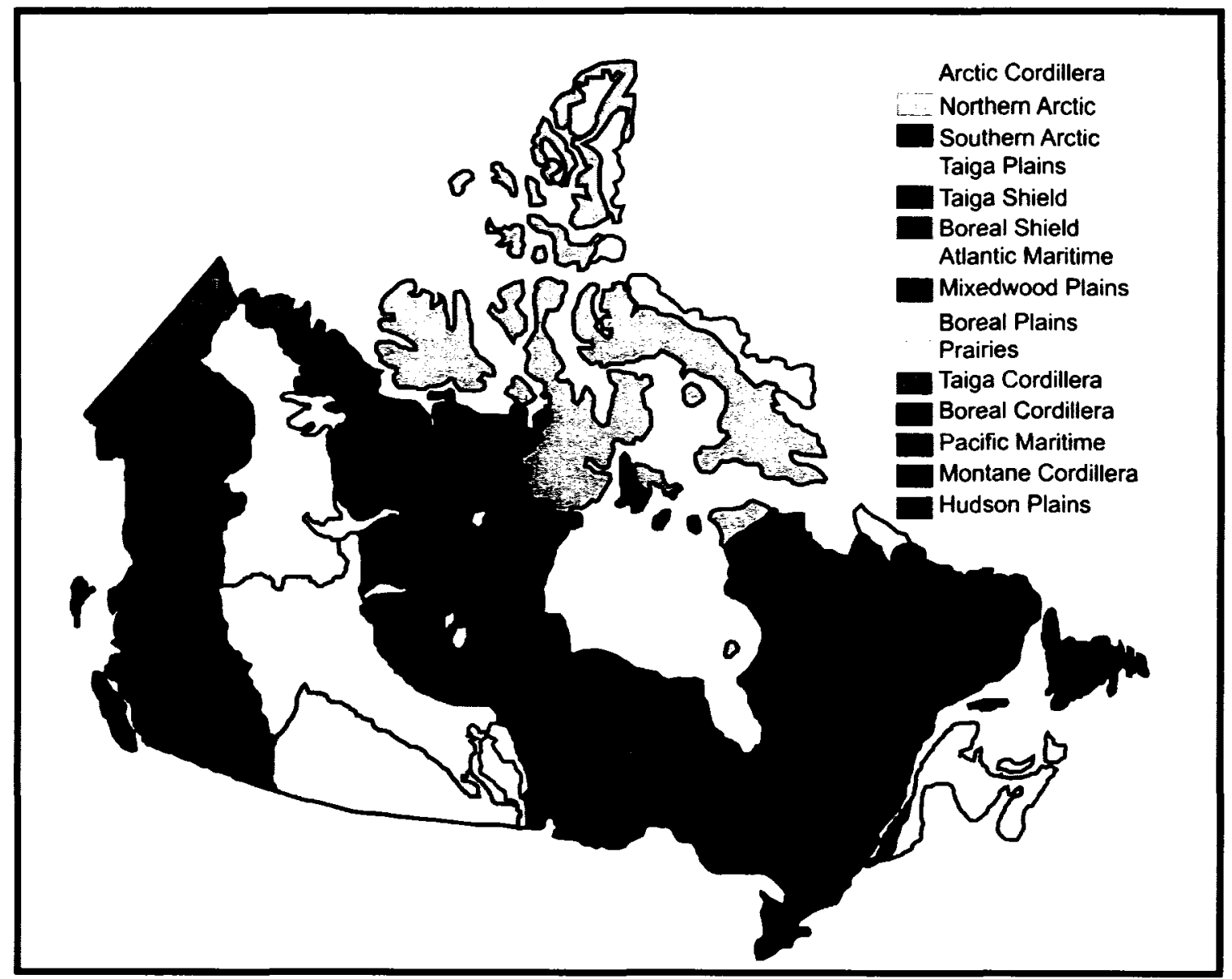

Figure 2.1 Terrestrial ecozones of Canada (Environment Canada, 1995). 
The transition across treeline has significant regional effects on climate, the surface energy balance, the distribution of snow cover, and the thermal regime of permafrost (Rouse, 1984a; Smith et al., 1998; Eugster et al., 2000; Beringer et al., 2005).

\subsubsection{The position of treeline}

At global scale, latitudinal treeline is controlled by climate and is expressed over a circumpolar range (Bryson, 1966; Grace, 1989; Larsen, 1989; Heikkinen et al., 2002). The position of latitudinal treeline in Canada is controlled by the interaction of three air masses: the arctic air mass, the Pacific air mass, and the continental air mass (Bryson, 1966). The location of treeline is determined by the median position of the arctic front in summer, which generally corresponds with the northern limit of the $10^{\circ} \mathrm{C}$ isotherm for the month of July (Bryson, 1966; Barry, 1967; Hare, 1968).

In Canada, the treeline trends from the northwest Yukon Territory, east-southeast to Churchill, Manitoba, on the western shore of Hudson Bay (Payette et al., 2001, Figure 2). East of Hudson Bay, the treeline horizontally traverses northern Quebec and Labrador (Payette et al., 2001, Figure 2). The average width of the latitudinal forest-tundra transition is $145 \mathrm{~km}$, and the width of the transition increases from west to east (Timoney et al., 1992; Payette et al., 2001, Figure 2).

In the northwest, warm Pacific air collides with the cold Arctic air mass and creates the relatively sharp, distinct treeline found in the Mackenzie Delta region (Larsen, 1989). In winter, the Cordillera protects the Arctic air mass from intrusions of warm, moist Pacific air. However, during summer the Arctic air mass recedes and allows the 
intrusion of low pressure cells from the west and the south, resulting in the Western Arctic being the warmest part of Canada for its latitude (Dyke, 2000).

\subsubsection{Microclimatic influences on the position of treeline}

Treeline is a response of vegetation to latitudinally deteriorating climatic conditions (Larsen, 1989). Trees are inhibited from growing north of treeline because of several factors (Hare, 1968; Larsen, 1989): 1) the short growing season; 2) low air temperatures during the growing season, which limit the amount of energy available for photosynthesis and transpiration; 3) desiccating and destructive winds with low humidity, so that the relatively arid climate and the presence of strong winds dry out and damage plant tissue; and 4) nutrient-poor, unstable soils, underlain by permafrost.

White spruce (Picea glauca) and black spruce (P. mariana) dominate the northern boreal forest in North America (Hare and Ritchie, 1972). The far reaches of treeline are also populated by dwarf birch (Betula glandulosa), poplar (Populus sp.), alder (Alnus sp.) and willow (Salix sp.) (Hare and Ritchie, 1972).

\subsubsection{Climatic change and the position of treeline}

The effects of climatic warming are predicted to be greatest at northern latitudes (Morrison et al., 2000; Serreze et al., 2000). In the last 30 years the rate of warming in the Arctic has been about $0.5^{\circ} \mathrm{C}$ per decade, five times greater than the rate of global warming (Serreze et al., 2000). Recent warming has been accompanied by an increase in plant productivity in the region (Myneni et al., 1997), primarily through an increase in shrub abundance (Sturm et al., 2001a). The limits of shrubby tundra tend to move north under warmer atmospheric conditions, replacing tussock tundra near the southern tundra limit (Sturm et al., 2001b). The competitive advantage of arctic shrubs over other plant 
types is due to their high potential for resource uptake in comparison with other arctic functional types (Sturm et al., 2005). Expansion of shrubs into tundra areas has occurred several times in the past, most recently during the late Holocene warming (Payette et al., 1989).

An increase in arctic shrubiness may alter the partitioning of energy in the surface boundary layer in summer (Beringer et al., 2005), and may alter the distribution of snow cover in winter, potentially creating a positive feedback between vegetation, snow depth and ground temperatures (Sturm et al., 2001b; Figure 2.2). The feedback follows from an increase in the structural complexity of the vegetation cover, raising the snow retention capacity of the vegetation, and leading to greater accumulation (Sturm et al., 2001b). An increase in snow depth will inhibit heat loss from the ground during winter, resulting in warmer winter subnivean ground temperatures (Goodrich, 1982). The increase in subnivean ground temperatures may lead to an increase in winter biological activity and decomposition beneath the snow pack, causing, in turn, greater nutrient uptake and deeper root systems (Sturm et al., 2001b). This may facilitate the growth of more structurally complex vegetation, completing the feedback loop (Sturm et al., 2001b).

Wild fire plays an important role in the position of treeline and the distribution of vegetation in the forest-tundra transition and is expected to increase following climate warming (Landhausser and Wein, 1993; Flannigan et al., 2000; McCoy and Burn, 2005). Severe and deep-burning fires are important to the forest-tundra environment because they alter the soil conditions from organic dominated to mineral dominated (Landhausser and Wein, 1993). Immediately after a fire, the active layer in the burned area deepens because of the loss of insulating organic cover, making moisture and nutrients stored in 


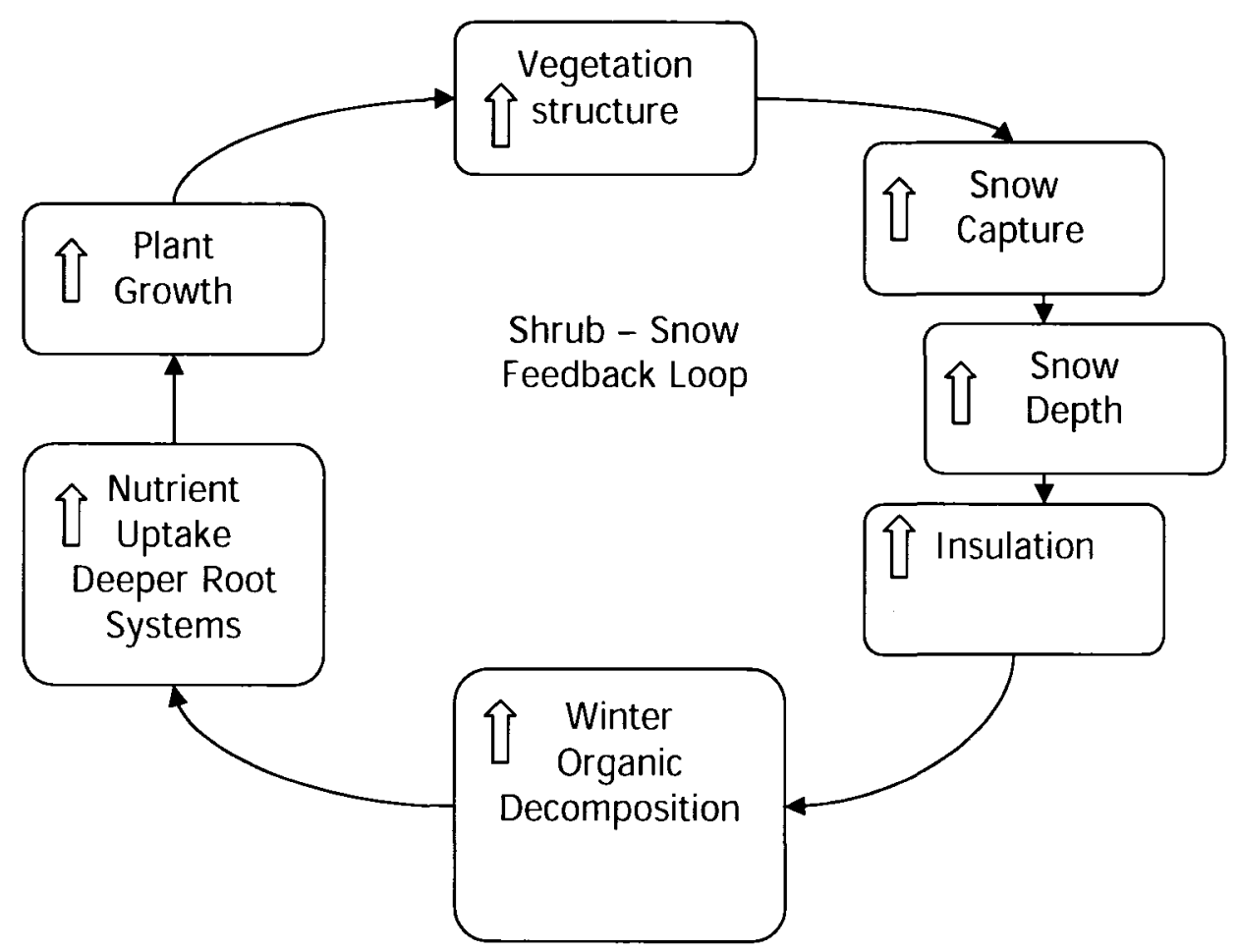

Figure 2.2 Snow - shrub feedback loop. Arrow symbol $\}$ indicates an increase in the variable. Based on Sturm et al. (2001b). 
the uppermost permafrost available for vegetation regrowth (Mackay, 1995; Kokelj and Burn, 2003). Under mineral soil conditions, seedling establishment and growth is enhanced by warmer soils and nutrient availability (Landhausser and Wein, 1993). Shrubs often dominate recently burned areas, especially those close to the treeline limit because of their relative competitive advantage over other functional types at northern latitudes (Landhausser and Wein, 1993).

\subsection{The surface energy balance}

The ground thermal regime is a function of three parameters: ground surface temperature, the geothermal gradient, and thermal properties of earth materials (Burn, 2004). The ground surface temperature is a product of the surface energy balance and, therefore, in an area of uniform climate and soil conditions there may be a wide range in ground temperatures due to variations in vegetation (Smith, 1975; Burn, 2004).

The partitioning of energy at the ground surface is represented by the surface energy balance:

$$
\mathrm{Q}^{*}=\mathrm{Q}_{\mathrm{H}}+\mathrm{Q}_{\mathrm{L}}+\mathrm{Q}_{\mathrm{G}}
$$

Where $\mathrm{Q}^{*}$ is the net radiation $\left(\mathrm{W} \mathrm{m}^{-2}\right)$ available at the ground surface, $\mathrm{Q}_{\mathrm{H}}$ is the sensible heat flux $\left(\mathrm{W} \mathrm{m}^{-2}\right), \mathrm{Q}_{\mathrm{L}}$ is the latent heat flux from evaporation, condensation, and snowmelt $\left(\mathrm{W} \mathrm{m}^{-2}\right)$, and $\mathrm{Q}_{\mathrm{G}}$ is the ground heat flux $\left(\mathrm{W} \mathrm{m}^{-2}\right)(\mathrm{Oke}, 1987)$.

Energy exchanges at the ground surface drive both subsurface temperatures and local climate through the transfer of heat and water between the ground surface and the 
atmosphere. A variety of parameters control the partitioning of the energy fluxes at a location, including: incoming radiation, aerodynamics, the thermal properties of the substrate, and the availability of moisture (Oke, 1987). The fluxes within the surface energy balance respond to differences in these parameters and vary both temporally and spatially, resulting in variations in the ground thermal regime (Oke, 1987).

\subsubsection{Controls on net radiation $\left(Q^{*}\right)$}

$Q^{*}$, the net radiation in the surface boundary layer, is controlled by incoming and outgoing short-wave and long-wave radiation, and can be represented by:

$$
\mathrm{Q}^{*}=(\mathrm{K} \downarrow-\mathrm{K} \uparrow)+(\mathrm{L} \downarrow-\mathrm{L} \uparrow)
$$

Where $\mathrm{K} \downarrow$ represents incoming short-wave radiation, $\mathrm{K} \uparrow$ represents outgoing short-wave radiation, $\mathrm{L} \downarrow$ represents incoming long-wave radiation, and $\mathrm{L} \uparrow$ represents outgoing longwave radiation (Oke, 1987). $Q^{*}$ is predominately controlled by incoming and outgoing short-wave radiation, as the fluxes of long-wave radiation are dependent on the temperature of the atmosphere and the ground surface, which are in themselves influenced by $\mathrm{K} \downarrow$ and $\mathrm{K} \uparrow$.

High latitudes are characterized by large seasonal changes in $\mathrm{K} \downarrow$ because in summer, $\mathrm{K} \downarrow$ is large as the sun maintains a relatively high position in the sky for long periods, whereas in winter there are few hours of sunlight daily and the sun occupies a low position in the sky (Oke, 1987; Hare, 1997). At the local scale, vegetation may act as an agent of shade and block some of the incoming solar radiation, reducing $\mathrm{K} \downarrow$. 
Outgoing short-wave radiation $(\mathrm{K} \uparrow)$ depends on the amount of incoming radiation and the albedo $(\alpha)$, or reflectivity of the ground surface (Oke, 1987).

$$
\mathrm{K} \uparrow=\mathrm{K} \downarrow(\alpha)
$$

Since albedo ranges between 0.05 for water and dark soils to 0.9 for fresh snow, it has a major influence over $\mathrm{Q}^{*}$ and is a powerful determinant of local climate conditions (Oke, 1997). At northern latitudes $K \uparrow$ varies seasonally with $K \downarrow$, and because the albedo of the surface increases once it is covered in snow (Rouse, 1984a).

\subsubsection{Change in net radiation $\left(Q^{*}\right)$ across treeline}

Net radiation is higher in the forest than on the tundra at all times, due to differences in albedo (Rouse, 1984a). This is most pronounced during late winter when the tundra is completely covered in snow and the forest is patterned with dark, radiationabsorbing trees (Table 2.1, Rouse, 1984a). During early spring, when the number of daylight hours increases, the forest canopy may warm up significantly as a result of the absorption of solar radiation by the trees (Rouse, 1984a). In the subarctic boreal forest, structural complexity and total biomass are greater than in tundra environments. This increases the radiation-trapping potential of the canopy. Although the summer difference in albedo between forest and tundra may be small (Table 2.1), the net climate forcing is high due to the number of hours of insolation during summer and, therefore, results in a larger amount of net radiation at forested sites than at tundra sites (Table 2.2; Eugster et al. 2000). 
Table 2.1 Surface albedo for tundra and forest under snow conditions and snowless conditions. Data from Rouse (1984a, Table 1a).

\begin{tabular}{c|ccc}
\hline Surface & Snow Condition & Days of Data & Average Albedo \\
\hline & & & \\
Tundra & Present & 28 & 0.78 \\
Forest & Present & 28 & 0.32 \\
& & & \\
Tundra & No snow & 105 & 0.15 \\
Forest & No snow & 80 & 0.13 \\
\hline
\end{tabular}




\subsubsection{Controls on latent heat flux $\left(Q_{L}\right)$}

The energy consumed as latent heat $\left(\mathrm{Q}_{\mathrm{L}}\right)$ consists of transpiration and evaporation components, and snow and ice melt (Beringer et al., 2005). $\mathrm{Q}_{\mathrm{L}}$ is controlled by the availability of moisture at the ground surface, the temperature gradient between the ground surface and the overlying air, the vapour concentration gradient between the surface and the overlying air, the stomatal resistance of the vegetation cover, and turbulence near the ground surface (Oke, 1987). $\mathrm{Q}_{\mathrm{L}}$ is generally large at wet sites, where surface moisture is readily available, and when the vapour concentration gradient is large. $Q_{L}$ is also high during snow melt when a large amount of energy is devoted to the melting of the snow pack and the thawing of the ground surface. At dry sites, evaporation is limited and $\mathrm{Q}_{\mathrm{L}}$ is low. The latent heat flux is also low in winter, as available energy is limited compared to during summer, although over time, sublimation may remove a significant amount of moisture from the snow pack (Sturm et al., 2001b).

\subsubsection{Change in latent heat flux $\left(Q_{L}\right)$ across treeline}

The overall flux of latent heat is similar at sites across treeline, but the sources which comprise the latent heat flux vary along the gradient (Beringer et al., 2005). Shading of the ground surface decreases across treeline, as the structural complexity of the vegetation cover decreases from forest to tundra. The decrease in shading of the ground surface allows for more net radiation to be partitioned towards evaporation of moisture from the ground surface. At the same time, because there is a decrease in the 
structural complexity of the vegetation across treeline, from forest to tundra, there is also potentially a decrease in transpiration (Beringer et al., 2005).

\subsubsection{Controls on the sensible heat flux $\left(Q_{H}\right)$}

The sensible heat flux is controlled by the temperature gradient between the surface and the overlying air (Oke, 1987). This gradient is influenced by turbulence within the surface boundary layer (Burn, 2004), which is controlled by the size and structural complexity of the vegetation near the ground surface, or the roughness of the surface boundary layer (Oke, 1997). The fraction of net radiation partitioned to the sensible heat flux in the surface boundary layer increases with an increase in roughness (Oke, 1997).

\subsubsection{Change in sensible heat flux $\left(Q_{H}\right)$ across treeline}

The location of the "active" surface, where the majority of energy and mass exchanges occur, varies across treeline. Within tundra environments energy and mass are exchanged close to the ground surface, whereas in forest environments the majority of these exchanges occur close to the top of the forest canopy (Oke, 1987). Thompson et al. (2004) report that the fraction of net radiation partitioned to the sensible heat flux correlated strongly with biomass and roughness, therefore, there is a large increase in $\mathrm{Q}_{\mathrm{H}}$ from tundra to forest (Table 2.2; Thompson et al., 2004). The warming associated with increased sensible heating over more complex canopies could have local effects, including feedbacks to the regional climate by warming the surface boundary layer (Eugster et al., 2000). 
Table 2.2 Mean summer surface energy fluxes across treeline near Council, Alaska (Thompson et al., 2004). The woodland site was a mix of tall dwarf-birch and willow shrubs with a low density of white spruce. The forest site was a closed canopy white spruce forest with an understorey of tall willow shrubs.

\begin{tabular}{|c|c|c|c|c|}
\hline Site & $\begin{array}{c}\text { Net } \\
\text { radiation } \\
\left(\mathbf{W} \mathbf{~ m}^{-2}\right)\end{array}$ & $\begin{array}{c}\text { Ground } \\
\text { heat flux } \\
\left(W \mathrm{~m}^{-2}\right)\end{array}$ & $\begin{array}{c}\text { Latent } \\
\text { heat flux } \\
\left(\mathrm{W} \mathrm{m}^{-2}\right)\end{array}$ & $\begin{array}{c}\text { Sensible hea } \\
\text { flux }\left(\mathrm{W} \mathrm{m}^{-2}\right)\end{array}$ \\
\hline Tundra & 94.1 & 9.4 & 43.3 & 41.4 \\
\hline Low shrub & 92.1 & 6.4 & 43.3 & 42.4 \\
\hline Tall Shrub & 104.1 & 10.4 & 45.8 & 47.9 \\
\hline Woodland & 123.8 & 13.6 & 50.8 & 59.4 \\
\hline Forest & 118.5 & 5.9 & 51.0 & 61.6 \\
\hline
\end{tabular}




\subsubsection{Controls on the ground heat flux $\left(\mathrm{Q}_{\mathrm{G}}\right)$}

The ground heat flux $\left(\mathrm{Q}_{\mathrm{G}}\right)$ is primarily a conductive flux, and refers to the amount of heat that enters and leaves the ground. In relation to the other fluxes within the surface energy balance, the magnitude of $\mathrm{Q}_{\mathrm{G}}$ is low under normal environmental conditions (Table 2.2), due to gentle temperature gradients and low thermal conductivity (Oke, 1997). The direction and magnitude of $\mathrm{Q}_{\mathrm{G}}$ is controlled by the temperature gradient $(\Delta T / \Delta z)$ within the soil and the thermal conductivity $(\lambda)$ of the soil materials (Burn, 2004):

$$
Q_{G}=\lambda\left(\frac{\Delta T}{\Delta z}\right)
$$

During summer the surface is warmer than the ground at depth and therefore $Q_{G}$ is positive and heat moves from the overlying atmosphere into the ground. In permafrost regions, heating of the ground in summer is reduced by the effects of latent heat, as large amounts of energy are required to melt ice in the soil. The heating of the ground is also inhibited by the low thermal conductivity of unfrozen ground. In winter the gradient is reversed and $\mathrm{Q}_{\mathrm{G}}$ is negative. The loss of heat from the ground in winter is facilitated by the relatively high thermal conductivity of frozen ground, but the presence of an insulating snow cover may retard ground heat loss (Goodrich, 1982).

\subsubsection{Change in ground heat flux $\left(Q_{G}\right)$ across treeline}

The fraction of net radiation partitioned to the ground heat flux is controlled by canopy shading (Eugster et al., 2000; Beringer et al., 2005), the insulating properties of 
the ground cover (Burn, 2004; Karunaratne and Burn, 2004), the thermal properties of the ground materials (Table 2.3) (Goodrich, 1982; Williams and Smith, 1989; Burn, 2004), and the temperature gradient within the soil, which is strongly influenced by the presence or absence of permafrost (Karunaratne and Burn, 2004). Shading of the ground surface by the vegetation cover reduces the net radiation available at the ground surface in summer and may contribute to differences in the ground heat flux along the gradient (Beringer et al, 2005). The more significant role of the vegetation cover is through trapping large amounts of snow, which insulate the ground and reduce the loss of heat during winter (Sturm et al., 2001b).

On an annual scale at northern latitudes, variations in winter conditions are more important to the ground heat flux than summer conditions for three reasons: (1) the freezing season is longer than the thawing season; (2) the ground has a higher thermal conductivity in a frozen state than in a thawed state; and (3) the presence of the snow cover imposes a highly effective thermal insulating layer on the landscape. This last point is important as the spatial and temporal variation in snow cover may significantly affect the ground thermal regime at a site. In winter, the movement of heat out of the ground is expected to be greater at tundra sites, where it is not restricted by a thick snow layer.

\subsubsection{The effect of snow on $Q_{G}$}

The snow pack is predominately composed of air, which has a low thermal conductivity (Sturm et al., 1997). Consequently, snow is an extremely effective thermal insulator and acts as a buffer between the ground surface and the air, limiting the loss of heat from the ground (Sturm et al., 1997). The magnitude of $\mathrm{Q}_{\mathrm{G}}$ decreases with an 
Table 2.3 Thermal properties of soils and their constituents. From Williams and Smith (1989; Table 4.1) and Burn (2004; Table 3.3.1).

\begin{tabular}{|c|c|c|c|c|c|}
\hline & $\begin{array}{l}\text { Water } \\
\text { Content } \\
\left(\mathrm{m}^{3} \mathrm{~m}^{-3}\right)\end{array}$ & $\begin{array}{l}\text { Density } \\
\left(\mathrm{kg} \mathrm{m}^{-3}\right)\end{array}$ & $\begin{array}{l}\text { Mass Heat } \\
\text { Capacity } \\
\left(\mathrm{J} \mathrm{kg}^{-1} \mathrm{~K}^{-1}\right)\end{array}$ & $\begin{array}{l}\text { Thermal } \\
\text { Conductivity } \\
\left(\mathrm{W} \mathrm{m}^{-1} \mathrm{~K}^{-1}\right)\end{array}$ & $\begin{array}{l}\text { Thermal } \\
\text { Diffusivity } \\
\left(x 10^{-6} \mathrm{~m}^{2} \mathrm{~s}^{-1}\right)\end{array}$ \\
\hline \multicolumn{6}{|l|}{$\begin{array}{l}\text { Soil } \\
\text { Constituents }\end{array}$} \\
\hline $\begin{array}{l}\text { Quartz } \\
\text { Clay minerals } \\
\text { Organic matter } \\
\text { Water }\left(0^{\circ} \mathrm{C}\right) \\
\text { Ice }\left(0^{\circ} \mathrm{C}\right) \\
\text { Air }\end{array}$ & & $\begin{array}{l}2660 \\
2650 \\
1300 \\
1000 \\
917 \\
1.2\end{array}$ & $\begin{array}{l}800 \\
900 \\
1920 \\
4180 \\
2100 \\
1010\end{array}$ & $\begin{array}{l}8.80 \\
2.92 \\
0.25 \\
0.56 \\
2.24 \\
0.025\end{array}$ & $\begin{array}{l}4.14 \\
1.22 \\
0.10 \\
0.13 \\
1.16 \\
20.63\end{array}$ \\
\hline \multicolumn{6}{|l|}{ Unfrozen soils } \\
\hline $\begin{array}{l}\text { Sandy Soil } \\
\text { (40\% porosity) }\end{array}$ & $\begin{array}{l}0.0 \\
0.4\end{array}$ & $\begin{array}{l}1600 \\
2000\end{array}$ & $\begin{array}{l}800 \\
1480\end{array}$ & $\begin{array}{l}0.30 \\
2.20\end{array}$ & $\begin{array}{l}0.24 \\
0.74\end{array}$ \\
\hline $\begin{array}{l}\text { Clay soil } \\
\text { (40\% porosity) }\end{array}$ & $\begin{array}{l}0.0 \\
0.4\end{array}$ & $\begin{array}{l}1600 \\
2000\end{array}$ & $\begin{array}{l}890 \\
1550\end{array}$ & $\begin{array}{l}0.25 \\
1.58\end{array}$ & $\begin{array}{l}0.18 \\
0.51\end{array}$ \\
\hline $\begin{array}{l}\text { Peat soil } \\
\text { (40\% porosity) }\end{array}$ & $\begin{array}{l}0.0 \\
0.4 \\
0.8\end{array}$ & $\begin{array}{l}300 \\
700 \\
1100\end{array}$ & $\begin{array}{l}1920 \\
3300 \\
3650\end{array}$ & $\begin{array}{l}0.06 \\
0.29 \\
0.50\end{array}$ & $\begin{array}{l}0.10 \\
0.13 \\
0.12\end{array}$ \\
\hline \multicolumn{6}{|l|}{ Peat } \\
\hline $\begin{array}{l}\text { Dry peat } \\
\text { Wet peat } \\
\text { Frozen, wet peat }\end{array}$ & & & & $\begin{array}{l}0.06 \\
0.50 \\
1.10 \\
\end{array}$ & $\begin{array}{l}0.10 \\
0.12 \\
0.68 \\
\end{array}$ \\
\hline
\end{tabular}


increase in the thickness of the snow layer, and, in winter, ground temperatures tend to be warmer beneath a thicker snow pack (Mackay and MacKay, 1974; Goodrich, 1982, Sturm et al., 2001b). Near-surface ground temperatures are most sensitive to changes in air temperature when the snow cover is thin, as the buffering effect of the snow layer is limited under a thin snow cover (Figure 2.3; Mackay and MacKay, 1974).

The insulating properties of the snow pack change over the course of the winter as fresh snow is added and the existing snow pack undergoes metamorphosis, changing the density of the snow (Sturm et al., 1997). As the density of the snow increases, the thermal conductivity increases, and more heat may flow from the ground (Figure 2.4; Sturm et al., 1997).

Several other properties of the snow pack influence the flow of heat from the ground in winter, including: the depth-hoar fraction (Zhang et al., 1996; Sturm and Benson, 1997), and the timing and duration of the snow cover (Rouse, 1984a; Ling and Zhang, 2003). Depth-hoar is a layer of elongated, loosely bonded crystals at the base of a snow pack, which forms by vapour movement in the presence of large temperature gradients (Sturm and Benson, 1997). The low density of the depth-hoar layer significantly reduces the thermal conductivity of the snow pack (Zhang et al., 1996). Deep snow associated with taller, denser shrubs is a better insulator per unit thickness than thinner snow cover because it generally contains a higher depth-hoar percentage (Sturm et al., 2001b).

Changes in the timing and duration of the snow cover affect surface albedo and the insulating properties of the buffer layer, thus altering the surface energy balance, the ground thermal regime, and, ultimately, permafrost temperatures (Ling and Zhang, 2003). 


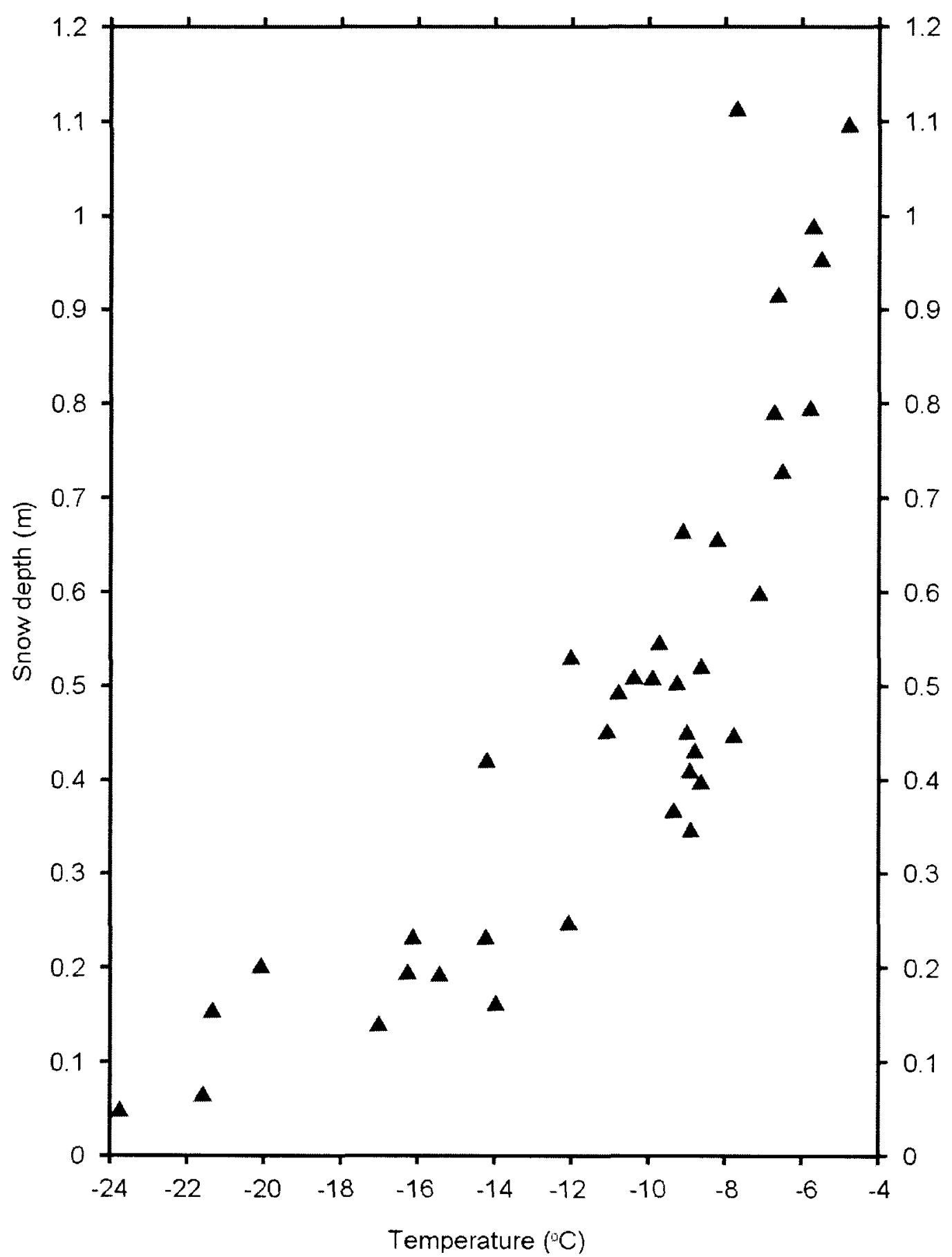

Figure 2.3 Snow-ground interface temperatures recorded on an unspecified day in March 1970, Mackenzie Delta, NWT. Air temperature at the time of measurement was approximately $-25^{\circ} \mathrm{C}$. From Smith (1975, Figure 9). 


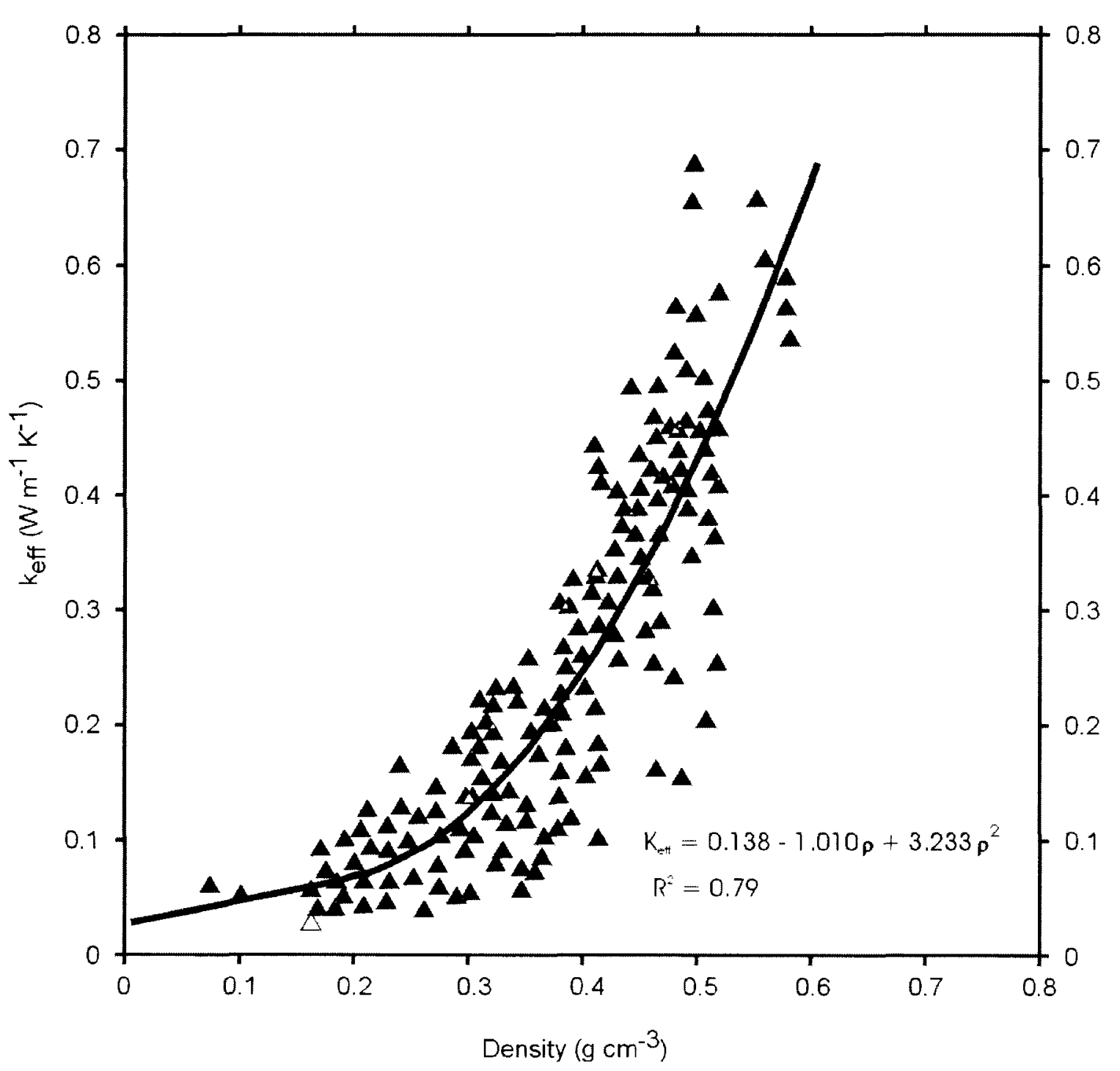

Figure 2.4 Relation between thermal conductivity and density of snow. From Sturm et al. (1997, Figure 6). Below a density of $0.156 \mathrm{~g} \mathrm{~cm}^{-3}$, a linear regression with y-intercept of $0.023 \mathrm{~W} \mathrm{~m}^{-1} \mathrm{~K}^{-1}\left(\mathrm{k}_{\mathrm{eff}}\right)$ is used. The continuation of the quadratic equation below 0.156 $\mathrm{g} \mathrm{cm}^{-3}$ is not included in the figure. 
An early snowfall may delay freezeback of the active-layer and sustain warm ground temperatures for several months (Ling and Zhang, 2003). An early disappearance of the snow pack will expose the ground surface to warmer temperatures. The ground warming due to an early disappearance of the snow pack is further increased, as snow melt at high latitudes occurs close to the summer solstice (Ling and Zhang, 2003).

\subsection{Relations between vegetation and snow cover}

The distribution of snow cover across treeline is primarily influenced by the change in structural complexity of the vegetation (Smith et al., 1998). Wind and topography also contribute to the distribution of snow, but in the context of the regional distribution across treeline they are secondary and complementary influences.

The relations between snow depth and vegetation have been studied extensively (e.g. Nicholson and Granberg, 1973; Smith, 1975; Pomeroy and Gray, 1995; Sturm et al., 2001b). Shrubs and trees catch snow by reducing near-ground wind speeds and by physically trapping snow particles in their branches (Sturm et al., 2001b). Small differences in shrub density and canopy height may lead to large differences in snow depth (Sturm et al., 2001b, Figures 1 and 2). Where tundra vegetation is too small and its branch matrix is insufficient to significantly reduce windspeed, snow tends to be swept away and accumulates in topographic depressions (Mackay and MacKay, 1974). The shrubby vegetation of the forest-tundra transition reduces windspeeds and traps snow within its branch matrices and plant structure, and therefore snow drifts accumulate in these areas (Sturm et al., 2001b, Figure 2). Wind speed close to the ground surface is controlled by friction with the surface layer. Friction of the surface layer is controlled by 
the surface roughness $\left(Z_{0}\right)$, which is influenced by the size and structural complexity of the surface vegetation $(O k e, 1987)$. Surface roughness $\left(Z_{o}\right)$ is low for smooth or moderately rough surfaces, such as ice or tundra, and as a result the surface may be exposed to high winds, allowing for redistribution of the snow cover. Surface roughness $\left(Z_{o}\right)$ is high for rough surfaces such as forests or shrubby tundra. Near-surface wind speeds are significantly reduced in these areas, so the snow pack tends not to be redistributed (Oke, 1997).

The snow cover of the windblown tundra is very different from the more protected forested areas south of treeline (Mackay and MacKay, 1974). Snow cover is generally thinner north of treeline, on the tundra, due to two factors. First, snow cover on the tundra is readily redistributed by wind. Second, the lack of wind-reducing vegetation on the tundra results in snow being suspended for long periods of time, which reduces the amount of snow in an area via sublimation. Sturm et al. (2001b) report that up to $25 \%$ of tundra snow cover may be returned to the atmosphere via sublimation.

The density of the snow pack varies across treeline, as the density is generally higher on the tundra due to windpacking (Mackay and MacKay, 1974). The snow pack may be sufficiently cohesive for ice-wedge cracks to propagate upwards through a cover of $75 \mathrm{~cm}$ of snow to the surface (Mackay and MacKay, 1974).

\subsection{Temperature relations between climate and permafrost}

The partitioning of the fluxes within the surface energy balance controls the temperature regime at the ground surface. However, measurement of the individual fluxes of the surface energy balance throughout the year is logistically difficult at 
multiple sites. It is therefore more practical to describe the relations between climate and permafrost using surface and thermal offsets, which are described by the interaction of three mean annual temperature regimes (Figure 2.5): 1) the mean annual air temperature $\left.\left(T_{a}\right) ; 2\right)$ the mean annual ground surface temperature $\left(T_{s}\right)$; and 3$)$ the mean annual temperature at the top of permafrost $\left(T_{p}\right)$.

\subsubsection{Mean annual air temperature $\left(T_{a}\right)$}

Air temperature is controlled by climate, which is influenced by both synoptic and physical factors (Hare, 1997). The physical component of climate is controlled by surface energy exchanges, which are highly variable at a local scale. The synoptic component of climate is influenced by imported or advected forces, and is influenced by, and influences, climate at a regional scale (Hare, 1997).

\subsubsection{Mean annual surface temperature $\left(T_{s}\right)$}

The mean annual surface temperature $\left(T_{s}\right)$ is controlled by the surface energy balance, which represents the fluxes of energy within the surface boundary layer (Burn, 2004). At any time the temperature at the ground surface is a product of ambient air conditions (wind, cloud cover, relative humidity), surface conditions (vegetation cover, snow cover, surface water) and subsurface conditions (moisture content, bulk density, lithology). Any combination of the surface energy fluxes has a unique value of $T_{s}$, which, in turn, drives subsurface temperatures. 


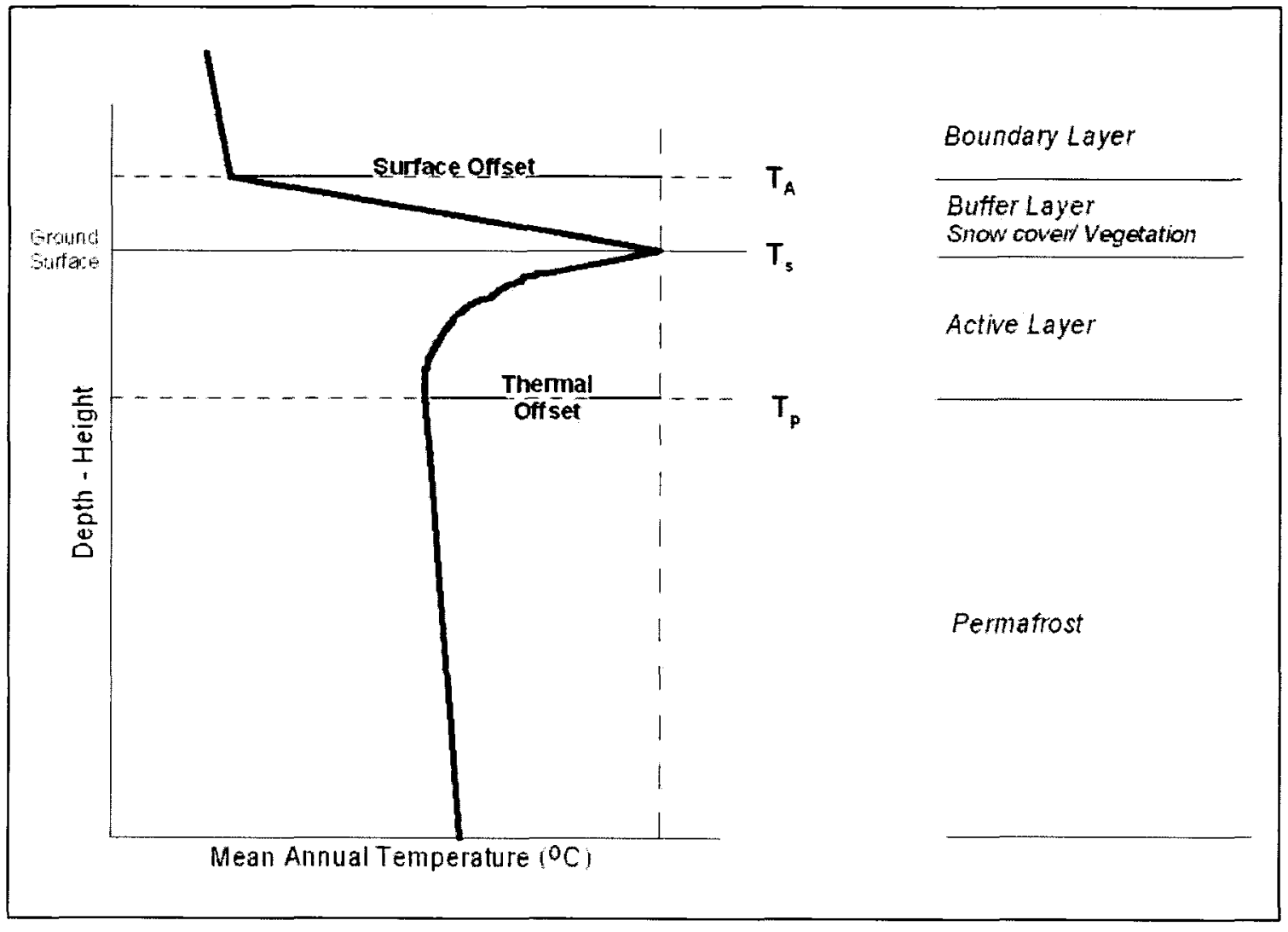

Figure 2.5 Schematic diagram of mean annual temperature profiles. Based on Henry and Smith (2001, Figure 1). 


\subsubsection{Mean annual temperature at the top of permafrost $\left(T_{p}\right)$}

Subsurface temperatures are predominately controlled by the temperature at the ground surface and the thermal properties of the subsurface materials. The thermal conductivity, the thermal diffusivity and the heat capacity of the active-layer materials all influence the temperature at the top of permafrost.

The thermal conductivity $\left(\lambda ; \mathrm{W} \mathrm{m}^{-1}{ }^{\circ} \mathrm{C}^{-1}\right)$ is the ability of a material to conduct heat (Williams and Smith, 1989). The thermal conductivity of the ground depends on the moisture content, the bulk density, and the lithology of the soil, and whether the soil is frozen or unfrozen.

The change in soil temperature depends on the specific heat capacity $\left(\mathrm{C} ; \mathrm{J} \mathrm{kg}^{-1}\right.$ ${ }^{\circ} \mathrm{C}^{-1}$ ) of the soil. The specific heat capacity is the heat required to change $1 \mathrm{~kg}$ of a material by $1^{\circ} \mathrm{C}$ and is expressed by the temperature change produced as a result of gaining or losing heat (Oke, 1987). The heat capacity of the active layer changes seasonally as the water content of the soil varies in summer, and the proportion of water versus ice varies through the winter (Table 2.3). The apparent heat capacity includes the effects of latent heat in the soil at temperatures near $0^{\circ} \mathrm{C}$ (Williams and Smith, 1989). To change the temperature of a moist soil from $1^{\circ} \mathrm{C}$ to $0{ }^{\circ} \mathrm{C}$, an amount of energy, equal to the heat capacity, is removed from the soil. For the same moist soil to cool to a temperature below $0{ }^{\circ} \mathrm{C}$, and undergo phase change, the same amount of energy is required to be removed, in addition to the amount of latent heat released, therefore the heat capacity appears to be larger. 
Soil thermal diffusivity $\left(\kappa ; \mathrm{m}^{2} \mathrm{~s}^{-1}\right)$ refers to the ability of a soil to propagate a temperature wave (Williams and Smith, 1989). These three soil thermal parameters are related by:

$$
\kappa=\frac{\lambda}{C}
$$

In soils where a phase change occurs, as in the active layer, the thermal diffusivity is dominated by the latent heat of fusion $\left(\mathrm{L}_{\mathrm{f}}\right)$. The large increase in the apparent heat capacity of a soil undergoing phase change causes a large decrease in the thermal diffusivity of the soil, as shown by equation 2.5 (Williams and Smith, 1989). This is referred to as the apparent thermal diffusivity.

The presence of water and ice close to their transition temperature has a dominant effect on the thermal properties of frozen soils (Williams and Smith, 1989). When water changes to ice, its conductivity increases four-fold, it specific heat capacity decreases by half and it releases a large amount of latent heat (Gold and Lachenbruch, 1973; Table 2.3). Because of these effects, soil moisture content plays an extremely important role in determining the thermal properties of soils and, ultimately, the temperature at the top of permafrost (Williams and Smith, 1989).

\subsection{Relations between $T_{a}, T_{s}$, and $T_{p}$}

\subsubsection{The surface offset}

The surface offset is defined as the difference between the annual mean air temperature $\left(T_{a}\right)$ and the annual mean surface temperature $\left(T_{s}\right)($ Figure 2.5; Riseborough and Smith, 1998). The surface offset is primarily controlled by the snow cover and the 
thermal diffusivity of the active-layer, but is also influenced by the vegetation cover and the amount of moisture in the active layer (Karunaratne and Burn, 2004).

The vegetation cover can affect the surface offset in two ways. The primary influence of vegetation on the surface offset is indirect, by acting as a snow catchment and influencing the distribution of snow cover at a site. Second, vegetation influences the surface offset by shielding and intercepting incoming solar radiation (Henry and Smith, 2001). During winter the snow cover acts as a thermal buffer layer between the ground surface and the atmosphere. Snow inhibits the loss of heat from the ground, so surface temperatures are decoupled from air temperatures. The surface offset increases with an increase in snow depth (Romanovsky and Osterkamp, 1995).

The surface offset is large during the thawing season until the thaw front has passed below the depth of diurnal temperature fluctuation, and at this point the daily surface offset approaches zero (Karunaratne and Burn, 2004). Apparent thermal diffusivity controls the rate of descent of the frost table, therefore the surface offset is dependent on this property (Karunaratne and Burn, 2004). Table 2.4 shows the surface offset from several sites near Mayo, YT, and the Alaskan north coast. The surface offset tends to be small at dry sites with little snow cover, because the thermal diffusivity of the ground is high and the ground cools rapidly in winter. The surface offset is large at sites with no permafrost because warm surface temperatures are maintained in winter due to the release of latent heat supplied as the subjacent ground freezes (Karunaratne and Burn, 2004). 
Table 2.4 Surface and thermal offsets from Mayo, YT (Karunaratne and Burn, 2004), and Alaska, USA (Romanovsky and Osterkamp, 1995).

\begin{tabular}{lcccl}
\hline Site & $\begin{array}{c}\text { Surface } \\
\text { offset }\end{array}$ & $\begin{array}{c}\text { Thermal } \\
\text { offset }\end{array}$ & $\begin{array}{c}\text { Snow depth } \\
\text { (cm) }\end{array}$ & Site Description \\
\hline $\begin{array}{l}\text { Franklin } \\
\text { Bluff, AK }\end{array}$ & 6.76 & -1.03 & - & $\begin{array}{l}\text { Alaskan coastal plain, wet } \\
\text { tundra, low centred } \\
\text { polygonal relief } \\
\text { Moist tundra, covered in } \\
\text { grasses }\end{array}$ \\
$\begin{array}{l}\text { Deadhorse, } \\
\text { AK }\end{array}$ & 6.70 & -0.68 & - & $\begin{array}{l}\text { Moist tundra, covered in } \\
\text { grasses and dwarf shrubs }\end{array}$ \\
$\begin{array}{l}\text { West } \\
\text { Dock, AK }\end{array}$ & 3.90 & -0.74 & - & $\begin{array}{l}\text { Undisturbed permafrost in } \\
\text { glaciolacustrine sediments }\end{array}$ \\
$\begin{array}{l}\text { UPL, } \\
\text { Mayo, YT }\end{array}$ & 4.2 & -3.8 & 42 & $\begin{array}{l}\text { Undisturbed permafrost in } \\
\text { alluvial sediments }\end{array}$ \\
$\begin{array}{l}\text { UPA, } \\
\text { Mayo, YT }\end{array}$ & 4.2 & -2.8 & 40 & $\begin{array}{l}\text { Dry site with permafrost } \\
\text { and organic surface layer }\end{array}$ \\
$\begin{array}{l}\text { DPO, } \\
\text { Mayo, YT }\end{array}$ & 2.9 & -1.4 & 31 & $\begin{array}{l}\text { Thawing permafrost in } \\
\text { thaw slump }\end{array}$ \\
$\begin{array}{l}\text { TPS, } \\
\text { Mayo, YT }\end{array}$ & 6.5 & -1.6 & 43 & \\
$\begin{array}{l}\text { *In both studies surface temperature measurements were made } 2 \text { cm below the ground } \\
\text { surface. Organic material was considered part of the ground. }\end{array}$
\end{tabular}


The surface offset has been used in association with regional air temperature maps to determine the distribution of permafrost (Henry and Smith, 2001). Riseborough and Smith (2002) propose that the surface offset controls the southern limit of continuous permafrost, which, in Canada, follows treeline. The physical basis for this relation is the change in snow depth across treeline in winter.

\subsubsection{The $\boldsymbol{n}$-factor}

The $\mathrm{n}$-factor represents the ratio of air-to-ground surface temperatures, and was originally designed to summarize the surface energy balance for engineering purposes (Lunardini, 1978). The $\mathrm{n}$-factor is calculated for both the freezing $\left(\mathrm{n}_{\mathrm{f}}\right)$ and thawing $\left(\mathrm{n}_{\mathrm{t}}\right)$ seasons and is determined by the number of freezing and thawing degree-days in the air and at the ground surface:

(2.6a) $n_{t}=\frac{T D D_{s}}{T D D_{a}}$

(2.6b) $n_{f}=\frac{F D D_{s}}{F D D_{a}}$

Where $\mathrm{TDD}_{\mathrm{s}}, \mathrm{FDD}_{\mathrm{s}}$ and $\mathrm{TDD}_{\mathrm{a}}, \mathrm{FDD}_{\mathrm{a}}$ represent thawing and freezing degree-days at the ground surface and in the air. The freezing and thawing seasons may be defined by either air or surface temperatures, but in this thesis the n-factors will be defined using surface temperatures following Karunaratne and Burn (2004), due to the lower variability in this index.

The freezing $\mathrm{n}$-factor is primarily controlled by snow conditions and the amount of latent heat released from the freezing active-layer (Taylor, 1995; Riseborough and 
Smith, 1998). High values of $n_{f}$ generally represent cold winter surfaces with little snow cover (Taylor, 1995). The thawing season $n$-factor is controlled by soil moisture content and site shading (Klene et al., 2001), therefore high values of $n_{t}$ generally represent dry, open sites.

There has been extensive work on the determination of $\mathrm{n}$-factors for different natural surfaces at northern latitudes (Table 2.5; e.g. Jorgenson and Kreig, 1988; Taylor, 1995; Burn, 1998; Klene et al., 2001; Karunaratne and Burn, 2004), however, most of this work has been focussed in the boreal forest and there are limited calculations of nfactors in tundra environments. This thesis provides the opportunity to examine the variability in freezing and thawing n-factors across a transition from boreal forest to low shrub tundra in the Mackenzie Delta region.

\subsubsection{The thermal offset}

The thermal offset is defined as the difference between the annual mean surface temperature $\left(T_{s}\right)$ and the annual mean temperature at the top of permafrost $\left(T_{p}\right)$ (Figure 2.5; Burn and Smith, 1988; Williams and Smith, 1989; Romanovsky and Osterkamp, 1995). The thermal offset exists because of the large seasonal variation in thermal properties of the active layer (Romanovsky and Osterkamp, 1995). The result is a decrease in mean annual temperatures within the active layer from the ground surface to the top of permafrost (Figure 2.5; Burn and Smith, 1988; Romanovsky and Osterkamp, 1995). The effect of this thermal offset terminates at the base of the active layer as there is little seasonal change in the thermal properties of the ground below the base of the active layer (Williams and Smith, 1989). 
Table 2.5 Published n-factors and associated site descriptions. Modified from Karunaratne (2002, Table 2.3).

\begin{tabular}{|c|c|c|c|c|}
\hline Site description & Soil conditions & $\mathrm{n}_{\mathrm{f}}$ & $\mathrm{n}_{\mathrm{t}}$ & Reference \\
\hline Open black spruce forest & $\mathrm{GMC}^{*}=50 \%$ & 0.30 & 0.60 & Jorgenson and Kreig, 1988 \\
\hline Low shrub scrub & $\mathrm{GMC}^{*}=40 \%$ & 0.30 & 0.85 & Jorgenson and Kreig, 1988 \\
\hline Tussock bog & $\mathrm{GMC}^{*}=55 \%$ & 0.30 & 0.90 & Jorgenson and Kreig, 1988 \\
\hline Spruce forest, feathermoss & $\begin{array}{l}\text { Lacustrine-eolian } \\
\text { sand }\end{array}$ & 0.43 & 0.66 & Taylor, 1995 \\
\hline $\begin{array}{l}\text { Burned area, open succession } \\
\text { vegetation }\end{array}$ & Silt & 0.36 & 0.48 & Taylor, 1995 \\
\hline $\begin{array}{l}\text { Tall, open spruce and } \\
\text { hardwood forest }\end{array}$ & Silt & 0.48 & 0.74 & Taylor, 1995 \\
\hline $\begin{array}{l}\text { Tall open spruce and } \\
\text { hardwood forest }\end{array}$ & Silt & 0.36 & 0.44 & Taylor, 1995 \\
\hline $\begin{array}{l}\text { Open upland spruce and } \\
\text { hardwood forest }\end{array}$ & Organic and silt & 0.30 & 0.64 & Taylor, 1995 \\
\hline $\begin{array}{l}\text { Open black spruce and } \\
\text { hardwood forest with moss } \\
\text { ground cover }\end{array}$ & Till & 0.13 & 0.34 & Taylor, 1995 \\
\hline $\begin{array}{l}\text { White spruce forest, thin } \\
\text { moss layer }\end{array}$ & Silt & 0.35 & 0.50 & Burn, 1998 \\
\hline $\begin{array}{l}\text { Post forest-fire willow, aspen, } \\
\text { spruce saplings }\end{array}$ & Silt & 0.22 & 0.55 & Burn, 1998 \\
\hline Mature spruce forest & $\begin{array}{l}\text { Glacilacustrine } \\
\text { sediments }\end{array}$ & 0.30 & 0.45 & Karunaratne and Burn, 2004 \\
\hline Mature white spruce forest & Dry, organic rich & 0.44 & 0.58 & Karunaratne and Burn, 2004 \\
\hline Wet non-acidic Coastal Plain & $\begin{array}{l}\text { Histic pergelic } \\
\text { cryosols }\end{array}$ & - & 1.00 & Klene et al., 2001 \\
\hline Shrubland, Northern Foothills & Pergelic cryosols & - & 0.97 & Klene et al., 2001 \\
\hline
\end{tabular}

GMC $=$ Gravimetric moisture content 
The thermal conductivity of the active layer is generally lower in summer than in winter, because the thermal conductivity of soil pore water is four times less than that of pore ice (Riseborough and Smith, 2002). The low thermal conductivity in summer helps to maintain permafrost, even though surface temperatures increase. During winter, when the thermal conductivity of the ground is high, if the flux of heat out of the ground is high, temperatures at the top of permafrost may drop significantly (Burn, 2004). The magnitude of the thermal offset depends on the ratio of the frozen to thawed thermal conductivities of the ground, and as the ratio increases so does the thermal offset (Romanovsky and Osterkamp, 1995). Peat typically has a very high ratio of frozen to thawed conductivities $(\sim 20)$ (Table 2.3 ), for during summer, peat may dry out, and is then primarily composed of air. The effectiveness of peat as a thermal insulator during summer results in steep temperature and vapour pressure gradients, which drive nonconductive heat transfer processes within the active layer (Hinkel and Outcalt, 1994). Evaporative cooling may occur at depth within peaty soils and reduce the amount of energy being directed towards the ground heat flux, thereby reducing soil warming (Hinkel and Outcalt, 1994). During fall, an increase in precipitation and a reduction in evaporation allow peat to become wetter. Upon freezing, the peat has a high thermal conductivity, due to its high water content. Where there is little seasonal difference in the thermal conductivities of the ground, the thermal offset is small (Romanovsky and Osterkamp, 1995). As the ratio of frozen to thawed conductivities increases, mean annual temperatures decline down to the depth at which the property change takes place (Williams and Smith, 1989). Table 2.4 presents published thermal offsets from Yukon Territory and the Alaskan Coastal Plain. 
The majority of mean annual temperature change in the active layer occurs close to the surface, where the temperature gradient is greatest (Figure 2.8; Romanovsky and Osterkamp, 1995). Below the active layer, mean annual temperatures increase slightly with depth, but the rate of change with depth is small compared to the change within the active layer itself (Burn and Smith, 1988). Romanovsky and Osterkamp (1995) report an increase in the thermal offset with an increase in the depth of the active layer. 


\section{Chapter 3}

\section{Study area and methods}

\subsection{Introduction}

This study investigates the variations in near-surface ground temperatures across the forest-tundra transition zone in the uplands east of the Mackenzie Delta. Detailed measurements of air and ground temperatures, vegetation, and snow conditions were made at six sites between Inuvik and Swimming Point (Figure 3.1). Air and ground temperatures were monitored for one year, and vegetation was classified according to its height and structural complexity. Snow depths were measured at the end of winter 20042005 , and soil properties were described during summer 2005. This chapter describes the location and physical characteristics of the study area and specific study sites.

\subsection{Inuvik - Swimming Point Treeline Transect}

\subsubsection{Location and geomorphic setting}

The study area lies within both the Taiga Plains ecozone and the Southern Arctic ecozone. Six sites were selected along a $90-\mathrm{km}$ north-south transect crossing treeline (Table 3.1; Figure 3.1), and these sites represent conditions grading from boreal forest to tundra. All six are at flat upland locations to limit the difference between the sites due to topographic setting. 


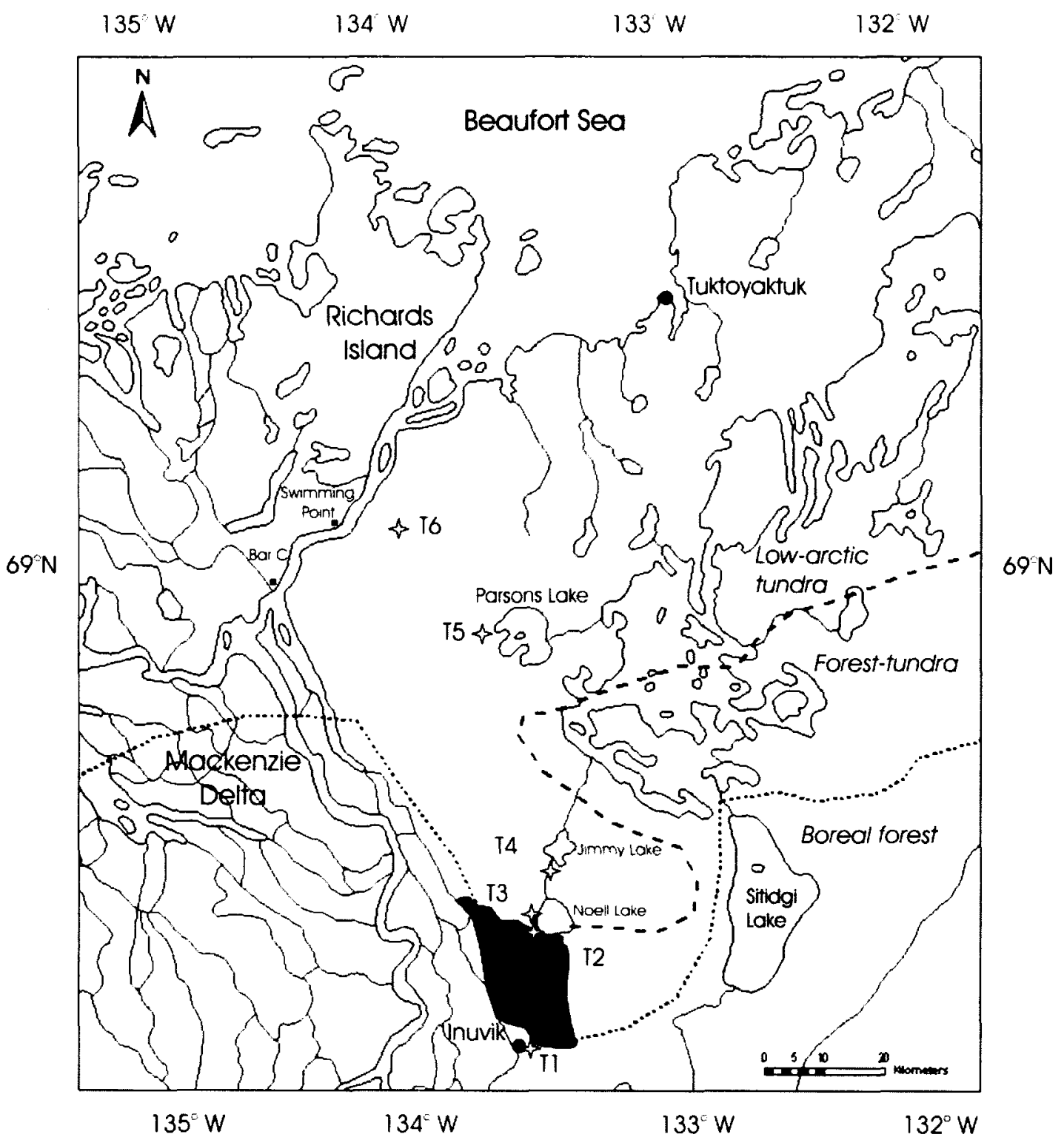

Figure 3.1 Map of the study area. Based on Rampton (1988) and Landhausser and Wein (1993). Study sites are marked by yellow star symbols. The extent of the 1968 foresttundra fire is marked in green. The southern limit of the low arctic tundra is marked by bold dashed line. The northern limit of the boreal forest is marked by the dotted line. 
Table 3.1 Coordinates for the six study sites along the treeline transect.

\begin{tabular}{cccc}
\hline Site & Latitude & Longitude & Distance from T1 (km) \\
\hline T1 & $68^{\circ} 21^{\prime} 44^{\prime \prime} \mathrm{N}$ & $133^{\circ} 42^{\prime} 16^{\prime \prime} \mathrm{W}$ & - \\
T2 & $68^{\circ} 30^{\prime} 51^{\prime \prime N}$ & $133^{\circ} 39^{\prime} 08^{\prime \prime} \mathrm{W}$ & 17.1 \\
T3 & $68^{\circ} 32^{\prime} 15^{\prime \prime} \mathrm{N}$ & $133^{\circ} 39^{\prime} 28^{\prime \prime} \mathrm{W}$ & 19.6 \\
T4 & $68^{\circ} 36^{\prime} 26^{\prime \prime} \mathrm{N}$ & $133^{\circ} 34^{\prime} 52^{\prime \prime} \mathrm{W}$ & 27.8 \\
T5 & $68^{\circ} 57^{\prime} 31^{\prime \prime} \mathrm{N}$ & $133^{\circ} 50^{\prime} 15^{\prime \prime} \mathrm{W}$ & 66.8 \\
T6 & $69^{\circ} 07^{\prime} 04^{\prime \prime} \mathrm{N}$ & $134^{\circ} 10^{\prime} 59^{\prime \prime} \mathrm{W}$ & 86.5 \\
\hline
\end{tabular}


The surficial materials in the study area are composed of a thick wedge of Pleistocene marine and fluvial sediments, capped by a thin glacial till several meters thick (Rampton, 1988). Rampton (1988) suggests that the Wisconsinan Buckland glaciation covered all of the study area and most of the western Arctic east of the Richardson Mountains, depositing fine-grained tills, which cover much of the present landscape. Cretaceous and Tertiary bedrock underlies the Quaternary sediments and contains widespread oil and gas reserves (Rampton, 1988).

The study transect crosses two major geomorphic zones described by Mackay (1963) and later by Rampton (1988) (Figure 3.2). The southern end of the transect, including sites T1 through T4, lies in the South Caribou Hills of the Anderson Plain physiographic region. The South Caribou Hills is a broad upland range standing above the Mackenzie Delta and the Tuktoyaktuk Coastlands. The outer perimeter of the South Caribou Hills is composed of bedrock escarpments, but the interior portion is composed of poorly drained, sloping and hummocky terrain (Rampton, 1988).

T5 is located in the Parsons Lake Plain, part of the Tuktoyaktuk Coastlands physiographic region, separating the southwestern end of the Tuktoyaktuk Peninsula from the South Caribou Hills. It is a poorly drained plain, which slopes eastward towards Parsons Lake and is underlain by a complex of morainal, glaciofluvial, and lacustrine deposits (Rampton, 1988).

The northern end of the transect, including site T6, lies within the Tununuk Low Hills, another subdivision of the Tuktoyaktuk Coastlands physiographic region (Figure 3.2). The Tununuk Low Hills are composed of thick, unconsolidated sediments with textures ranging from clay to sandy gravel (Rampton, 1988). The rolling topography is 


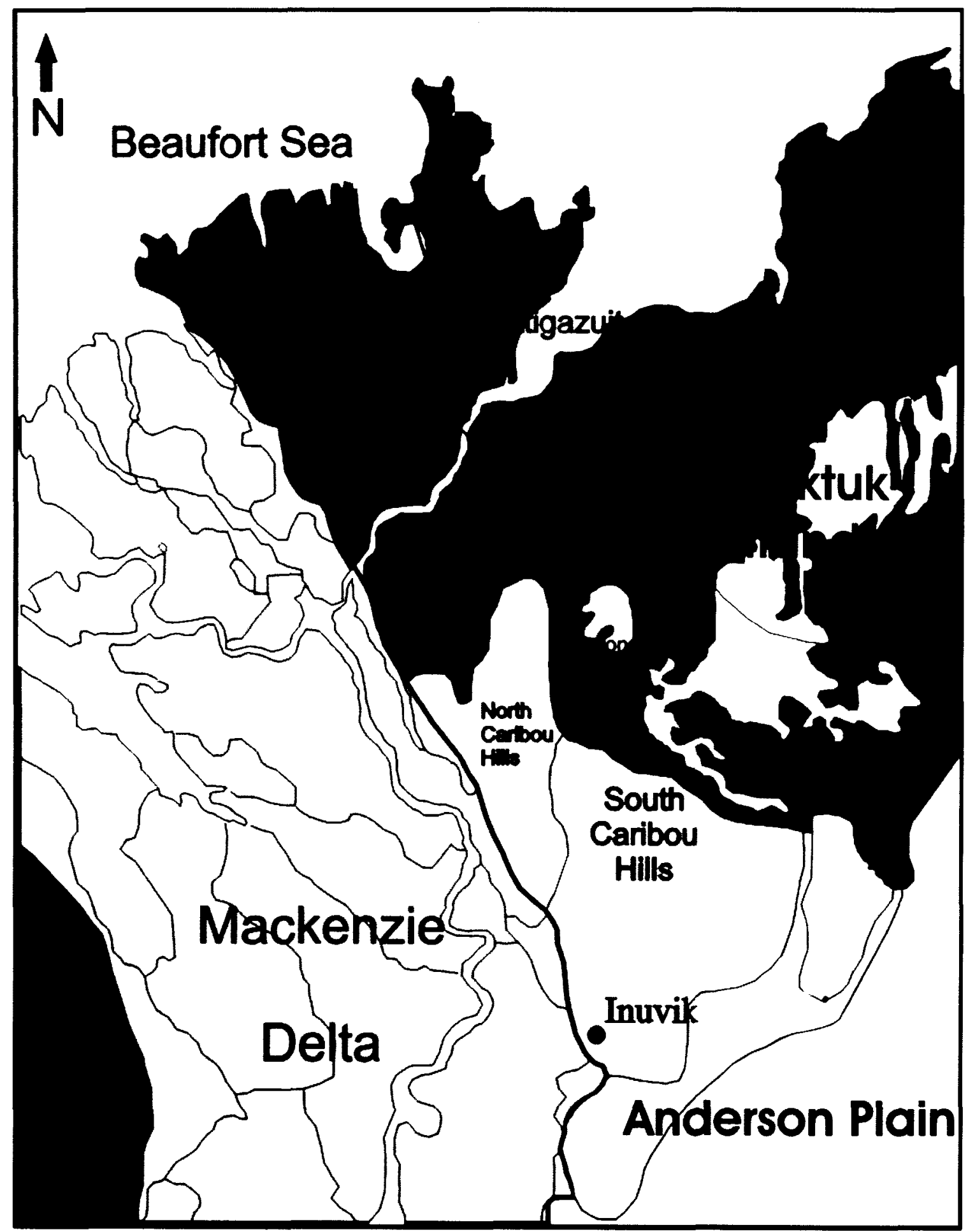

Figure 3.2 Subdivisions of the Tuktoyaktuk Coastlands and Anderson Plain physiographic regions. Based on Rampton (1988, Figure 1). 
characterized by broad, poorly-drained depressions, and a myriad of small lakes (Mackay, 1963; Rampton, 1988). Pingos, exposures of massive ice, and retrogressive thaw slumps are all common in the Tununuk Low Hills (Rampton, 1988).

\subsubsection{Climate}

The climate of the Western Arctic is characterized by long, cold winters and short, cool summers. Precipitation is relatively low and the majority of precipitation falls as rain in late summer or early fall.

At Inuvik, at the southern end of the transect, the mean annual air temperature is $-8.8^{\circ} \mathrm{C}$ (Environment Canada, 2004). The warmest month is typically July $\left(14.2^{\circ} \mathrm{C}\right)$, and the mean summer air temperature (June to September) is $12.0^{\circ} \mathrm{C}$. The coldest month is typically January (Figure 3.3). Almost half of the total precipitation at Inuvik falls between June and September (Figure 3.3). Winter precipitation generally arrives as snow in November and December in several large storms and the snow pack persists throughout the winter.

Tuktoyaktuk is located on the Beaufort Sea coast and is the closest community to the northern end of the transect (Figure 3.1). Precipitation is less at Tuktoyaktuk than at Inuvik, but, as at Inuvik, almost half of the precipitation falls as rain in the late summer and early fall (Figure 3.3). The mean annual air temperature at Tuktoyaktuk $\left(-10.6^{\circ} \mathrm{C}\right)$ is cooler than at Inuvik, mostly due to cooler summers (Figure 3.3). The cooler summer at Tuktoyaktuk is due to onshore winds blowing from the offshore ice pack (Burn, 1997) (Figure 3.3). The summer air temperature difference persists through August, and 
Ilinminl 
disappears when temperatures begin to cool again in September. There is relatively little difference in winter air temperatures between Inuvik and Tuktoyaktuk, as the coastal effect is absent during ice-covered periods (Burn, 1997).

\subsubsection{Present characteristics of treeline near Inuvik}

For the purpose of this study, the forest-tundra transition near Inuvik can be divided into four main ecological groups: 1) an open boreal woodland immediately surrounding Inuvik; 2) a tall shrub zone, which was burned in 1968; 3) a shrubby tussock tundra zone; and 4) a low-shrub tundra zone. The present forest-tundra transition near Inuvik spans approximately $10-15 \mathrm{~km}$ from open boreal woodland to low-shrub tundra (Landhausser and Wein, 1993).

The predominant tree type in the open boreal woodland surrounding Inuvik is black spruce (Picea mariana) (Ritchie, 1984). Tree densities are lower than in southern boreal forests, with approximately 1330 trees / ha, compared to $>8000$ trees / ha at more southerly locations (Ritchie, 1984). The trees are stunted, ranging in height from 2 to 7 m (Ritchie, 1984). A shrub layer of green alder (Alnus crispa), willow (Salix spp.) and dwarf birch (Betula glandulosa) is scattered underneath the open canopy throughout the forest (Ritchie, 1984). Ground cover is composed of a thick mat of a variety of mosses and lichens, including Cladonia spp., Aulacomnium turgidum, and Hylocomium alaskanum, as well as mountain cranberry (Vaccinium vitis-idaea), crowberry (Empetrum nigrum), Labrador tea (Ledum palustre), horsetail (Equisetum spp.), and sweet coltsfoot (Petasites frigidus) (Ritchie, 1984). 
Between 8 and 18 August 1968, an intense fire burned a $500 \mathrm{~km}^{2}$ area of the forest-tundra north and east of Inuvik (Figure 3.1; Landhausser and Wein, 1993; Mackay, 1995). The fire limit is visible along the study transect, midway along the west side of Noell Lake (Figure 3.4). The intense, deep burning consumed the organic layer and exposed mineral soil (Mackay, 1995), and as a result vascular plant biomass is more than double in the burned areas (Landhausser and Wein, 1993). In the burned tundra area, tall (1-3 m) willow, green alder, and dwarf birch shrubs are now the dominant plant species (Landhausser and Wein, 1993). These deciduous shrub species are effective in invading previously treeless areas because they produce viable seeds at an early stage and have an ability for long-range seed dispersal, as opposed to spruce species which have short-range seed dispersal and lack viable seeds near their northern limit (Landhausser and Wein, 1993). The understorey is composed of Labrador tea, mountain cranberry, wild rose (Rosa acicularis) and sweet coltsfoot, and has not fully recovered to pre-fire composition, possibly due to increased shading from the deciduous canopy (Landhausser and Wein, 1993). Hummocks are poorly developed in the area and are difficult to define.

Immediately north of the area burned during the 1968 fire lies an area dominated by grass tussocks, referred to in this study as the shrubby tussock tundra zone. Large green alder shrubs, approximately $1 \mathrm{~m}$ high, are widely spaced throughout the zone. Shorter dwarf birch shrubs are also interspersed throughout the zone. Ground cover is similar to that of the tall shrub zone, but is more abundant than in the tall shrub zone. Hummocks are poorly developed and widely spaced at this site, as the microtopography is dominated by grass tussocks. 
Figure 3.4 Air photo of the west side of Noell Lake. The limit of the 1968 Inuvik foresttundra fire is visible as the contrast between green and grey, slightly north of T2. The fire line in this photograph extends from Noell Lake, east of T2, to the eastern shore of Lake AB. Mackenzie Delta and Valley Airphoto Mapping Program. 2005. Airphoto 1:30,000 [L28-A31866-25]. Yellowknife, NWT: Indian and Northern Affairs Canada. 
The low shrub tundra zone is covered by dwarf shrubs, often in a dense cover closer to the shrubby tussock tundra zone, but more widely spaced at the northern end of the study area (Mackay, 1963). Canopy heights average between 25 and $75 \mathrm{~cm}$ and decrease northward along the transect. Close to the treeline, individual shrubs may reach heights of $2 \mathrm{~m}$ (Mackay, 1963). The area is dominated by dwarf birch, Labrador tea, willow, mountain cranberry, crowberry and bearberry (Arctostaphylos spp.), with a ground cover of abundant mosses and lichens (Cladonia spp., Dicranum spp., and Aulacomnium turgidum) (Ritchie, 1984). Earth hummocks are common and the spatial variation in vegetation at these sites is often due to changes in microtopography associated with hummocks (Ritchie, 1984).

\subsubsection{Permafrost}

The entire study area is located in the continuous permafrost zone, with $>90 \%$ of the terrain underlain by permafrost (Heginbottom et al., 1995). The thickness of permafrost in the area depends on the ground thermal properties and surface temperatures over the last several thousand years (Taylor et al., 2000). Where glacial retreat was early, or the area unglaciated as on northern Richards Island, the thickness of permafrost is greater than in areas where glacial retreat occurred later. Permafrost is generally $>300 \mathrm{~m}$ thick, but the thickness may reach close to $600 \mathrm{~m}$ on the west side of Parsons Lake (Taylor et al., 2000).

The surficial sediments throughout the study area are ice-rich (Nixon, 2000) with ice wedges, massive ice and landscape features such as pingos being common (Mackay, 1963; Rampton, 1988). The high ice content of the sediments in the area results in a 
large amount of thermokarst activity. About $30 \%$ of the area is covered by thermokarst lakes (Rampton, 1988).

A considerable difference in mean annual ground temperature exists across treeline. Ground temperatures south of treeline, in the subarctic boreal forest, are generally higher than ground temperatures north of treeline, in the tundra. Smith et al. (1998) provide an illustration of this difference (Table 3.2). From Inuvik to Parsons Lake, a distance of $60 \mathrm{~km}$ and stretching across treeline, a decrease in annual mean ground temperature of $3.5^{\circ} \mathrm{C}$ was recorded in 1993-1994 (Smith et al., 1998). In comparison, between Inuvik and the Takhini valley, southern Yukon Territory, a distance of $850 \mathrm{~km}$, and both within the subarctic boreal forest, a difference of only $1.5^{\circ} \mathrm{C}$ in annual mean ground temperatures was recorded (Smith et al., 1998).

\subsubsection{Soils}

Turbic cryosol is the dominant soil type in the region (Tarnocai, 2004a). The term cryosol refers to mineral soils where permafrost is present within $2 \mathrm{~m}$ of the surface (Soil Classification Working Group, 1998). Organic or organic-rich mineral horizons are often present near the permafrost table (Tarnocai, 2004b).

The soils in the study area are primarily clays and sandy loam materials with a high moisture content, making them especially susceptible to cryoturbation (Tarnocai, 2004a). The nutrient content of the active layer in cryosols is generally low in relation to other soil types, however the carbon content is generally high, as cryosols may act as carbon sinks (Tarnocai, 2004a). Near-surface permafrost is high in soluble minerals, resulting from the downward migration of ions through the active layer and the 
Table 3.2 Annual mean 100-cm ground temperatures at sites in Takhini Valley, YT, and near Inuvik and Parsons Lake, NWT. Source: Smith et al. (1998, Table 3).

\begin{tabular}{lccc}
\hline \multicolumn{1}{c}{ Location } & $\begin{array}{c}\text { Distance from } \\
\text { Parsons Lake }(\mathbf{k m})\end{array}$ & Study period & $\begin{array}{c}\text { Annual mean } \\
\text { temperature } \\
\left({ }^{\circ} \mathbf{C}\right)\end{array}$ \\
\hline Takhini Valley, YT & & & -1.0 \\
Inuvik, NWT & 910 & Jan 1995 - Jan 1996 & -2.5 \\
Parsons Lake, NWT & 60 & Jan 1993 - Jan 1994 & -6.0 \\
\hline
\end{tabular}


entrapment of soluble materials by a rising frost table at the end of summer (Kokelj and Burn, 2005).

\subsection{Study period}

Air and ground temperatures were measured between September 2004 and September 2005. Ground temperatures within the active layer are interannually variable, so it is important to understand how representative the period was of mean conditions. Air temperature and precipitation normals (1971-2000) from Inuvik and Tuktoyaktuk are compared to air temperature and precipitation data for those locations during the study period in Figs. 3.5 and 3.6.

The mean air temperatures during the study period at both Inuvik $\left(-8.5^{\circ} \mathrm{C}\right)$ and Tuktoyaktuk $\left(-10.5^{\circ} \mathrm{C}\right)$ were similar to climate normals (1971-2000). At both Inuvik and Tuktoyaktuk, January to April was warmer than normal, but the warm winter was offset by a cold period in December and a cool summer. The precipitation totals at Inuvik and Tuktoyaktuk for the study period were $276 \mathrm{~mm}$ and $162 \mathrm{~mm}$, respectively, both within $10 \%$ of normal precipitation totals. Both Inuvik and Tuktoyaktuk had a drier autumn than normal, and less snow fall in the early part of the winter. Large snow falls in January resulted in above normal precipitation totals for the month at both sites. Inuvik also had a relatively wet summer, with above average rain in May and July. 


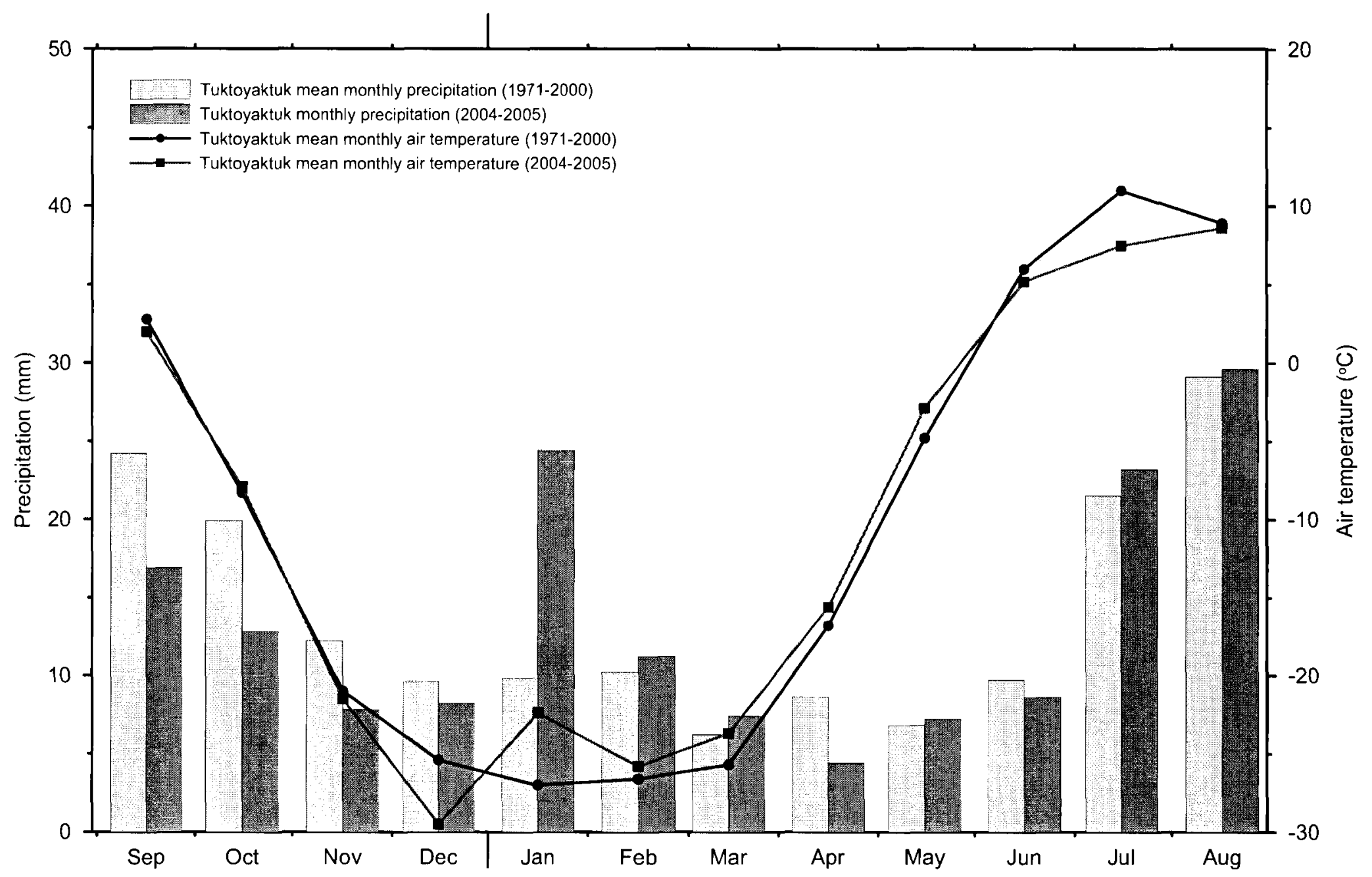

Figure 3.6 Tuktoyaktuk mean monthly air temperatures and monthly precipitation normals (1971-2000)

(Environment Canada, 2004) compared to mean monthly air temperatures and monthly precipitation totals for the study period (2004-2005) (Environment Canada, 2005). 


\subsection{Study design}

The study transect is an ideal location to study the variation in ground temperatures across treeline in the Western Arctic for several reasons. First, the transition between open boreal forest and subarctic tundra is relatively distinct (Landhausser and Wein, 1993). Second, the treeline transition is close to the community of Inuvik, facilitating logistics. The proposed Mackenzie Gas Project pipeline may cross treeline close to the study transect, further highlighting the relevance of the study. Finally, permafrost research in the Inuvik area has been ongoing for over 40 years, which provides a contextual background for the study (Mackay, 1963; Smith, 1975; Smith et al., 1998; Mackay and Burn, 2002, Kokelj and Burn, 2003).

\subsubsection{Site selection}

To investigate the variation in ground temperatures across treeline in the Western Arctic, six research sites labelled $\mathrm{T} 1$ to $\mathrm{T} 6$, were established across the treeline transition near Inuvik, NWT (Figure 3.1). The composition of the vegetation varies considerably along the treeline transect. Vascular and non-vascular plant species were recorded for each site and the list was divided into four functional types: deciduous shrubs, sedges and grasses, forbs, and mosses and lichens. Figure 3.7 presents the estimated percent cover of the functional types at each site. Tree density was only calculated for site $\mathrm{T} 1$, as trees were not present at the other sites. 


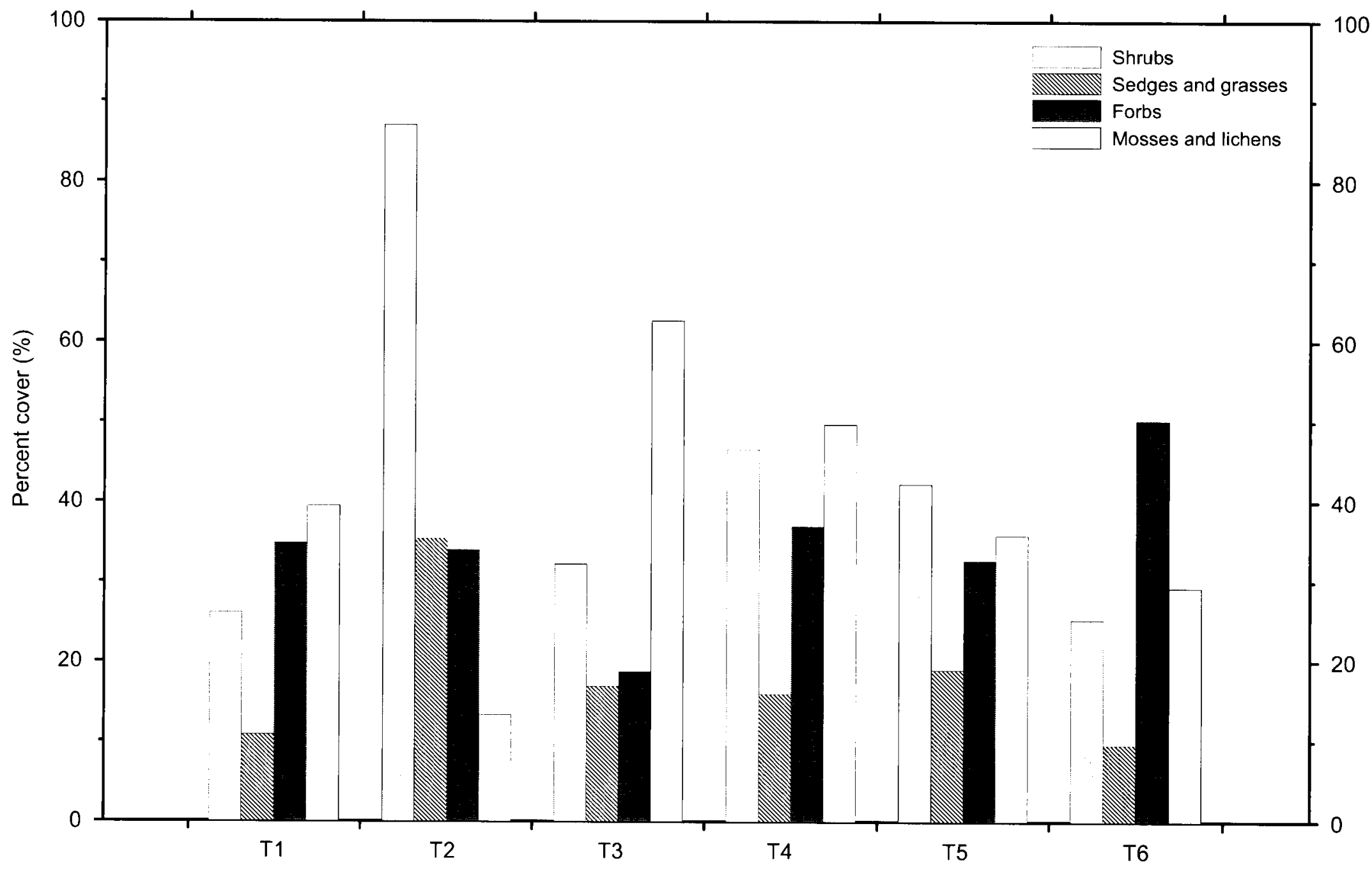

Figure 3.7 Percent cover of functional types at each site. Totals may be $>100 \%$ because plants are at different strata in the site vegetation. 


\subsubsection{T1}

$\mathrm{T} 1$ is located in an open black spruce woodland on a hilltop at the Inuvik ski club (Figure 3.8a). The ground is covered in a thick layer of mosses and lichens and is characterized by widely spaced, well-developed earth hummocks. Tree ( $>3 \mathrm{~m}$ height) density at the site is approximately 1330 trees / ha. The predominant tree species at the site is black spruce, but paper birch (Betula papryifera) are also present. Because of the open nature of the canopy, tall shrubs of dwarf birch and willow cover approximately $28 \%$ of the site, mostly in areas where there are gaps in the canopy cover. Sedges and grasses cover the least amount of area at T1, approximately 10\% (Figure 3.7).

\subsubsection{T2}

$\mathrm{T} 2$ is located approximately $17 \mathrm{~km}$ north of Inuvik and $1 \mathrm{~km}$ west of Noell Lake. The site is within the area burned by the 1968 forest-tundra fire and is populated by tall willow and alder shrubs, up to $3 \mathrm{~m}$ in height (Figure $3.8 \mathrm{~b}$ ). The ground is covered by a very thin organic layer and hummocks are poorly developed at the site. Tall, dense thickets of deciduous shrubs have colonized site T2, since the 1968 fire, and are the predominant functional type, covering approximately $90 \%$ of the site. The ground cover is poorly developed at the site, less than $15 \%$ of the ground is covered in mosses or lichens (Figure 3.7). This is likely due to the dense shrub canopy cover and the relatively recent fire at the site, which consumed the pre-existing organic layer. 


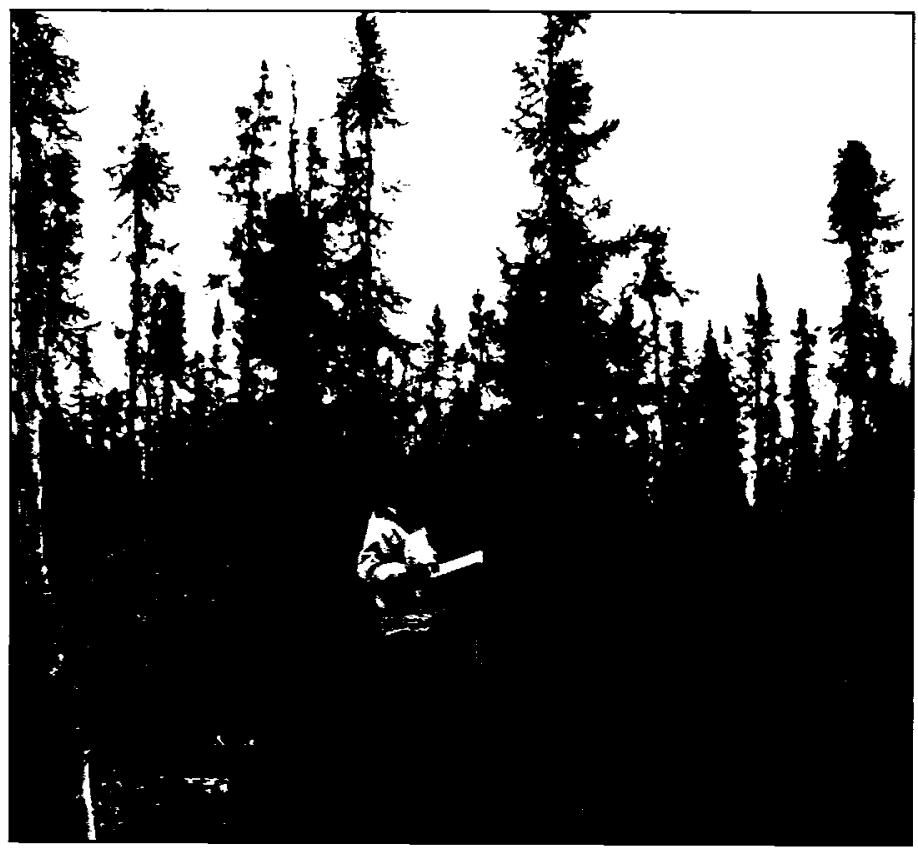

Figure 3.8a Site T1, Inuvik ski club, August 31, 2005.

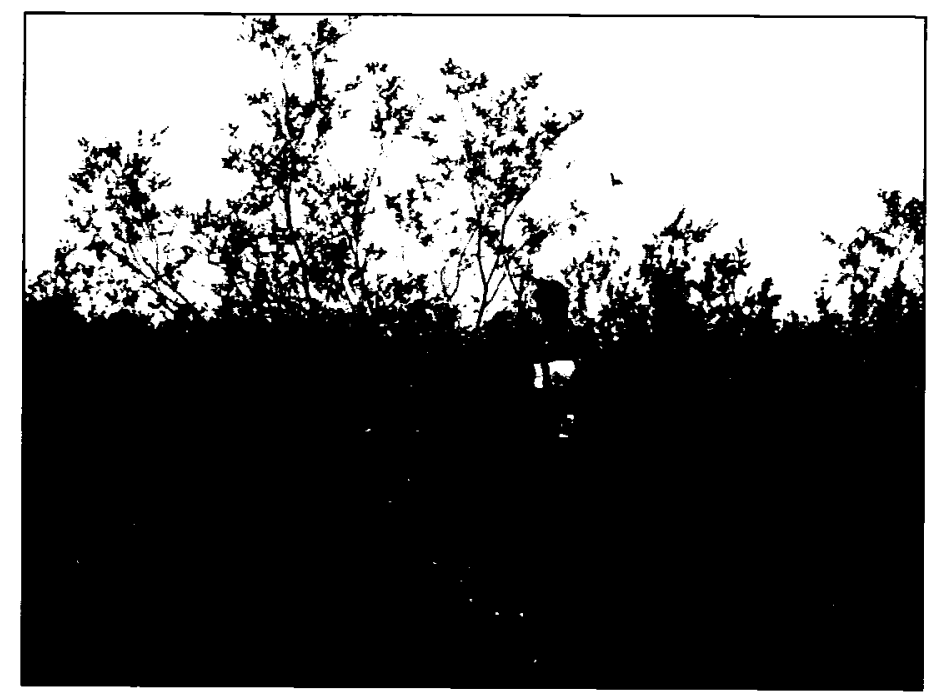

Figure 3.8b Site T2, east of Noell Lake, within the area burned in the 1968 fire, August 18, 2005. 


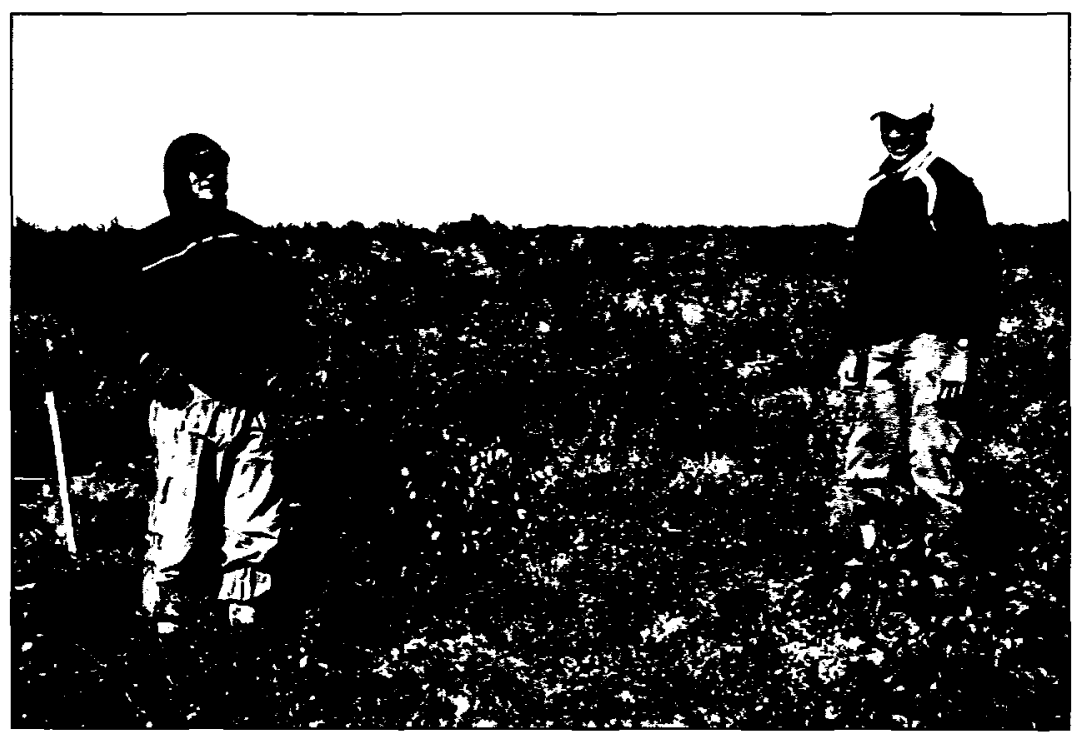

Figure 3.8c Site T3, $1 \mathrm{~km}$ north of the 1968 fire line, east of Noell Lake, August 16, 2005.

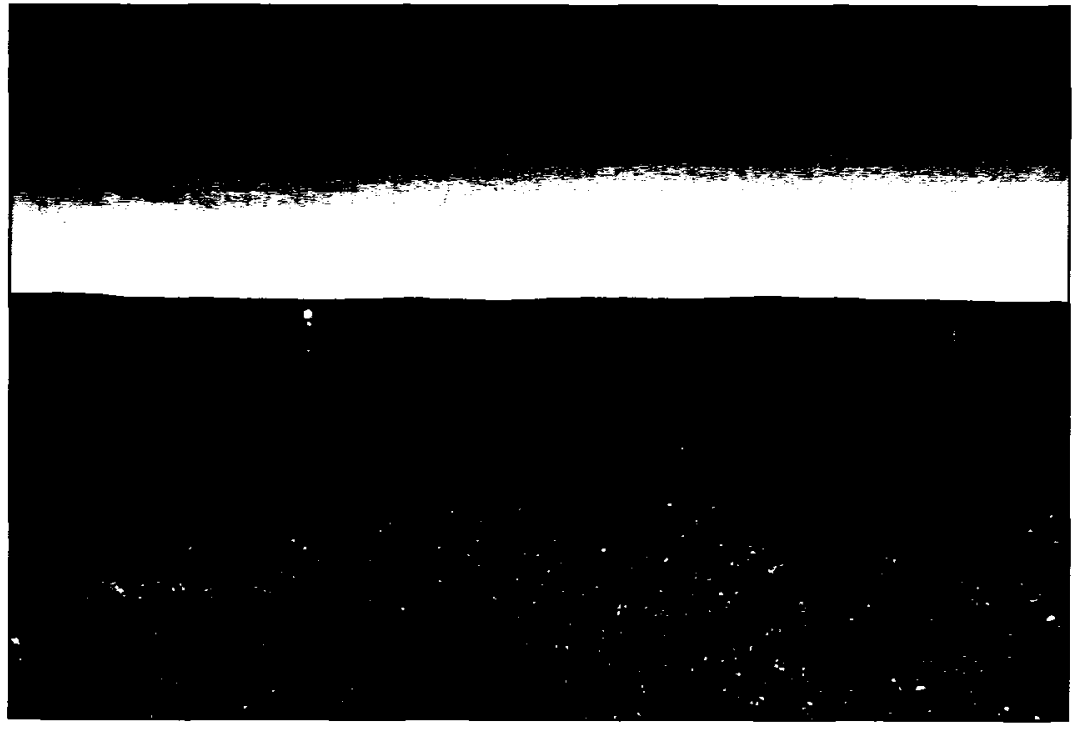

Figure 3.8d Site T4, southeast of Jimmy Lake, August 15, 2005. Air temperature radiation shield is $120 \mathrm{~cm}$ above the ground surface. 


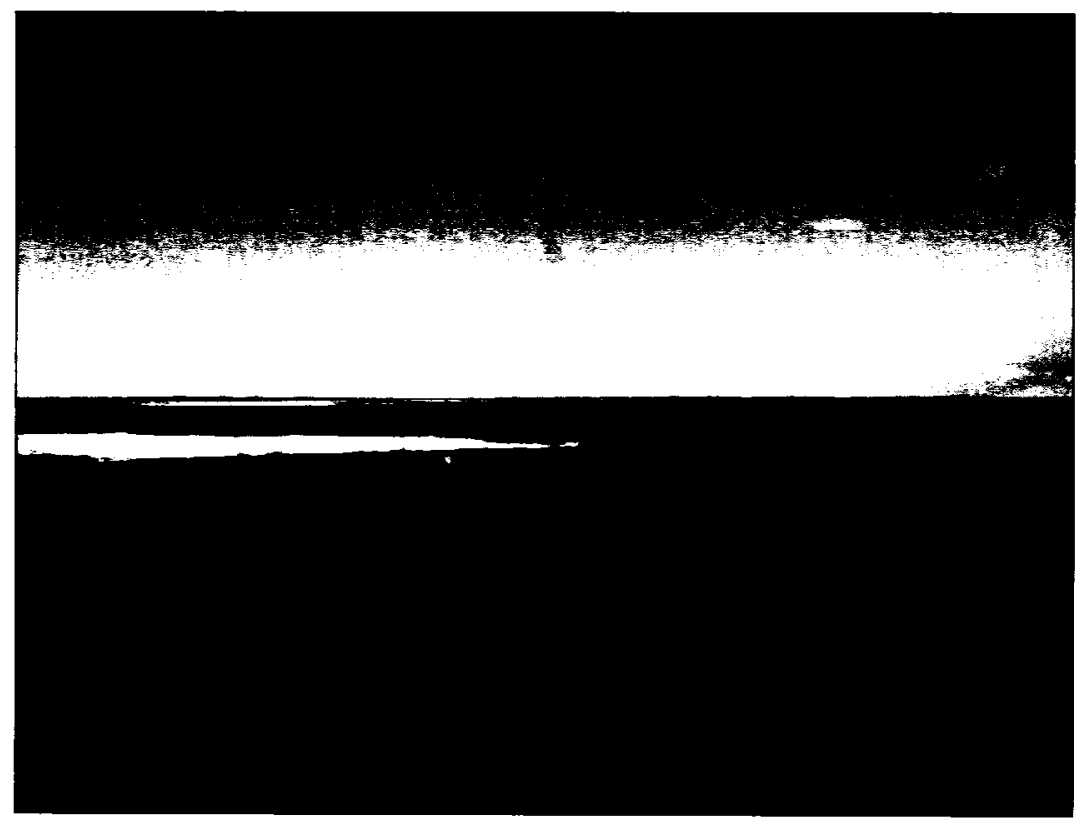

Figure 3.8e Site T5, west of Parsons Lake, August 2005.

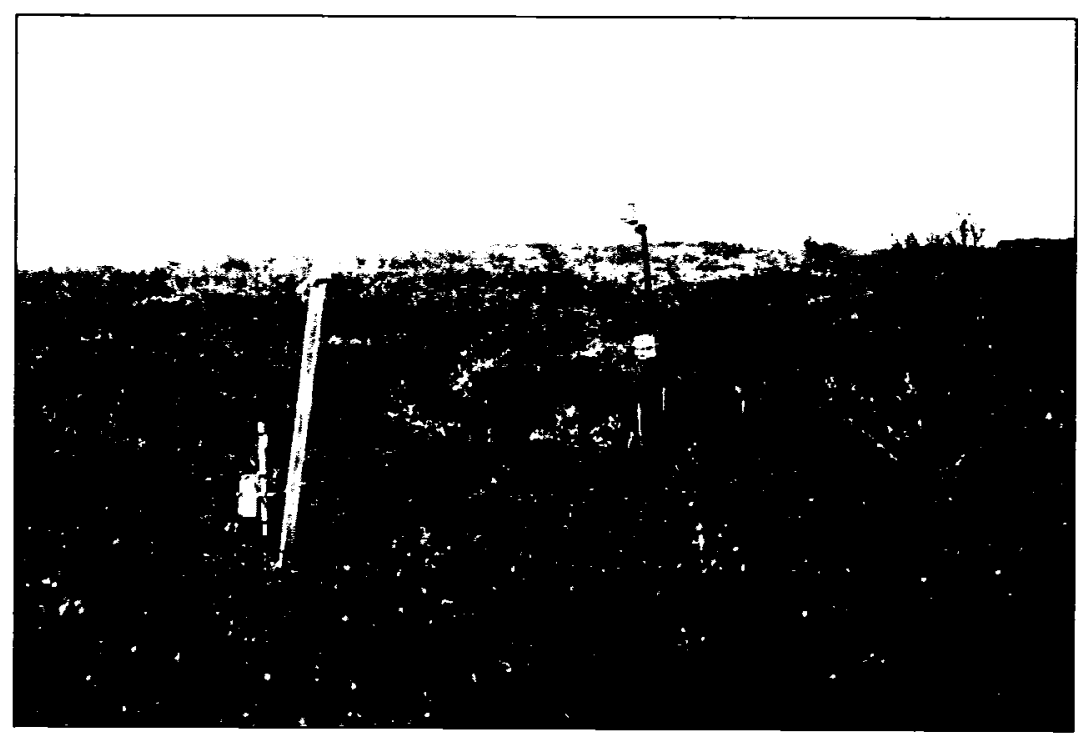

Figure 3.8f Site T6, east of Swimming Point, August 24, 2005. 


\subsubsection{T3}

T3 is located $1.5 \mathrm{~km}$ north of T2 on the other side of the 1968 fire line. The site is characterized by a mix of tussock grasses and large ( $\sim \mathrm{m}$ tall), widely spaced green alders (Figure 3.8c). Hummocks are rare at the site compared to the characteristic grass tussocks. Deciduous shrubs, including green alder, dwarf birch and net vein willow (Salix reticulata) cover approximately $35 \%$ of the site. The moss and lichen ground cover at the site is very well developed and covers approximately $65 \%$ of the site (Figure 3.7).

\subsubsection{T4}

T4 is situated on a hilltop south of Jimmy Lake. The site is covered in a homogeneous, dense layer of low-lying dwarf birch shrubs (Figure 3.8d). Hummocks are well developed at T4 and hummock tops may be $50 \mathrm{~cm}$ higher than adjacent troughs. The hummock tops consist of either a thin organic layer or may be exposed mineral soil. Approximately $50 \%$ of the total area of T4 is covered by deciduous shrubs. The predominant shrub species at the site are dwarf birch and willow. Alder is not present directly at the site, however it is present in the area on the sides of hillslopes and in thaw slumps. Forbs are common at the site and cover approximately $40 \%$ of the site. The ground cover is well developed at the site, approximately $52 \%$ of the ground is covered by mosses and lichens (Figure 3.7). 


\subsubsection{T5}

T5 is located $67 \mathrm{~km}$ from Inuvik on the west shore of Parsons Lake. Hummocks are well developed at the site. Hummock tops have a thin organic horizon, while hummock troughs are organic rich. The site is covered in low-lying dwarf birch and willow shrubs (Figure 3.8e). Deciduous shrubs are the most common functional type at T5 and cover approximately $45 \%$ of the site (Figure 3.7 ). Shrub species present at the site include dwarf birch and several types of willow (Salix alaxensis, S. glauca, $S$. reticulata). T5 is populated by several arctic plant species not found at $\mathrm{T} 4$, including lupin (Lupinus arcticus) and lousewort (Pedicularis arctica).

\subsubsection{T6}

T6 is the end point of the study transect and is located $86 \mathrm{~km}$ from Inuvik, several kilometres to the east of Swimming Point. Hummocks are less well developed at this site compared to T4 and T5, but more developed than T2 and T3. Vegetation at the site is similar to T5, but low-lying alder shrubs are also present (Figure 3.8f). Deciduous shrubs cover approximately $23 \%$ of site T6. Shrub species at the site include alder, dwarf birch, and willow. $50 \%$ of $\mathrm{T} 6$ is covered in forbs, a relatively high percentage in contrast with the rest of the sites (Figure 3.7).

\subsubsection{Air and surface temperature}

All six sites were instrumented in August 2004 with thermistors to measure air and surface temperature (Onset Computing, $\mathrm{HOBO}^{\mathrm{TM}}$, model TMC6-HA). Measurements for both air and surface temperatures were made every 4 hours and recorded with 4-channel $\mathrm{HOBO}^{\mathrm{TM}}$ data loggers (Onset Computing, $\mathrm{HOBO}^{\mathrm{TM}}$, model H08-006-04). The data loggers were housed in water and animal-proof boxes attached to 
a steel pipe. The temperature sensors had a range of $-40^{\circ} \mathrm{C}$ to $100^{\circ} \mathrm{C}$, an accuracy of $+/-$ $0.5^{\circ} \mathrm{C}$ and a precision of $+/-0.41^{\circ} \mathrm{C}$ at $0^{\circ} \mathrm{C}$. When temperatures are increasing and decreasing, the random error (precision) of the instruments is offset over time because measurements will be both above and below the actual value. On an annual scale, the precision of the instruments is also not an issue, because the random error in the mean is reduced by the large number of measurements taken throughout the year (approximately 2190). The accuracy, or systematic error, of the instruments is an issue at all time scales and may bias measurements by $+/-0.5^{\circ} \mathrm{C}$ at $0^{\circ} \mathrm{C}$.

Air temperatures were measured $120 \mathrm{~cm}$ above the ground surface, via a thermistor housed in a radiation shield to protect the sensor from incident radiation and precipitation. Surface temperature was measured $5 \mathrm{~cm}$ below the ground surface in hummock tops, close to the base of the steel pipe. The depth of $5 \mathrm{~cm}$ was used to protect the thermistors from disturbance by local wildlife and to reduce radiative heating. The surface was defined as the ground-air interface. Mosses on the surface were considered part of the ground, not part of the vegetation cover, so when moss was present, thermistors were inserted $5 \mathrm{~cm}$ into the moss.

\subsubsection{Near-surface ground temperature}

Near-surface ground temperatures were recorded to determine the difference in the ground thermal regime between sites across treeline. Annual variation in air temperature and snow and vegetation cover are clearer in the near surface than in deeper ground temperatures, where interannual fluctuations in air temperature, snow cover and vegetation cover may be damped out with depth. Near-surface ground temperatures were 
measured at each site using the same temperature sensors and data loggers used to measure and record air and surface temperatures.

At each site, temperature sensors were attached to a wooden dowel and inserted into a drilled hole in a hummock top, so that the sensors were at intervals of 5,50 , and $100 \mathrm{~cm}$ below the ground surface. A clamp was attached to the bottom of the wooden dowel to prevent heaving of the dowel. The wooden dowels were installed in August 2004 and near-surface ground temperatures were recorded between September 1, 2004 and September 1, 2005.

Temperatures at $100 \mathrm{~cm}$ are considered to record conditions at the top of permafrost. The depth to permafrost varies between the sites, but the $100-\mathrm{cm}$ thermistor was in permafrost at all sites, and there is little variation in annual mean temperature with depth at this point, in comparison with conditions in the active layer (Mackay and MacKay, 1974).

Air and ground temperature data were missing at T3, from August 16, 2005 to the end of the thaw season, due to equipment failure. The missing air, $5 \mathrm{~cm}$ and $50 \mathrm{~cm}$ temperatures were estimated by determining the relation between existing summer temperatures (June 1 to August 15) at T2 and T3, and extrapolating the relation to the end of the thaw season at T3. The relations between summer temperatures at T2 and T3 for air, $5 \mathrm{~cm}$ and $50 \mathrm{~cm}$ were represented by:

(3.1) $\mathrm{T} 3_{\text {air }}=1.01\left(\mathrm{~T} 2_{\text {air }}\right)-0.54\left(\mathrm{r}^{2}=0.96\right.$; standard error of the estimate $\left.=0.31^{\circ} \mathrm{C}\right)$

(3.2) $\mathrm{T} 3_{\text {surfacc }}=1.06\left(\mathrm{~T} 2_{\text {surface }}\right)-1.47\left(\mathrm{r}^{2}=0.94 ;\right.$ standard error of the estimate $=$ $\left.0.62^{\circ} \mathrm{C}\right)$

(3.3) $\quad \mathrm{T} 3_{50}=0.75(\mathrm{~T} 250)-0.46\left(\mathrm{r}^{2}=0.91 ;\right.$ standard error of the estimate $\left.=0.12^{\circ} \mathrm{C}\right)$ 
Missing $\mathrm{T}_{100}$ data at $\mathrm{T} 3$ from August 16 to September 1 was estimated using $\mathrm{T}_{100}$ data from the rest of the sites. $\mathrm{T}_{100}$ was stable and close to $0^{\circ} \mathrm{C}$ at all sites throughout the summer, as temperatures were restricted from warming above $0^{\circ} \mathrm{C}$ by the presence of an ice-rich layer at the top of permafrost, therefore it was assumed that $T_{100}$ at $T 3$ was also stable and close to $0^{\circ} \mathrm{C}$ throughout the summer.

\subsubsection{Vegetation and snow courses}

Vegetation and snow cover were characterized at each site along two 70-m snow courses established in August 2004 (Figure 3.9). The cross-transects were located with GPS, staked with survey laths and oriented NW (SC1) and NE (SC2).

\subsubsection{Vegetation course}

Vegetation at each site was characterized along SC1 to quantify the snowretention capacity of the vegetation during winter and the shading potential of the vegetation cover in summer. Functional type composition at each site was classified using a modified Braun-Blanquet method (Mueller-Dombois and Ellenberg, 2003), mean maximum vegetation height was recorded, and structural complexity of the vegetation canopy at each site was quantified using a LICOR LAI-2000 plant canopy analyzer (LICOR, 1992).

\subsection{Vegetation composition}

The percentage cover of vegetation at the sites was described in August 2005 to investigate the relations between vegetation and summer near-surface ground 


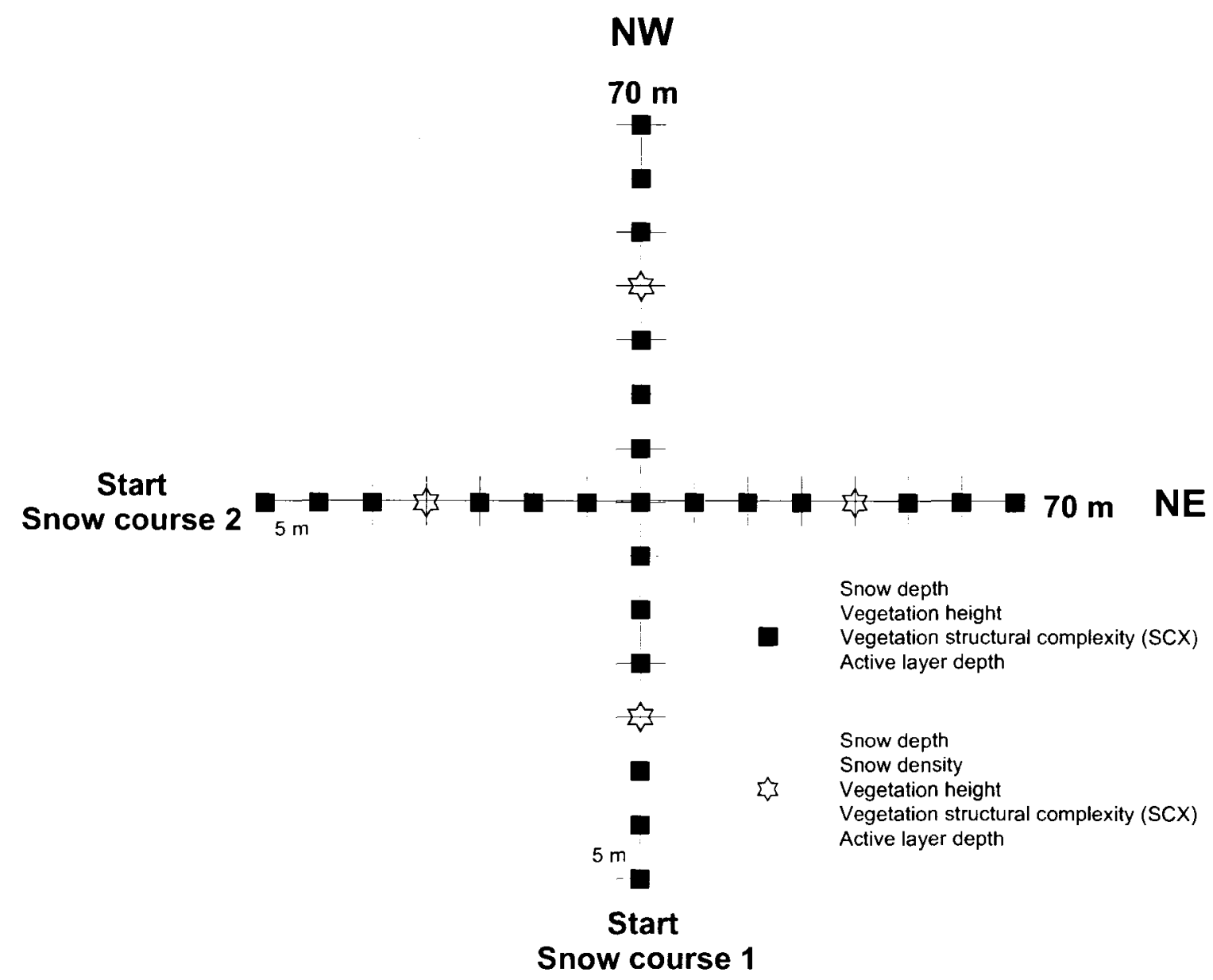

Figure 3.9 Study design for snow and vegetation courses, including measurement locations and variables measured. 
temperatures. Vegetation composition at each site was described using a modified Braun-Blanquet method at 5-m intervals along SC1. A $1-\mathrm{m}^{2}$ grid was placed on the ground at each interval and the percentage cover of vascular and non-vascular plants was recorded. The lists were then grouped according to four functional types: 1) shrubs; 2) sedges and grasses; 3 ) forbs; and 4) mosses and lichens. Where trees over $3 \mathrm{~m}$ high were present at a site, tree density was determined using the point-centered quarter method described by Mueller-Dombois and Ellenberg (2003).

\subsection{Vegetation height}

Vegetation height in this thesis refers to the mean maximum vegetation height of the tallest vegetation within a $1-\mathrm{m}$ radius and was recorded at 5-m intervals along SC1 $(n=15)$. Maximum height refers to the highest point on the vegetation that has the potential to hold snow, and is measured at the vertical limit of foliage on the plant. This eliminates tall but structurally uncomplex parts of the vegetation that will not affect the distribution of snow cover at a site. A 1-m radius was used because vegetation influences more than the immediate area surrounding the plant (Sturm et al., 2005).

\subsection{Structural complexity}

Canopy complexity may be considered a combination of several vegetation properties, including: biomass, cover, height, leaf area index (LAI) and stem area index (Thompson et al., 2004). In this thesis, the objective in determining the structural complexity of the vegetation cover was to estimate the shading of the ground surface during summer. Therefore, a gap fraction technique was used instead of measuring all of 
these vegetation properties. The diffuse non-interceptance (DIFN), or the fraction of the sky that is visible to the LAI sensor through the vegetation canopy, was recorded by the LICOR LAI-2000 at $5 \mathrm{~m}$ intervals along SC1 according to the methodology outlined in LICOR (1992). DIFN may be considered a single-value representation of canopy structure (LICOR, 1992). The fraction of the sky that is blocked by vegetation is equal to 1 - DIFN, and is referred to as SCX, the structural complexity of the canopy.

Because the LAI 2000 plant canopy analyzer measures the diffuse sky radiation at 5 zenith angles simultaneously, the measurement directly above the sensor will be high, but at lower angles radiation will be blocked by surrounding vegetation. The taller the vegetation, the larger the angle required to have an open view of the sky. This is representative of natural shading conditions at a site, as the taller the vegetation, the more light will be intercepted by the canopy when the sun is not directly overhead.

\subsubsection{Snow course}

The insulative properties of the snow cover are primarily a function of the thickness and the density of the snow cover. To determine the influence of snow cover on ground temperatures between sites and to determine the relation between vegetation and snow cover at the sites, snow depth and snow density were measured in March 2005 , towards the end of the 2004/2005 winter season. No measurements were recorded for the early or mid season, thereby limiting our ability to discuss the differences in snow depth between sites throughout the winter, but historically the relative difference in end of month snow depths is similar until the end of March at Inuvik and Tuktoyaktuk (Figure 3.10). 


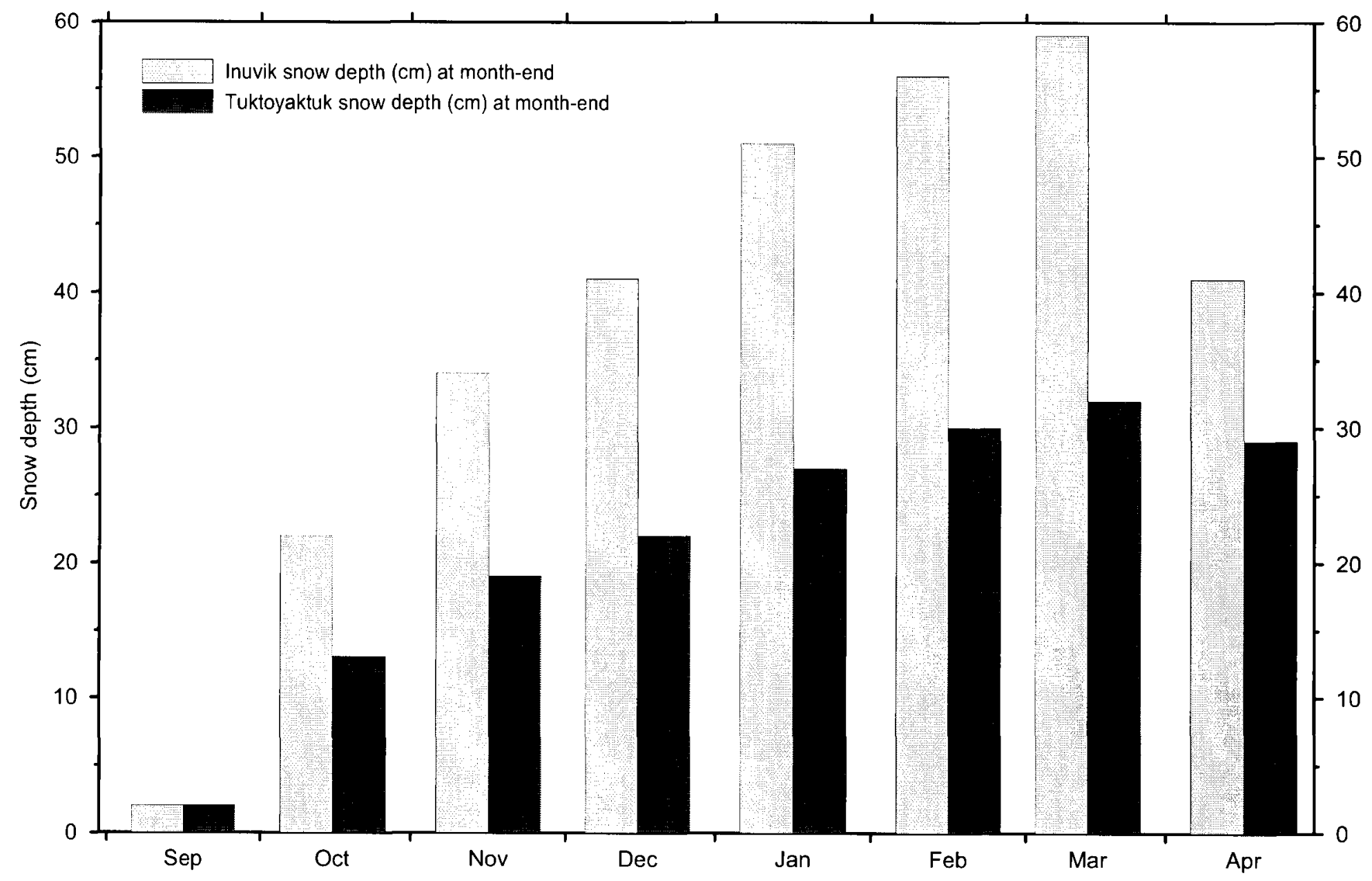

Figure 3.10 Mean snow depth at month end (1971-2000) for Inuvik and Tuktoyaktuk (Environment Canada, 2004). 


\subsection{Snow depth and density}

Snow depths were measured at $5 \mathrm{~m}$ intervals along SC1 and SC2, using a graduated steel rod, for a total of 30 measurements per site. Snow density was recorded at eight locations per site using a Mount Rose graduated snow sampler following the method described by Pomeroy and Gray (1995). The error associated with the Mount Rose sampler is estimated at approximately $10 \%$ (Woo, 1997). Measurements were taken at the starting point of each transect and at each mid point between the junction of the axes and the start of the transects (Figure 3.9). Because snow density varies less than snow depth at a site, fewer measurements of snow density were required (Pomeroy and Gray, 1995).

\subsection{Snow properties}

A snow pit was excavated at each site to investigate the stratigraphy of the snow pack and the difference in snow density throughout the profile. A snow profile was recorded for each snow pit, indicating the thickness and characteristics of each individual layer. Snow density was measured for each stratigraphic layer by weighing a sample of known volume.

\subsubsection{Soil properties}

Soil properties were investigated to estimate the thermal properties of the active layer at each site. A soil pit was excavated to frozen ground at each site between August 13 and August 27, 2005. In hummocky terrain, the soil pit was excavated to include a full hummock top and interhummock trough. Samples of a known volume $\left(216 \mathrm{~cm}^{3}\right)$ 
were taken from the hummock portion of the soil pit at $10-\mathrm{cm}$ intervals from the top of the mineral soil horizon to the base of the active layer. These samples were used to calculate the soil bulk density, gravimetric moisture content, volumetric moisture content, organic content and soil texture at each site. The samples were dried overnight at $105^{\circ} \mathrm{C}$, and the samples were weighed before and after drying to determine the loss of water from the samples.

It must be recognized that measured soil conditions in the active layer depend on whether the soils are extracted from the profile of a hummock top or an interhummock trough. In this study, soil properties of hummock tops were investigated, as ground temperatures were measured within hummock tops at the study sites.

\subsubsection{Active layer}

Thaw depth was measured in mid to late August 2005 to estimate the thickness of the active layer at each site. Thaw depth was measured by inserting a graduated steel probe into the ground to the depth of refusal. Because these measurements were recorded in mid to late August, this depth is considered to be the base of the active layer. Activelayer measurements were made at 5-m intervals along SC1 (Figure 3.9). 


\section{Chapter 4}

\section{Physical characteristics of the study sites}

\subsection{Introduction}

The ground thermal regime is affected by surface and subsurface conditions. This chapter describes the vegetation cover, snow cover, and soil properties along the treeline transect. Specifically this section will examine: (1) variability in the height and structural complexity of the vegetation cover; (2) the properties of the snow cover; (3) the relations between vegetation and snow cover; and (4) variability in soil properties between the research sites along the transect.

\subsection{Vegetation}

The differences in vegetation cover between sites may contribute to variation in the ground thermal regime through differences in snow distribution and shading of the ground surface. The vegetation functional types and species at each site have been discussed in chapter 3 . This section of the thesis describes the change in the structural complexity and height of the vegetation cover across treeline, in addition to discussing the general snow-retention capacity and canopy-shading potential along the forest-tundra transition.

\subsubsection{Vegetation height across treeline}

The snow-retention capacity of vegetation is a combination of the structural complexity and the height of the vegetation cover. However, canopy height is often used 
as a surrogate of canopy complexity, because height closely correlates with roughness length (Thompson et al., 2004). Figure 4.1 shows that structural complexity increases with vegetation height. Spruce trees taller than $3 \mathrm{~m}$ influence the distribution of the snow cover by a different mechanism than deciduous shrubs. Stands of tall spruce trees reduce near-ground wind speeds and limit the redistribution of snow cover in an area, whereas deciduous shrubs physically trap snow within their branch matrices and reduce wind speeds on the lee side of the shrub, resulting in downwind snow accumulation (Pomeroy and Gray, 1995).

On the Alaskan North Slope, Sturm et al. (2001b) also showed that an increase in vegetation height corresponds with an increase in structural complexity. The taller vegetation in the area examined by Sturm et al. (2001b) was generally composed of deciduous shrubs, which were structurally complex and their complexity increased with height. Therefore, vegetation height (VH) is considered to be an effective indicator of snow-retention capacity at a site.

Figure 4.2 indicates that vegetation height generally decreases northward from Inuvik. The tallest vegetation was at $\mathrm{T} 1$, in the open boreal woodland, where mean vegetation height was approximately $290 \mathrm{~cm}$. The shortest vegetation was at T5, $67 \mathrm{~km}$ from Inuvik on the west side of Parsons Lake, with mean vegetation height approximately $35 \mathrm{~cm}$. The greatest differences in canopy height along the transect occur within $27 \mathrm{~km}$ of Inuvik, between sites T1 to T4. The large differences in vegetation height coincide with the change from open boreal woodland at $\mathrm{T} 1$, to tall deciduous shrubs at T2, to shrubby tussock tundra at T3, and finally to shrub tundra at T4. 


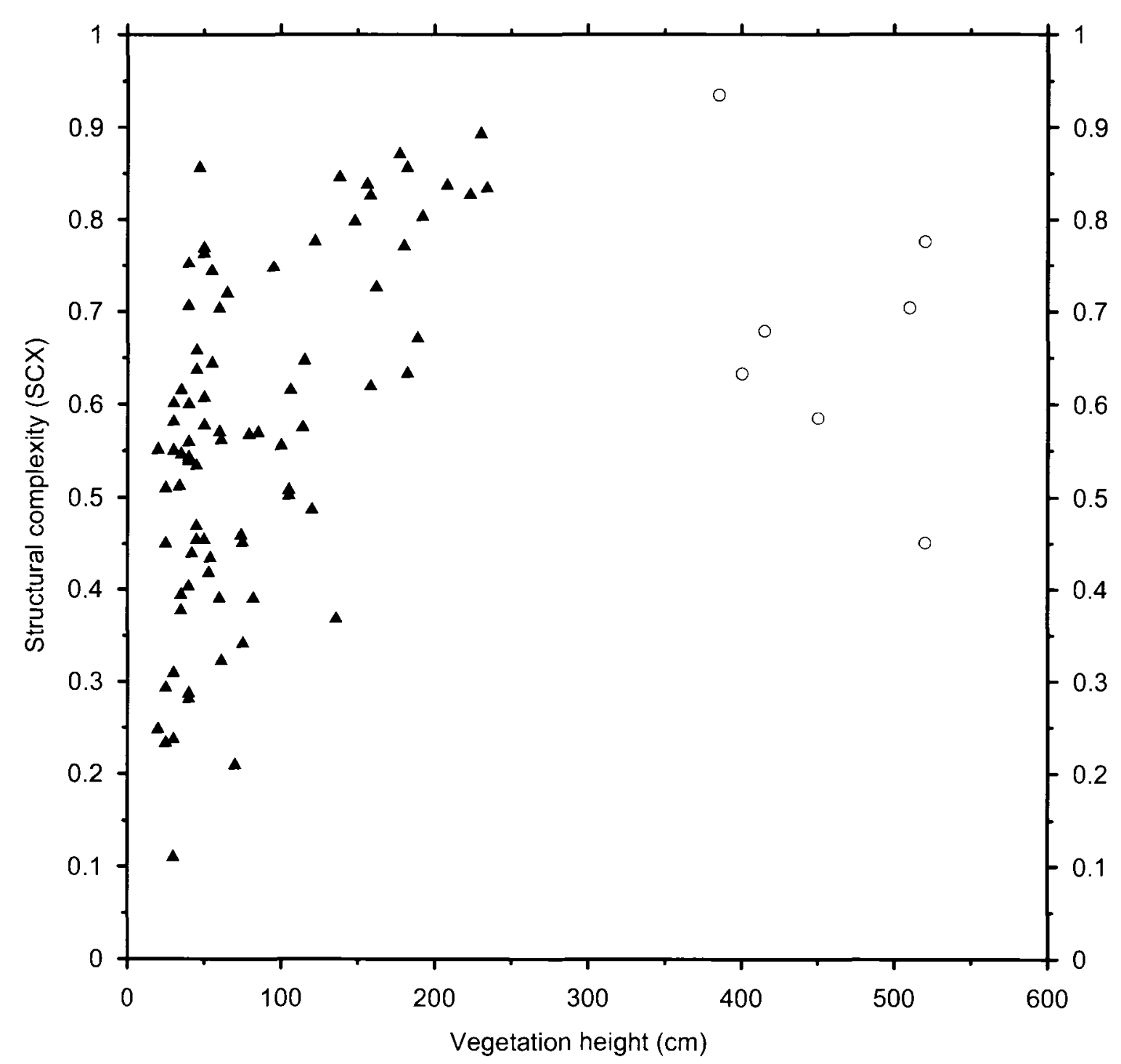

Figure 4.1 Vegetation height (VH) and structural complexity (SCX) along the snow course at sites T1 to T6. The triangles represent VH and SCX, where the vegetation height is less than $300 \mathrm{~cm}$. The circles represent VH and SCX for spruce trees taller than $300 \mathrm{~cm}$ at $\mathrm{T} 1$.

Note: Vegetation height refers to mean maximum vegetation height within 1-m radius of measurement interval (see section 3.4.4.1.2). 


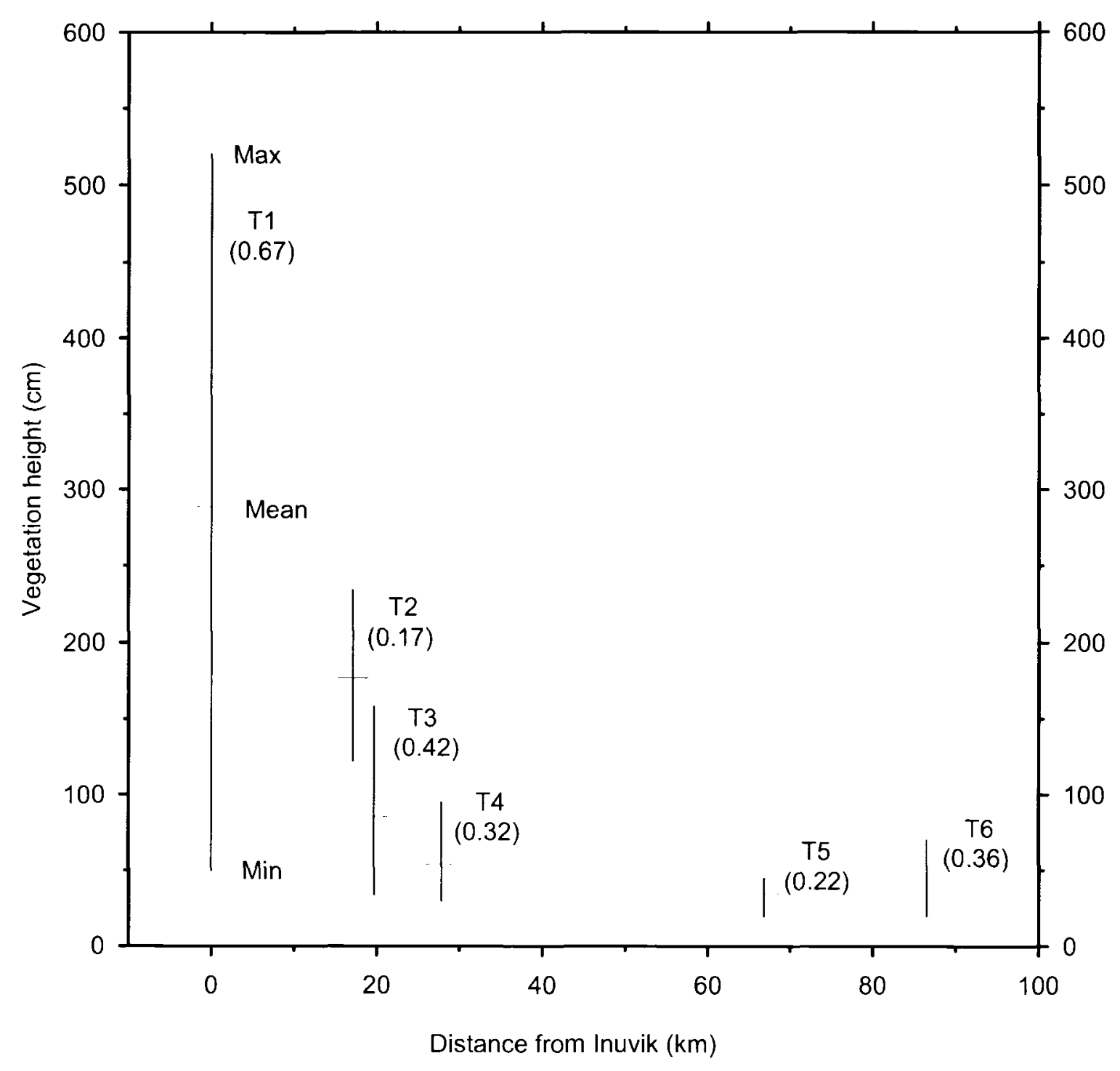

Figure 4.2 Vegetation height ( $\mathrm{VH})$ measured at 15 points along $\mathrm{SC} 1$ at the sites $\mathrm{T} 1$ to T6. The vertical lines are drawn between the maximum and minimum $\mathrm{VH}$ recorded in August, 2005. The ticks indicate the mean VH. Numbers in brackets are the coefficients of variation for $\mathrm{VH}$ at the sites.

Note: Vegetation height refers to mean maximum vegetation height within $1-\mathrm{m}$ radius of measurement interval (see section 3.4.4.1.2). 
Compared to the large change in vegetation height within the first $27 \mathrm{~km}$ of the transect, vegetation height is consistent over the remaining $58 \mathrm{~km}$, between T4 and T6.

A one-way analysis of variance (ANOVA) (Sokal and Rohlf, 1995) was used to investigate variation in vegetation among the six study sites. Vegetation height data was logarithmically transformed to fit the assumptions of the ANOVA (Sokal and Rohlf, 1995). Tamhane's T2 procedure determined differences in mean vegetation height between the sites at the $95 \%$ confidence level (Sokal and Rohlf, 1995). Eleven of the 15 between site comparisons showed significant differences in mean vegetation height (Table 4.1), indicating significant variation in vegetation height along the transect. No significant differences in mean vegetation height were noted between: i) T1 and T2, the open boreal woodland and the tall deciduous shrub site, ii) T3 and T4, the shrubby tussock tundra and the shrub tundra site, iii) T4 and T6, and iv) T5 and T6. The absence of a significant difference in mean vegetation height between T6 and T4 or T5 demonstrates the relative consistency in mean vegetation height at sites north of T4. Mean vegetation heights at both sites south of the shrubline, T1 $(289 \mathrm{~cm})$ and T2 (177 $\mathrm{cm}$ ), are significantly different from all other sites along the transect. The transition from a nearly homogeneous, tall deciduous shrub cover at $\mathrm{T} 2$, to a widely spaced shrub cover at T3, the shrubby tussock tundra site, is a direct result of the 1968 forest-tundra fire. Areas burned during this fire have repopulated with thick, tall stands of deciduous shrubs (Landhausser and Wein, 1993). The northern limit of the 1968 fire creates a sharp 
Table 4.1 Results of the Tamhane T2 post hoc test for the one-way analysis of variance for vegetation height between all six study sites along the treeline transect $(n=15)$. Pvalues $<0.05$, indicating significant difference between sites, are marked in bold.

\begin{tabular}{ccccccc}
\hline & T1 & T2 & T3 & T4 & T5 & T6 \\
\hline T1 & $\mathrm{X}$ & & & & & \\
T2 & 0.998 & $X$ & & & & \\
T3 & $\mathbf{0 . 0 0 7}$ & $<0.001$ & $X$ & & & \\
T4 & $<0.001$ & $<0.001$ & 0.071 & $X$ & & \\
T5 & $<0.001$ & $<0.001$ & $<0.001$ & $\mathbf{0 . 0 0 4}$ & $X$ & \\
T6 & $<0.001$ & $<0.001$ & $<0.001$ & 0.193 & 0.999 & $X$ \\
\hline
\end{tabular}


contrast between the tall deciduous shrub zone and the more open shrubby tussock tundra.

Mean vegetation height at $\mathrm{T} 3(86 \mathrm{~cm})$ is significantly different from mean vegetation height at all sites, except $\mathrm{T} 4(54 \mathrm{~cm}) . \mathrm{T} 3$ is populated with large, widely spaced alders, much shorter and less abundant than those at T2, however, larger and more abundant than at sites north of T4. Mean vegetation height is significantly different between adjacent sites, T4 and T5 $(35 \mathrm{~cm})$, however there is no statistically significant difference at the 0.05 level between T4 and T6 $(40 \mathrm{~cm})$, the most northerly site. Finally, mean VH at T5 is significantly different from all sites except T6, and T6 is significantly different from all sites south of T3 (Table 4.1).

An investigation of the variation in vegetation height at the sites is important as this will influence the homogeneity of the snow cover, which in turn, may influence ground temperatures. The coefficient of variation $(\mathrm{s} / \bar{x})$ is discussed, as opposed to the standard deviation, in order to compare the standardized variation between sites with different means. Within-site variation in vegetation height is greatest at $\mathrm{T} 1$, with a coefficient of variation of 0.64 (Figure 4.2). In the open canopy at T1, some areas at the site are populated by black spruce and paper birch trees several meters tall, while other areas are covered in shorter, low-lying, dwarf-birch shrubs. T2 has a coefficient of variation in vegetation height of 0.17 , the least among the six sites, because the site is densely populated by tall alder and willow shrubs, and there are few open areas. The coefficient of variation is high at $\mathrm{T} 3, \mathrm{~T} 4$, and $\mathrm{T} 6$ because the sites are covered by mixed 
deciduous shrub patches, and open areas, which may be covered by short forbs and lichens.

It is interesting to note that none of the tallest vegetation within the plots at $\mathrm{T} 2$ measured less than $120 \mathrm{~cm}$ high. This is indicative of the dense cover of tall deciduous shrubs at the site. In contrast, the minimum vegetation height for all other sites was between 20 and $50 \mathrm{~cm}$, indicating the open nature of these sites. Minimum vegetation height represents the height of the vegetation in open areas at the sites, characteristically low-lying shrubs and forbs. Because T2 does not have large gaps in the canopy cover, the minimum vegetation height represents the shortest shrubs at T2.

\subsubsection{Vegetation structural complexity across treeline}

Summer shading of the ground surface is represented by the structural complexity (SCX) measurement. Increases in SCX are associated with increased foliage, and increased shading of the ground surface (Beringer et al., 2005). The structural complexity (SCX) of the vegetation cover differs greatly between the sites along the transect (Figure 4.3).

Multiple Mann-Whitney tests using the Bonferonni correction (Sokal and Rohlf, 1995) were used to investigate variation in structural complexity among the six study sites along the treeline transect. Thirteen of the 15 between site comparisons showed significant differences in median vegetation SCX at the $95 \%$ confidence level (Table 4.2), indicating significant variation in vegetation SCX along the treeline transect. 


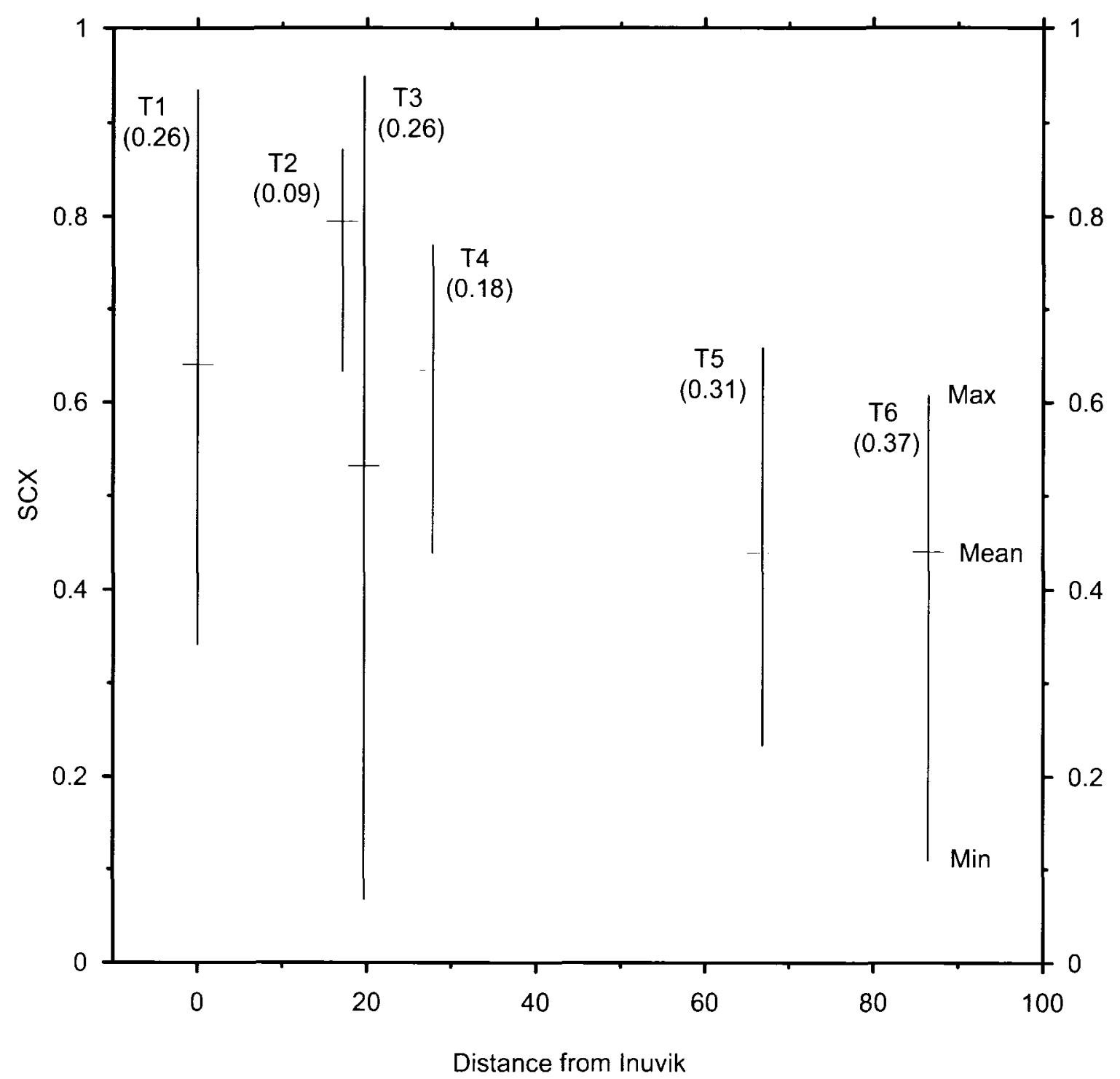

Figure 4.3 Structural complexity $(\mathrm{SCX})$ at sites $\mathrm{T} 1$ to $\mathrm{T} 6(\mathrm{n}=15)$. The vertical lines are drawn between the maximum and minimum SCX values recorded in August, 2005. The ticks indicate the mean values for SCX. Numbers in brackets represent the coefficients of variation. 
Table 4.2 Results from the multiple Mann-Whitney tests for SCX $(n=15)$ between all six study sites along the transect. P-values were adjusted using the Bonferonni correction (Sokal and Rohlf, 1995). P-values $<0.05$, indicating significant difference in median SCX between sites, are indicated in bold.

\begin{tabular}{ccccccc}
\hline & $\mathrm{T} 1$ & $\mathrm{~T} 2$ & $\mathrm{~T} 3$ & $\mathrm{~T} 4$ & $\mathrm{~T} 5$ & $\mathrm{~T} 6$ \\
\hline $\mathrm{T} 1$ & $\mathrm{X}$ & & & & & \\
T2 & $<\mathbf{0 . 0 0 1}$ & $\mathrm{X}$ & & & & \\
T3 & $<\mathbf{0 . 0 0 1}$ & $<\mathbf{0 . 0 0 1}$ & $\mathrm{X}$ & & & \\
T4 & 0.064 & $<\mathbf{0 . 0 0 1}$ & $<\mathbf{0 . 0 0 1}$ & $\mathrm{X}$ & & \\
$\mathrm{T} 5$ & $<\mathbf{0 . 0 0 1}$ & $<\mathbf{0 . 0 0 1}$ & $\mathbf{0 . 0 0 8}$ & $<\mathbf{0 . 0 0 1}$ & $\mathrm{X}$ & \\
$\mathrm{T} 6$ & $<\mathbf{0 . 0 0 1}$ & $<\mathbf{0 . 0 0 1}$ & $\mathbf{0 . 0 2 9}$ & $<\mathbf{0 . 0 0 1}$ & 0.054 & $\mathrm{X}$ \\
\hline
\end{tabular}


Structural complexity measurements at the sites along the treeline transect can be generally divided into two groups. The first group, $\mathrm{T} 1$ to $\mathrm{T} 4$, represents sites of greater vegetation structural complexity (mean 0.52 to 0.85 ), the second group, T5 and T6, represent sites of less structurally complex vegetation (mean approximately 0.44) (Figure 4.3). SCX at T5 and T6 are not significantly different at the 0.05 confidence level ( $P=$ $0.054)$.

Mean SCX is greatest at T2, because the tall, dense, deciduous shrubs at the site are characterized by a complex matrix of branches. When these shrubs are close together in a dense, homogeneous cover, as at $\mathrm{T} 2$, or to a lesser extent at T4, the complex branch matrix extends to cover a larger area, thereby increasing SCX at the site. Mean SCX was also large at T1, the open boreal woodland site, where the tall canopy cover intercepted the incoming diffuse sky radiation when the sun was not directly overhead.

Mean SCX was lowest at T5 and T6, where structurally complex vegetation, such as deciduous shrubs, were rare and widely spaced. Mean SCX at T3 was much lower than the mean SCX at T2 and T4, however, the range in SCX measurements was greater than at any other site. SCX was lower at T3 because the site was located in shrubby tussock tundra with widely spaced complex alders, so SCX values were high only when directly adjacent to or beneath one of the alder shrubs. The variation in SCX is large at T3 because the site is populated by a mix of large complex alders and large open spaces.

The variation in SCX is generally large at all sites (Figure 4.3), because SCX is dependent on whether or not the measurement was made directly beneath a shrub or in 
between shrubs. Variation in SCX was lowest at T2, because there were very few open areas at the site where the ground surface was fully exposed to the sky.

From these data, it appears that summer shading of the ground surface is greater south of $\mathrm{T} 4$, and is greatest at $\mathrm{T} 2$. The ground surfaces at sites north of T4 have more direct exposure to sunlight than those south of T4. This may contribute to differences in summer ground temperatures between the sites. It is important to note that summer shading of the ground surface is only one of the contributing factors to summer nearsurface ground temperatures. Near-surface summer ground temperatures are also dependent on air temperature, soil moisture content, soil bulk density, and the thickness of the organic cover at the site (Burn, 2004).

\subsubsection{Vegetation data - snow courses vs. logger installations}

Vegetation data were collected at each site in two locations: i) along the 70-m snow course oriented northwest (SC1), and ii) within a 3-m radius of the ground temperature installations. Vegetation data were collected at these two locations to determine if vegetation conditions around the ground temperature installations were representative of site conditions, and vice versa.

\subsubsection{Mean vegetation height (MVH)}

Mean vegetation heights along the snow course $(n=15)$ and surrounding the ground temperature loggers $(n=12)$ are presented in Figure 4.4. A series of Student's $t$ tests were performed between the vegetation height data sets at each site to determine if a statistically significant difference exists at the $95 \%$ confidence level between the mean 


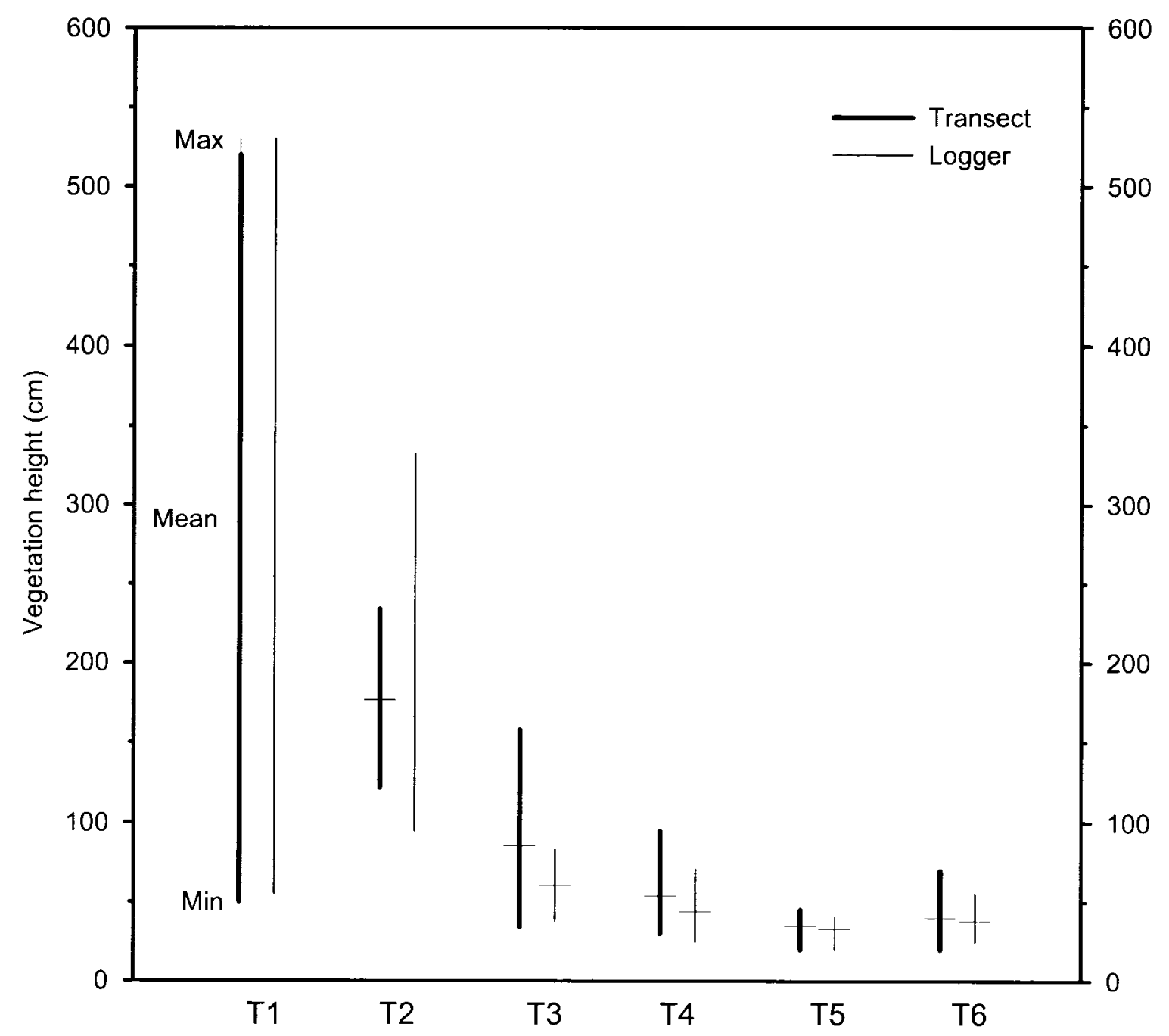

Figure 4.4 Vegetation height along the snow course at each site $(n=15)$ and within a 3$m$ radius of the ground temperature logger $(n=12)$. Horizontal lines represent the mean vegetation height at each location. Vertical lines represent the maximum and minimum vegetation height at the sites. Measurements made in August 2005. 
vegetation heights along the snow course and surrounding the ground temperature installation. The results of the $t$ tests are presented in Table 4.3.

The mean vegetation heights were significantly different only at $\mathrm{T} 3(\mathrm{t}=2.38, \mathrm{P}=$ 0.027). All other comparisons yielded no significant difference between the mean vegetation height along the snow course and surrounding the ground temperature installation at each site (Table 4.3). The rank order of the sites is the same if the sites are ordered by vegetation height along the snow course or vegetation height surrounding the ground temperature installation, therefore, differences in mean vegetation height between the logger and the snow course at T3 will not influence the between site comparison of vegetation heights across treeline.

\subsubsection{Structural complexity (SCX)}

Structural complexity $(\mathrm{SCX})$ measurements along the snow course $(\mathrm{n}=15)$ and surrounding the ground-temperature installations $(n=4)$ are compared in Figure 4.5. The spread in SCX values is generally higher along the snow course than the spread within a $3 \mathrm{~m}$ radius of the ground temperature loggers. This is due to the lower number of SCX measurements taken in the area surrounding the ground temperature logger, and the fact that the variability in structural complexity is less in a smaller area.

A series of Student's t tests and Mann-Whitney U tests were performed between the SCX data at each site to determine if the mean (Student's t) or the median (MannWhitney) SCX was significantly different at the $95 \%$ confidence level between the snow course and surrounding the temperature logger. Student's $t$ tests were used where the data were normally distributed; the Mann-Whitney test was used where the data set did 
Table 4.3 Results from the Student's t tests between mean vegetation height along the vegetation transects $(n=15)$ and within a $3-m$ radius of the ground temperature cable $(n=12)$ at each site. The P-value $<0.05$ is in bold and indicates a significant difference.

\begin{tabular}{lccc}
\hline & \multicolumn{3}{c}{$\begin{array}{c}\text { degrees } \\
\text { of }\end{array}$} \\
& t-stat & $\begin{array}{c}\text { of } \\
\text { freedom }\end{array}$ & p-value \\
\hline T1 & 0.50 & 25 & 0.6206 \\
T2 & 1.09 & 25 & 0.2872 \\
T3 & 2.38 & 21 & $\mathbf{0 . 0 2 6 9}$ \\
T4 & 1.73 & 25 & 0.0965 \\
T5 & 0.75 & 25 & 0.4580 \\
T6 & 0.48 & 22 & 0.6353 \\
\hline
\end{tabular}




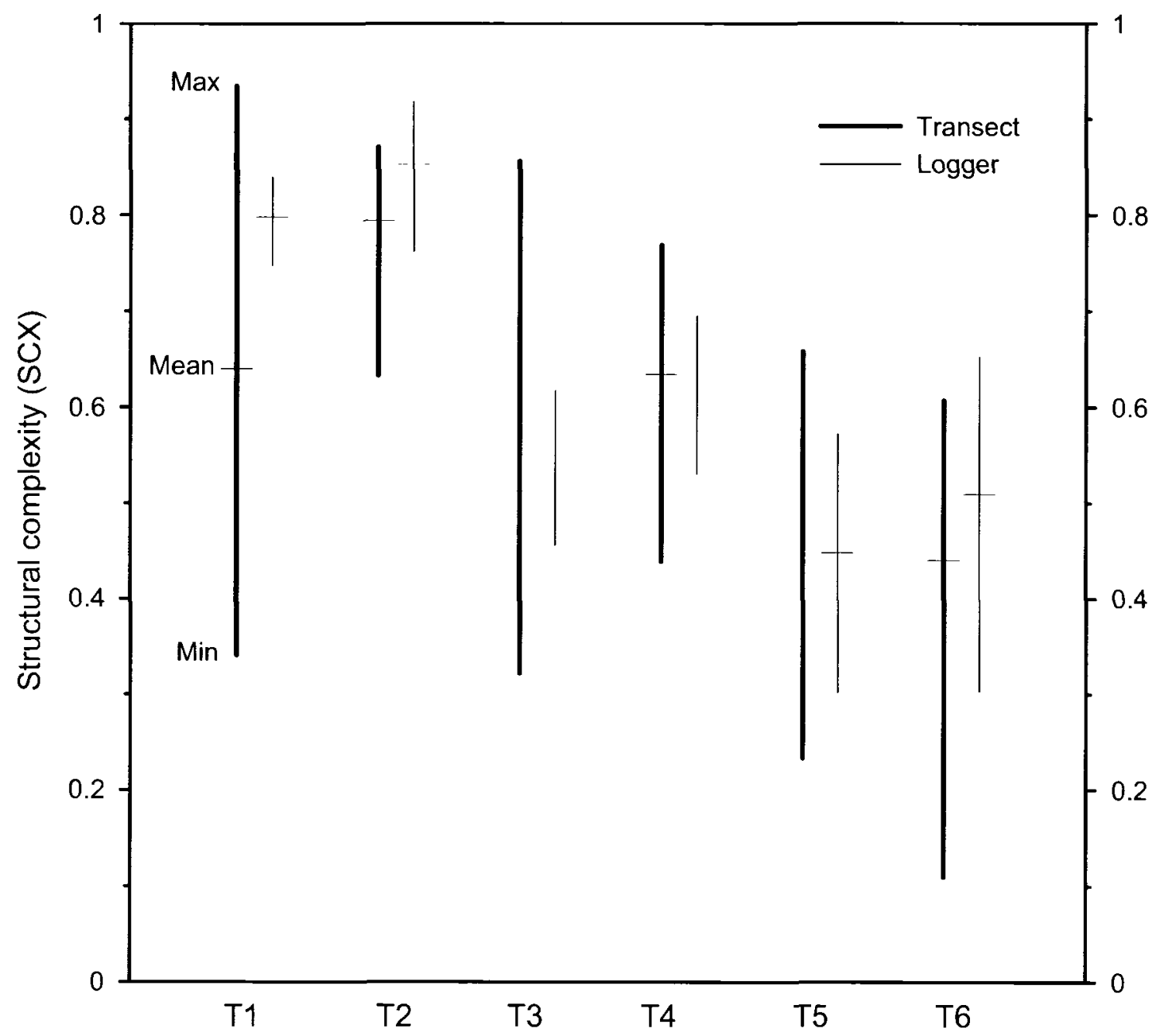

Figure 4.5 SCX measurements along the $70-\mathrm{m}$ snow course $(\mathrm{n}=15)$ and within a $3-\mathrm{m}$ radius of the ground temperature logger dowel $(n=4)$. Horizontal lines represent the mean $\mathrm{SCX}$ value at each location. Vertical lines represent the maximum and minimum extent of SCX at the locations. 
not fit the assumptions of parametric testing (Sokal and Rohlf, 1995). The results of the statistical tests are presented in Table 4.4. There was no significant difference in median SCX between the snow course and the ground temperature loggers for sites T2, T3, T4, T5, and T6.

A significant difference in mean SCX existed at $\mathrm{T} 1$ between the snow course and the area surrounding the ground temperature logger, however, the rank order of T1 versus the other sites is the same for the snow courses and around the ground temperature loggers, therefore, differences in mean SCX at T1 between the logger and the snow course should not influence between site comparisons of SCX.

\subsection{Snow}

\subsubsection{Snow depth across treeline}

Snow depths, measured at the end of March 2005, are presented for each of the sites in Figure 4.6. Mean snow depths decrease with distance from Inuvik, similar to the trend in mean vegetation height (Figure 4.2). A Spearman rank-order correlation between vegetation height and snow depth at all of the measurement sites indicated a significant positive relation between the two variables $(\mathrm{r}=0.683 ; \mathrm{P}<0.001 ; \mathrm{n}=90)$. Figure 4.7 shows the curvilinear relation between vegetation height and snow depth. An increase in snow depth occurs with an increase in vegetation height; the increase in snow depth being the greatest where the vegetation height is between $0 \mathrm{~cm}$ and $100 \mathrm{~cm}$. It appears as though a maximum snow depth is reached between 100 and $150 \mathrm{~cm}$, likely 
Table 4.4 Results from the statistical tests between SCX along the vegetation transects $(\mathrm{n}=15)$ and $\mathrm{SCX}$ within a $3-\mathrm{m}$ radius of the ground temperature logger $(n=4)$ at each site. The P-value $<0.05$ is in bold and indicates a significant difference in the means at $\mathrm{T} 1$.

\begin{tabular}{lccccc}
\hline & \multicolumn{3}{c}{$\begin{array}{c}\text { Mann- } \\
\text { Whitney } \\
\text { t-stat }\end{array}$} & $\begin{array}{c}\text { degrees } \\
\text { Z-stat } \\
\text { of }\end{array}$ & \\
\hline & & & & & \\
freedom & p-value \\
T1 & -3.28 & & & 17 & $\mathbf{0 . 0 0 4 4}$ \\
T2 & & -1.60 & 14.00 & & 0.1100 \\
T3 & & -0.30 & 27.00 & & 0.7640 \\
T4 & & -1.00 & 20.00 & & 0.3170 \\
T5 & & -0.40 & 26.00 & & 0.6890 \\
T6 & & -0.70 & 23.00 & & 0.4840 \\
\hline
\end{tabular}




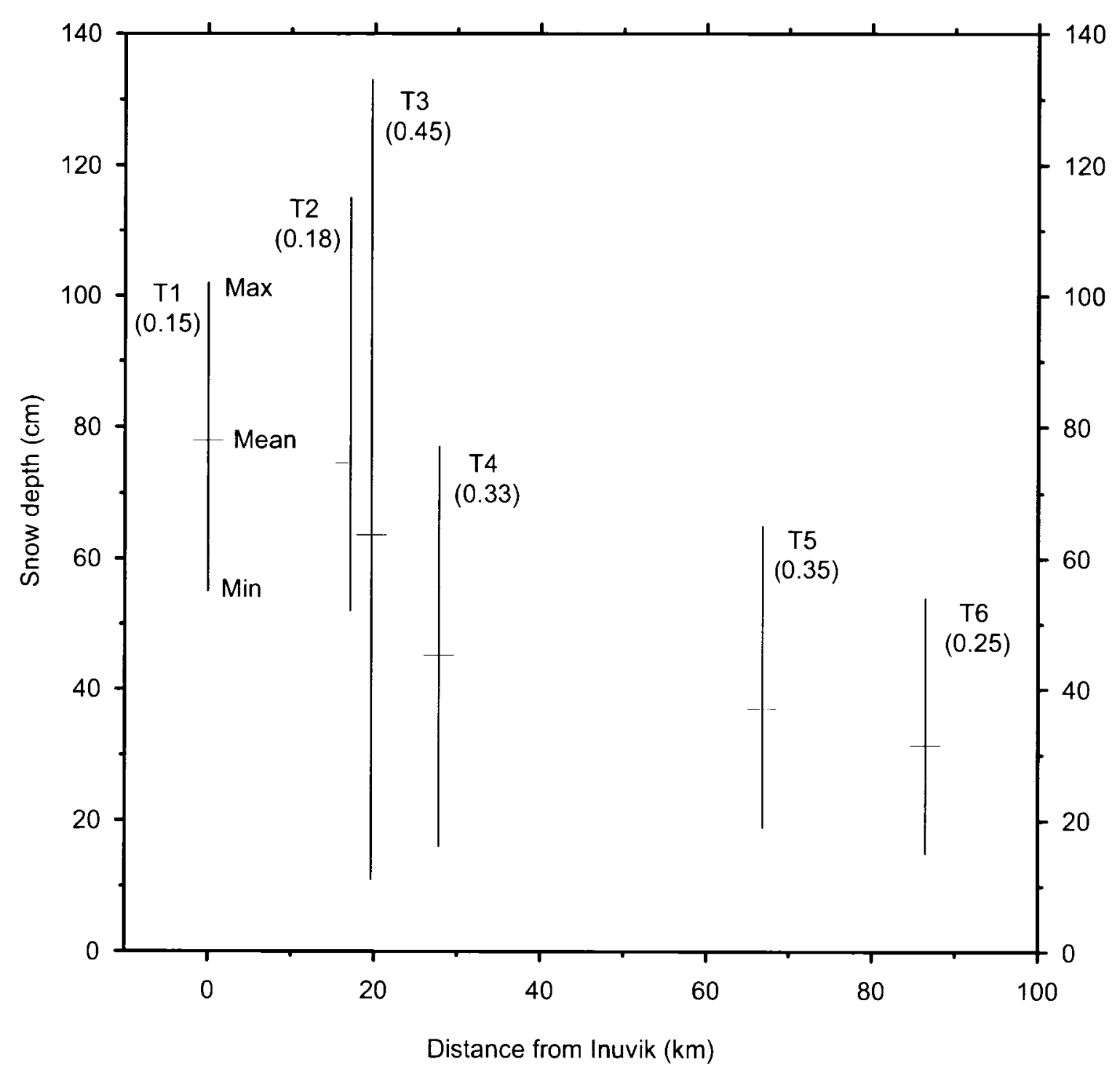

Figure 4.6 Snow depths across treeline, end of March 2005. The horizontal lines represent mean snow depth at each site $(n=30)$. The vertical lines represent the range in snow depths at the site. Numbers in parentheses are the coefficients of variation in snow depth. 


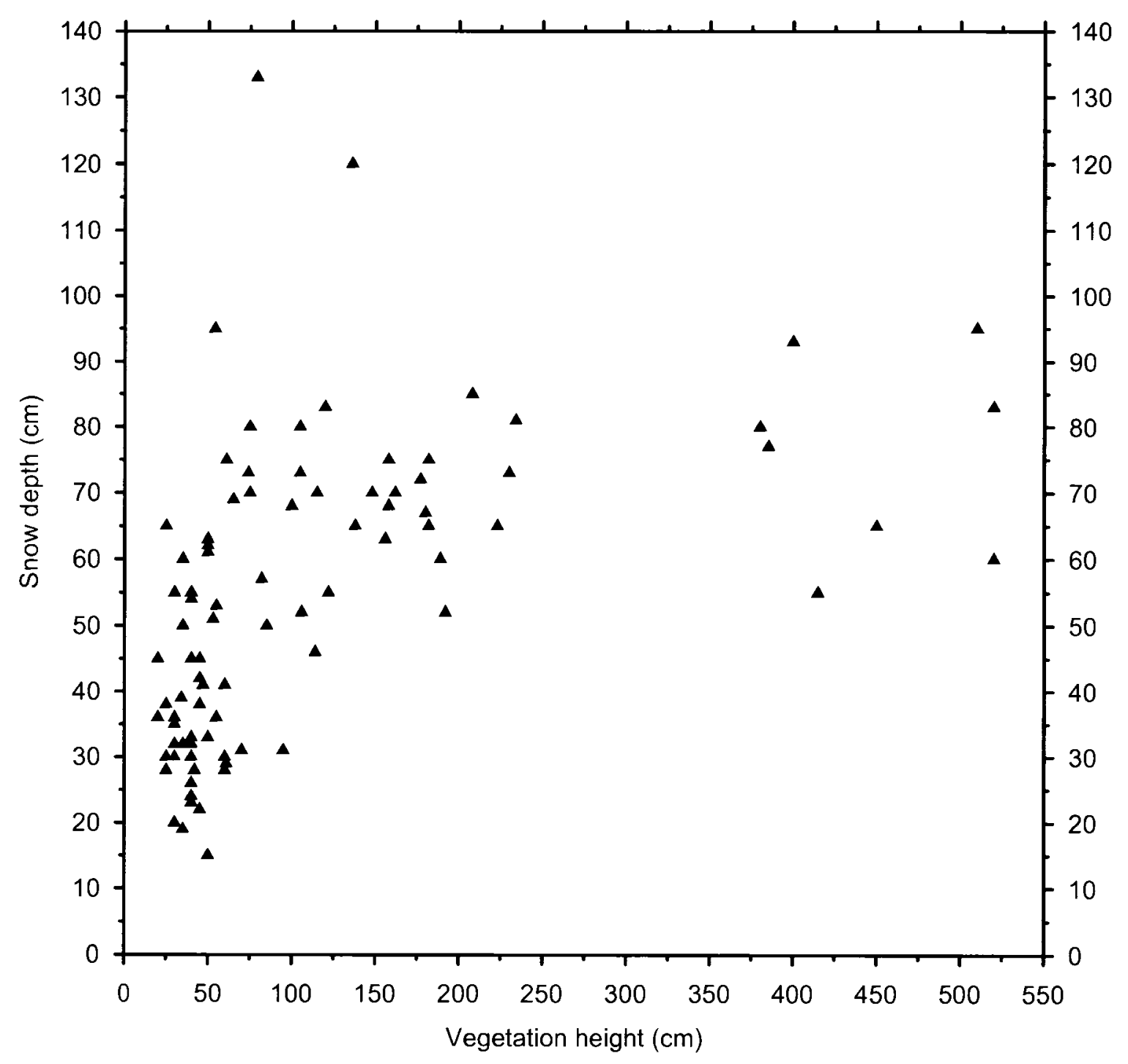

Figure 4.7 Snow depth $(\mathrm{cm})$ and vegetation height $(\mathrm{cm})$ measured along the snow courses at all sites $(\mathrm{n}=90)$. 
representing the maximum annual supply of snow to the region. Outliers of deeper snow depths are likely the result of blowing snow accumulating in tall deciduous shrubs.

During the study period more snow fell at Inuvik than at Tuktoyaktuk (Figure 4.8), but the majority of the difference in snow depth occurs across the shrubline boundary, between T2, the tall deciduous shrub site, and T4, the shrub-tundra site (Table 4.5). Therefore the major differences in snow depth along the transect are unlikely due to the precipitation gradient alone.

A one-way analysis of variance (ANOVA) (Sokal and Rohlf, 1995) was used to investigate variation in snow depths among the six study sites along the treeline transect. Tamhane's T2 procedure determined differences in mean snow depth between the sites at the $95 \%$ confidence level (Table 4.6 ). From this statistical procedure the study sites may be divided into two groups based on differences in snow depth. The first group includes sites T1 through T3. No statistically significant difference existed in mean snow depth between these three sites, and mean snow depths at these sites were significantly different from sites T4 to T6 (Table 4.6). The second group includes sites T4 through T6, where mean snow depths were significantly less than at sites south of T3. No significant difference existed in mean snow depths between $\mathrm{T} 4$ and $\mathrm{T} 5$, nor between $\mathrm{T} 5$ and $\mathrm{T} 6$ (Table 4.6).

The distribution of snow cover at the sites reflects two sources: i) the atmospheric supply of snow; and ii) snow that is redistributed by wind from local and regional sources (Pomeroy and Gray, 1995; Essery et al., 1999). Snow depths at T1 and T2 were deeper and less variable than at sites T4 through T6 (Figure 4.6). The tall forest canopy of T1 


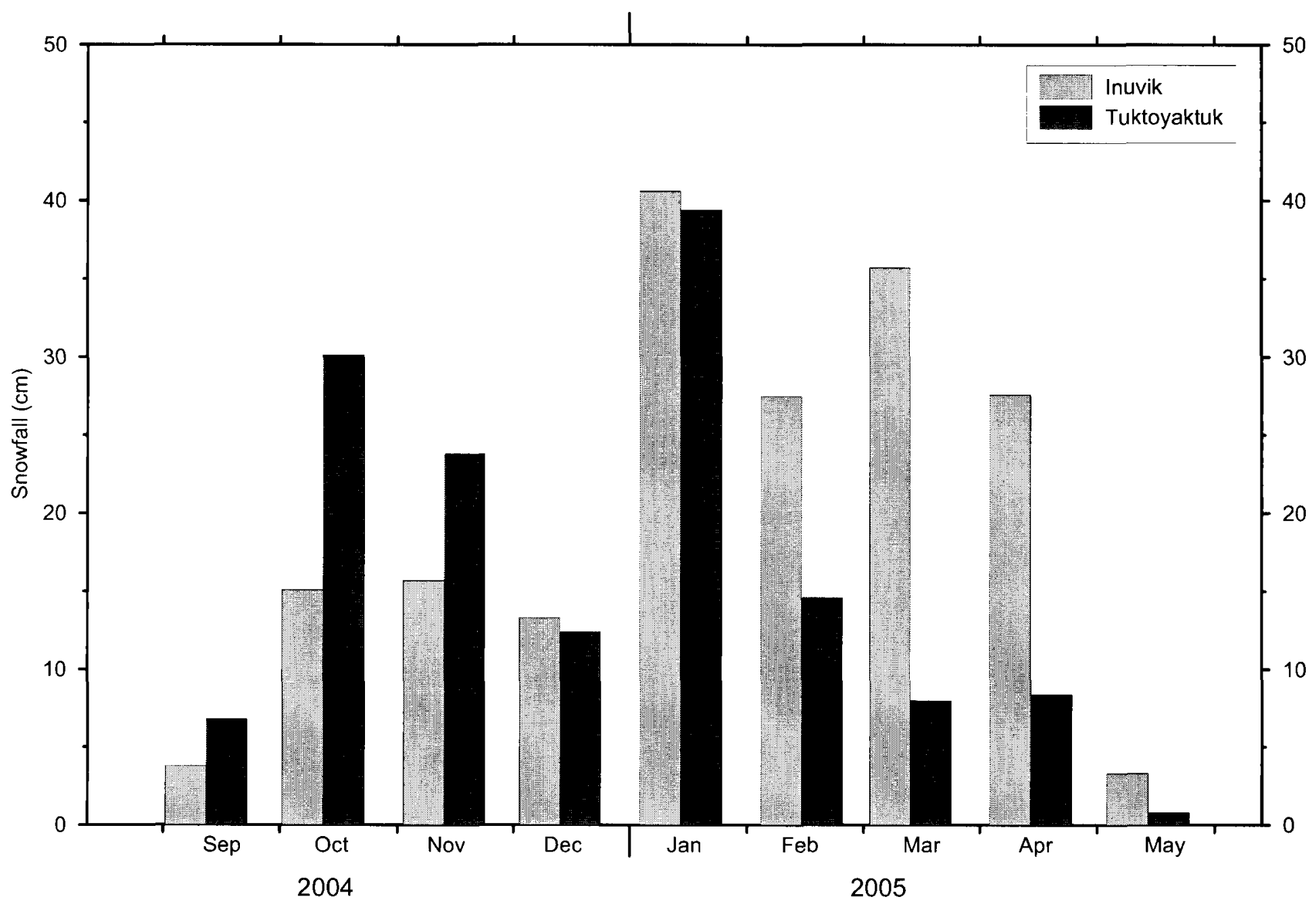

Figure 4.8 Monthly total snow fall (cm) at Inuvik and Tuktoyaktuk, September 2004 - May 2005. Total annual snow fall during the study period at Inuvik and Tuktoyaktuk was $183 \mathrm{~cm}$ and $144 \mathrm{~cm}$, respectively (Environment Canada, 2005). 
Table 4.5 Mean end of winter snow depths along the treeline transect and the difference in mean snow depth that occurs between adjacent sites.

\begin{tabular}{cccc}
\hline Site & $\begin{array}{c}\text { Distance from } \\
\text { Inuvik }(\mathbf{k m})\end{array}$ & $\begin{array}{c}\text { Mean snow } \\
\text { depth }(\mathbf{c m})\end{array}$ & $\begin{array}{c}\text { Difference in mean snow depth } \\
\text { between adjacent sites }(\mathbf{c m})\end{array}$ \\
\hline & & & \\
T1 & 0.00 & 78 & - \\
T2 & 17.10 & 75 & 11 \\
T3 & 19.60 & 64 & 19 \\
T4 & 27.80 & 45 & 8 \\
T5 & 66.80 & 37 & 6 \\
T6 & 86.50 & 31 & \\
\hline
\end{tabular}


Table 4.6 Results of the Tamhane T2 post-hoc test for the one-way analysis of variance for snow depth between all six study sites along the treeline transect $(n=30)$. P-values < 0.05 , indicating significant difference in mean snow depth between sites, are indicated in bold.

\begin{tabular}{ccccccc}
\hline & $\mathrm{T} 1$ & $\mathrm{~T} 2$ & $\mathrm{~T} 3$ & $\mathrm{~T} 4$ & $\mathrm{~T} 5$ & $\mathrm{~T} 6$ \\
\hline T1 & $\mathrm{X}$ & & & & & \\
T2 & 1.000 & $\mathrm{X}$ & & & & \\
T3 & 0.193 & 0.472 & $\mathrm{X}$ & & & \\
T4 & $<\mathbf{0 . 0 0 1}$ & $<0.001$ & $\mathbf{0 . 0 4 2}$ & $\mathrm{X}$ & & \\
T5 & $<\mathbf{0 . 0 0 1}$ & $<\mathbf{0 . 0 0 1}$ & $<\mathbf{0 . 0 0 1}$ & 0.354 & $\mathrm{X}$ & \\
T6 & $<\mathbf{0 . 0 0 1}$ & $<\mathbf{0 . 0 0 1}$ & $<\mathbf{0 . 0 0 1}$ & $\mathbf{0 . 0 0 1}$ & 0.519 & $\mathrm{X}$ \\
\hline
\end{tabular}


and the tall, dense shrub cover at T2 likely reduce near-ground wind speeds and limit redistribution of snow at either of the sites. As a result, the depth of snow at the sites reflects the atmospheric supply of snow to the area (Essery and Pomeroy, 2004). Snow depths at sites T3 through T6 were much more heterogeneous than at sites south of shrubline (Figure 4.6) because they were strongly affected by the redistribution of the snow cover by wind, in addition to the atmospheric supply. This is reflected by the larger coefficients of variation presented in Figure 4.6. More snow may fall at T3 than T6, but the distribution of snow at sites north of shrubline is predominately controlled by the snow-retention capacity of shrubs at the sites (Sturm et al., 2001a). Once snow depths have exceeded this threshold and the shrubs are filled with snow, the sites behave as aerodynamically open fields (Pomeroy and Gray, 1995) and the supplementary mobile snow is available to be transported to local or regional sinks, including larger shrubs that have not reached their snow-retention threshold or to topographic depressions.

Snow depths were most variable at T3, where the distribution of the snow cover was heavily affected by wind redistribution (Figure 4.6). Interestingly, mean snow depth at $\mathrm{T} 3$ was not significantly different from mean snow depths at sites $\mathrm{T} 1$ and $\mathrm{T} 2$, two sites predominately controlled by the atmospheric supply of snow with little wind redistribution of the snow cover (Figure 4.9; Table 4.6). The lack of a significant difference in mean snow depths between T3 and sites south of the shrubline was due to the presence and abundance of large alder shrubs at T3, which have a high snowretention capacity. The wide spacing of large alder shrubs at T3 allowed wind gusts to erode snow from the clearings between the large shrubs (Pomeroy and Gray, 1995) and transported it to large shrubs throughout the site. Although there was significant 


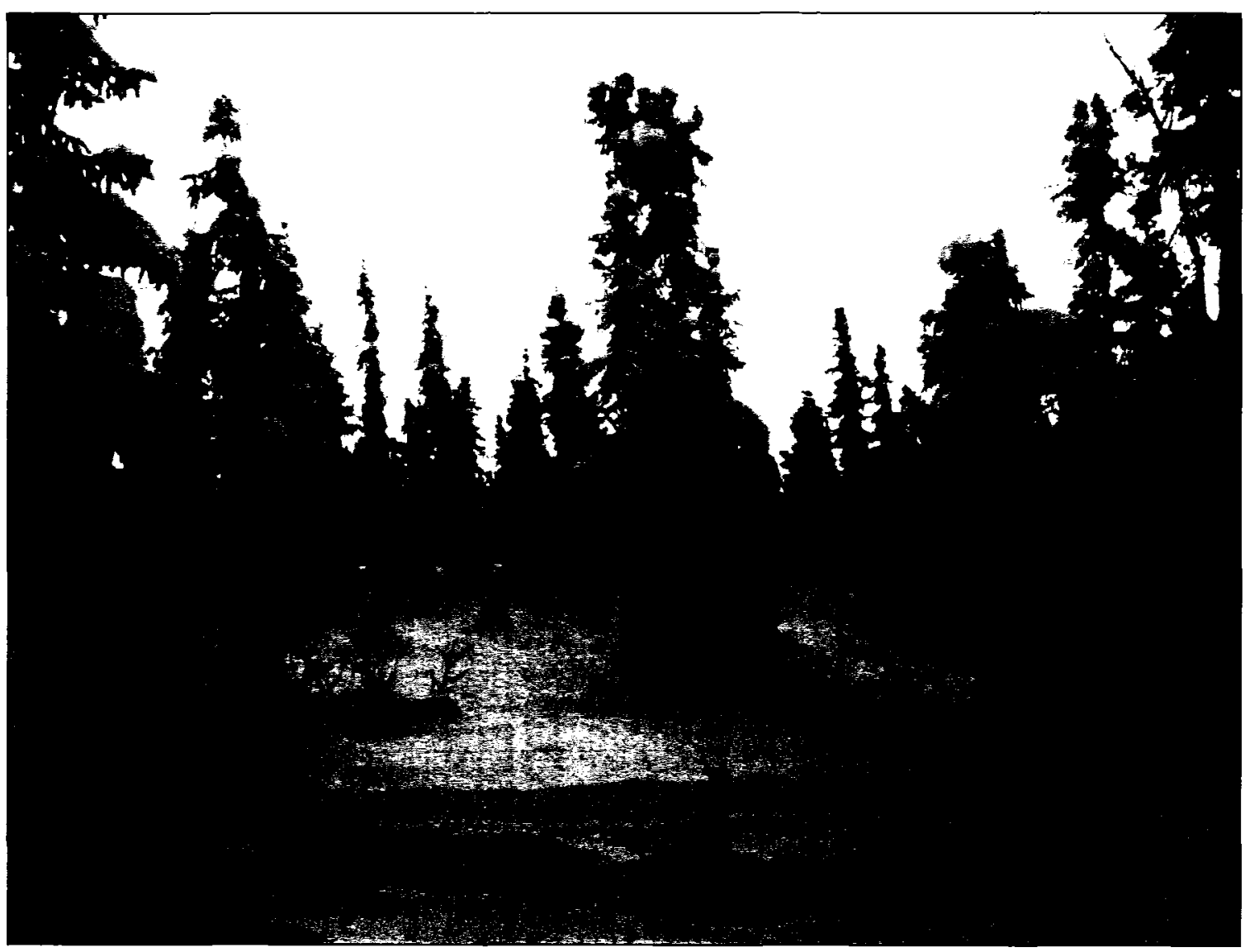

Figure 4.9 Snow cover at T1, November 2005. The snow course along which snow depths were recorded is visible in the foreground of the photograph. 
redistribution of snow at $\mathrm{T} 3$, the presence and abundance of large alders means that much of the snow being transported around the site was retained by local large shrubs and there was relatively little net loss of snow from the site. The accumulation of blowing snow in the branch matrices of large alder shrubs and on the lee side of the shrubs often results in large snow drifts occurring where shrubs are present (Figure 4.10) (Sturm et al., 2001b).

The decreased abundance of large alders north of $\mathrm{T} 4$ reduced the snow retention capacity of those sites, and therefore mean snow depths were significantly lower than at T3. Winter storm winds in the region are predominately from the northwest (Environment Canada, 2004), therefore sites with large, abundant shrubs such as T2 and T3 may be the destination for blowing snow from tundra areas northwest of T3. The effect of wind redistribution at the sites is evident in Figure 4.6, which shows that minimum snow depths were similar at sites north of the shrubline, where snow was transported from the clearings between shrubs, but maximum snow depths depended on the height of the largest shrubs, and decreased at tundra sites north of T3. Maximum snow depths were highest close to the shrubline boundary at T2 and T3, because these sites are the destination for regional blowing snow during northerly winds. Maximum snow depth was greater at T3 than T2 because regional blowing snow transported from north of T3 was only available to T2, once the snow retention threshold of the vegetation at T3 had been exceeded.

\subsubsection{Snow data - snow courses vs. logger installations}

Snow depths were measured along the two perpendicular snow courses $(n=30)$, and within a 3-m radius of the ground temperature logger installation $(n=5)$ (Figure 4.11). Snow depths were measured at both of these locations to determine if snow depths 


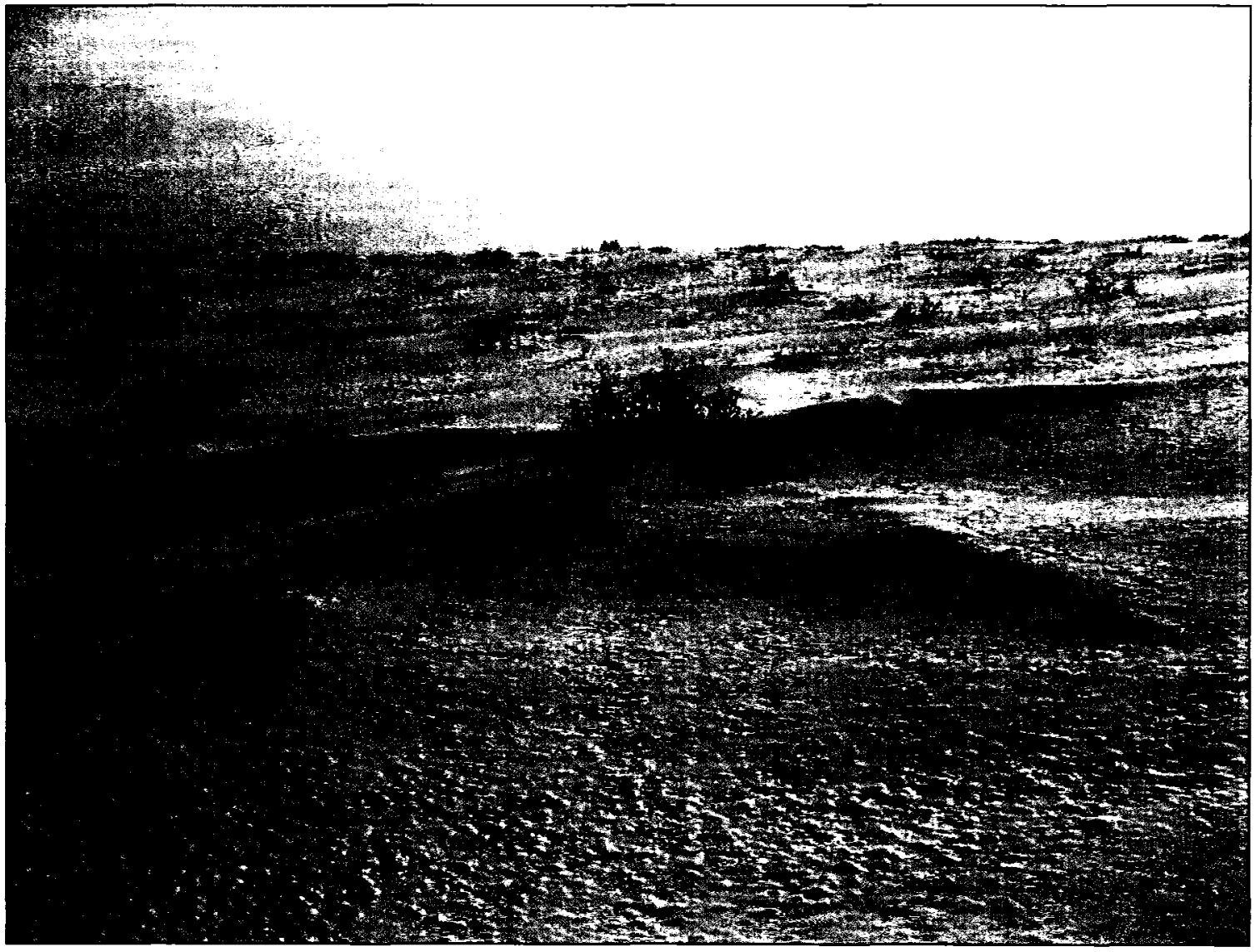

Figure 4.10 Patterns of snow drifting around a shrub, March 2005. Note the star-shaped formation of the drift. The deep axes of snow surrounding the shrub may represent dominant wind directions. 


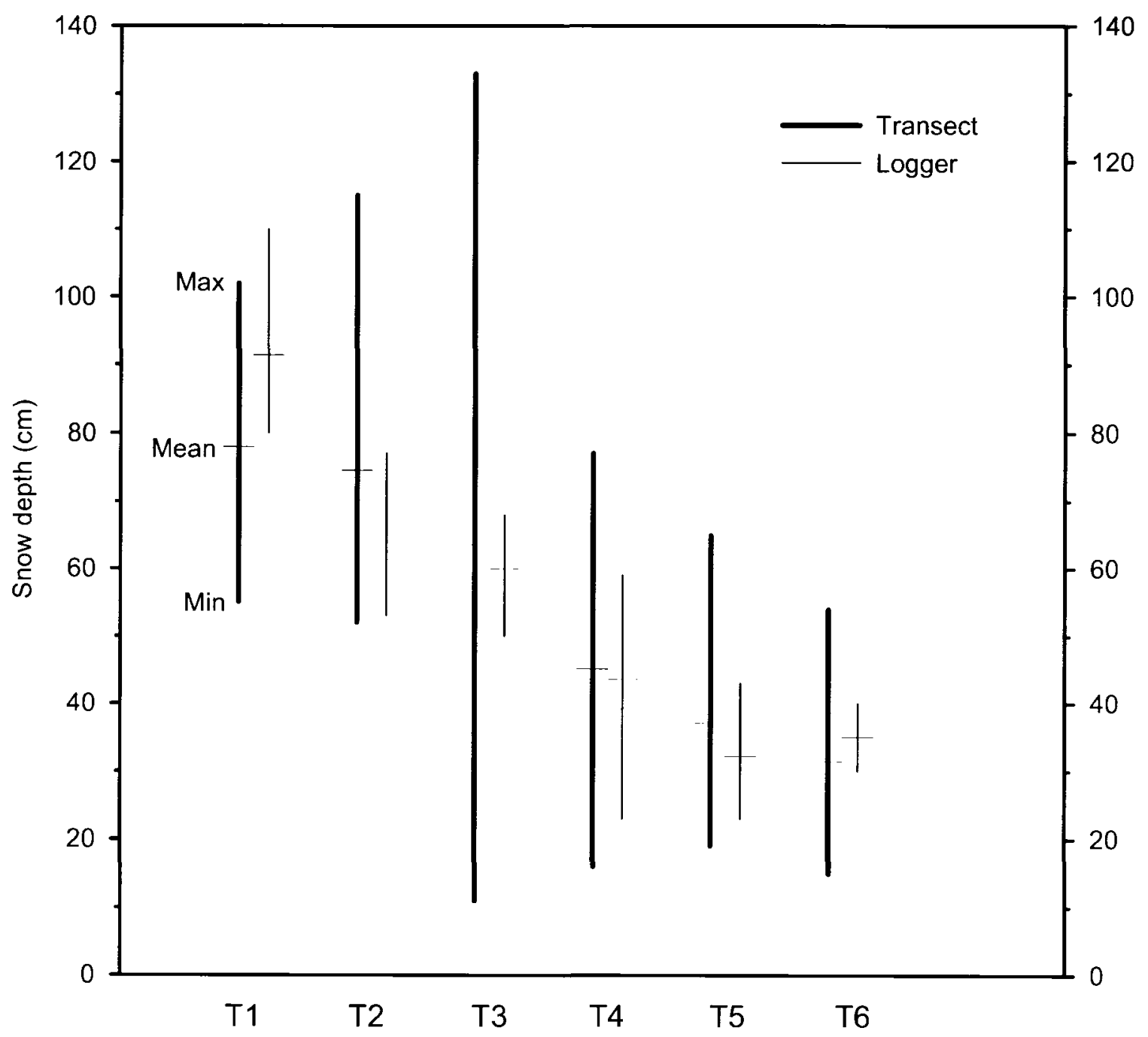

Figure 4.11 Snow depths along the snow courses $(n=30)$ and within a 3 -m radius of the ground temperature loggers $(n=5)$ at each site, March 2005. The horizontal lines represent the mean snow depth at each location. Vertical lines represent the maximum and minimum extent of snow depths at the sites. 
within a 3-m radius of the ground temperature installations, the area of snow which would affect ground temperatures to the $100-\mathrm{cm}$ depth, are representative of snow depths at the site, and vice versa. The range in snow depths was greater along the transects, than surrounding the loggers, primarily because more measurements were taken along the transects.

Snow depths along the transects were compared to snow depths within a $3-\mathrm{m}$ radius of the ground temperature installation using either a t-test, if the snow depths were normally distributed at both locations, or a Mann-Whitney U test if the snow depths did not fit the assumptions for parametric testing. The median snow depths were significantly different only at $\mathrm{T} 1(\mathrm{Z}=-2.10, \mathrm{P}=0.0350)$ (Table 4.7). Transect snow depths were therefore representative of snow depth conditions surrounding the ground temperature installations at sites $\mathrm{T} 2, \mathrm{~T} 3, \mathrm{~T} 4, \mathrm{~T} 5$, and $\mathrm{T} 6$. The difference between mean snow depths at T1 may not have a physically significant effect on ground temperatures at the site because snow depths exceeded $70 \mathrm{~cm}$ at both locations, and ground temperatures will vary minimally beneath snow depths of this magnitude (Figure 2.4) (Williams and Smith, 1989).

\subsubsection{Snow density across treeline}

Snow densities measured at the sites are presented in Figure 4.12. Mean snow density varied little among the sites, between 0.15 and $0.24 \mathrm{~g} / \mathrm{cm}^{3}$. Mean and maximum snow densities were greatest at T2. Mean and minimum snow densities were lowest at T4. Snow densities at the northern end of the transect were much lower than the values 
Table 4.7 Results from the statistical tests between snow depths along the snow courses $(n=30)$, and snow depths within a 3-m radius of the ground temperature logger at each site $(n=5)$. P-values $<0.05$ are in bold and indicate significant difference between means (Student's $t$ ) and medians (Mann-Whitney) of the groups.

\begin{tabular}{|c|c|c|c|c|c|}
\hline & t-stat & Z-stat & $\begin{array}{c}\begin{array}{c}\text { Mann- } \\
\text { Whitney } \\
\text { U }\end{array} \\
\end{array}$ & $\begin{array}{c}\text { degrees } \\
\text { of } \\
\text { freedom }\end{array}$ & p-value \\
\hline $\mathrm{T1}$ & & -2.10 & 30.50 & & 0.0350 \\
\hline T2 & 1.92 & & & 31 & 0.0640 \\
\hline T3 & 0.59 & & & 27 & 0.5600 \\
\hline T4 & 0.25 & & & 35 & 0.8030 \\
\hline T5 & 0.82 & & & 33 & 0.4210 \\
\hline T6 & & -1.32 & 35.50 & & 0.1890 \\
\hline
\end{tabular}




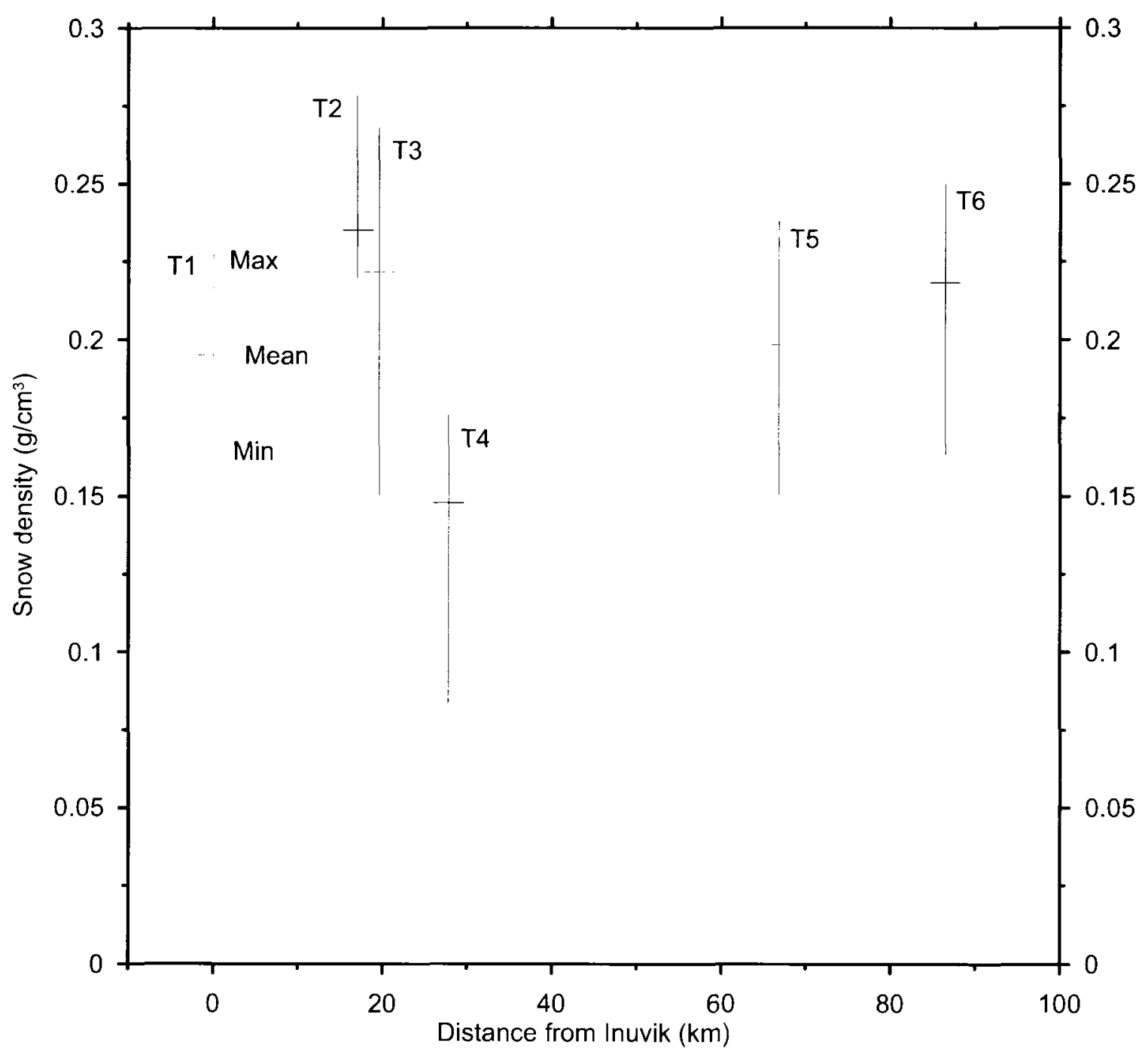

Figure 4.12 Snow density $\left(\mathrm{g} / \mathrm{cm}^{3}\right)$ at all study sites across the treeline transition, end of March $2005(n=8)$. Vertical lines represent the maximum and minimum extent of snow density at each of the sites. Horizontal lines represent the mean snow density at each site. 
between 0.35 and $0.40 \mathrm{~g} / \mathrm{cm}^{3}$ reported by Mackay and MacKay (1974) at Garry Island. The lower snow densities recorded in this study may be due to the location of sampling. Many of the density measurements recorded by Mackay and MacKay (1974) are from snow drifts on the lee side of slopes or in topographic depressions, whereas in this study all densities were measured on hill tops. There are also fewer shrubs at Garry Island, allowing for the snow pack to become more densely packed.

The lack of a trend in snow density across treeline may also be the result of the proportion of depth-hoar in the snow pack later in winter. A depth-hoar layer was observed at all sites, and was generally mixed with the lowest-lying vegetation at the site. The density of the depth hoar layer ranged between 0.15 and $0.27 \mathrm{~g} / \mathrm{cm}^{3}$. Density measurements of the depth hoar are error prone because depth hoar is extremely fragile, making it difficult to extract a well-defined volume from the snow profile. The proportion of depth hoar in the snow profile is perhaps a more reliable measure of the insulation property of the snow pack (Sturm and Benson, 1997). At sites T4 to T6 the snow cover was thin, and the depth-hoar layer represented a larger percentage of the entire snow pack (40-50\%), compared to $25-35 \%$ of the snow pack at sites T1 to T3. An increase in the proportion of depth hoar in the snow pack reduces the overall bulk density of the entire snow profile.

The thermal insulation quality of the snow pack is expressed as the thermal resistance $\left(R_{s}\right)$ of the snow pack, and is controlled by the thermal conductivity $\left(\lambda_{s}\right)$ and the thickness of the snow layer $\left(\Delta \mathrm{H}_{\mathrm{s}}\right)$ : 


$$
\text { (4.3) } R_{s}=\frac{\Delta H}{\lambda_{s}}
$$

(Lunardini, 1981)

Where the thermal conductivity of snow (for density, $\rho<0.60$ ) can be estimated using:

$$
\text { (4.4) } \lambda_{s}=10^{(2.650 \rho-1.652)}
$$

Table 4.8 presents estimates for the thermal conductivity and thermal resistance of the snow pack at sites T1 to T6. Thermal resistance of the snow pack was largest at sites T1 to $\mathrm{T} 4\left(10.6\right.$ to $\left.7.4 \mathrm{~m}^{2} \mathrm{~K} \mathrm{~W}^{-1}\right)$. North of $\mathrm{T} 4$, at the low shrub tundra sites, the thermal resistance of the snow pack was lower $\left(4.9\right.$ to $\left.3.7 \mathrm{~m}^{2} \mathrm{~K} \mathrm{~W}^{-1}\right)$. This suggests that $\left|\mathrm{Q}_{\mathrm{G}}\right|$ is greatest at the low shrub tundra sites during winter.

\subsection{Subsurface conditions}

\subsubsection{Organic-layer thickness}

Mean organic-layer thicknesses from each of the sites are presented in Figure 4.13. The organic-layer was thickest at $\mathrm{T} 3(39 \mathrm{~cm})$, and thinnest at $\mathrm{T} 2(8 \mathrm{~cm})$. The organic-layer at T2 was likely thin because it had not fully redeveloped since the 1968 fire. Mean organic-layer thicknesses varied little between T1 $(19 \mathrm{~cm}), \mathrm{T} 4(14 \mathrm{~cm}), \mathrm{T} 5$ $(18 \mathrm{~cm})$, and T6 $(16 \mathrm{~cm})$. Differences in organic-layer thickness at the sites influence the ground thermal regime through differences in surface moisture content and bulk density (Burn, 2004; Karunaratne and Burn, 2004). 
Table 4.8 Thermal properties of the snow pack at sites T1 to T6.

\begin{tabular}{ccccc}
\hline & $\begin{array}{c}\text { Mean snow } \\
\text { density }\left(\mathrm{g} \mathrm{cm}^{-3}\right)\end{array}$ & $\begin{array}{c}\text { Thermal } \\
\text { conductivity } \\
\left(\mathrm{W} \mathrm{m}^{-1} \mathrm{~K}^{-1}\right)\end{array}$ & $\begin{array}{c}\text { Mean snow } \\
\text { depth }(\mathrm{m})\end{array}$ & $\begin{array}{c}\text { Thermal } \\
\text { resistance } \\
\left(\mathrm{m}^{2} \mathrm{~K} \mathrm{~W}^{-1}\right)\end{array}$ \\
\hline T1 & 0.20 & 0.073 & 0.78 & 10.6 \\
T2 & 0.24 & 0.094 & 0.75 & 8.1 \\
T3 & 0.22 & 0.086 & 0.64 & 7.4 \\
T4 & 0.15 & 0.055 & 0.45 & 8.2 \\
T5 & 0.20 & 0.075 & 0.37 & 4.9 \\
T6 & 0.22 & 0.084 & 0.31 & 3.7 \\
\hline
\end{tabular}

${ }^{a}$ estimated from Sturm et al. (1997) 


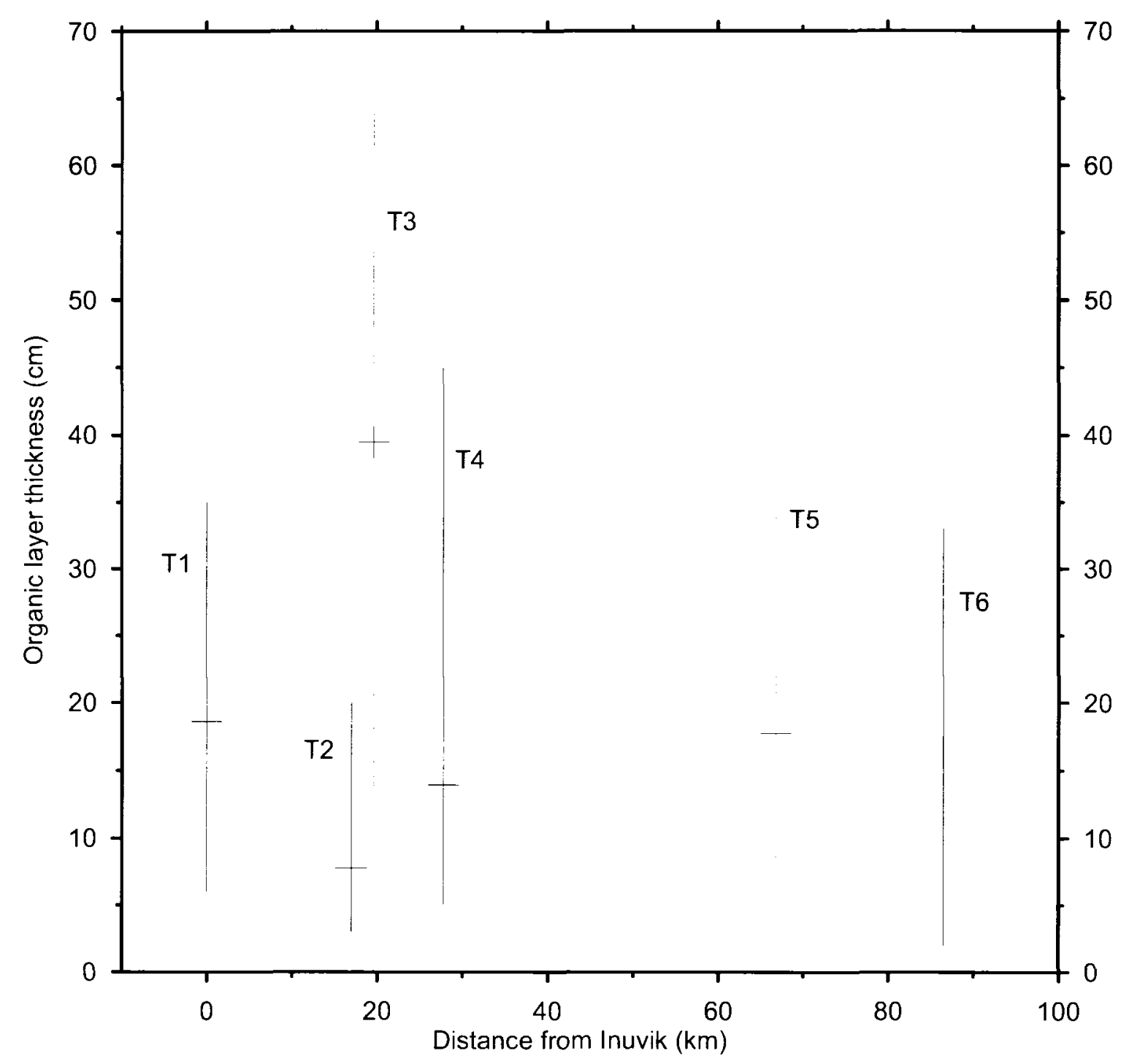

Figure 4.13 Organic-layer thicknesses $(\mathrm{cm})$ along the snow course at $T 1$ to $T 6(n=15)$. The vertical lines are drawn between the maximum and minimum organic-layer thickness values recorded in August, 2005. The ticks indicate the mean values for organic-layer thickness. 


\subsubsection{Surface soil moisture}

The gravimetric and volumetric surface $(0-10 \mathrm{~cm})$ soil moisture contents for each of the sites are presented in Table 4.9. Because of the variability in bulk density of the surface soil, due to differences in organic content, the volumetric soil moisture content is a better indicator of surface wetness than the gravimetric soil moisture content. Surface volumetric soil moisture content was highest at T3 $\left(0.54 \mathrm{~cm}^{3} \mathrm{~cm}^{-3}\right)$ and lowest at T4 $(0.28$ $\mathrm{cm}^{3} \mathrm{~cm}^{-3}$ ). Volumetric moisture content was similar at the other sites (approximately $\left.0.40 \mathrm{~cm}^{3} \mathrm{~cm}^{-3}\right)$.

\subsection{Soil properties}

Soil properties of the active layer influence the near-surface ground thermal regime through the thermal conductivity. If the thermal conductivity of the active layer is similar between sites, differences in the near-surface ground thermal regime must be the result of differences in air temperatures and/or surface conditions. Soil properties of the active layer at each of the sites are presented in Table 4.9.

The thermal conductivity of the active layer was estimated using the dry bulk density, particle density, and volumetric moisture content of mineral soils sampled throughout the active layer. The estimation of active layer properties excluded the top 10 $\mathrm{cm}$ of the soil profile, as this was predominately organic material. A sample volume of 1 $\mathrm{cm}^{3}$ with no organic content and a particle density of $2.65 \mathrm{~g} \mathrm{~cm}^{-3}$ (Brady and Weil, 2002) were assumed for all soils. To estimate the thermal conductivity of the soils, the porosity of the soils must first be calculated, which requires the volume of the soil particles $\left(V_{s}\right)$, the volume of the voids $\left(\mathrm{V}_{\mathrm{v}}\right)$, and the volume of organics in the soil $\left(\mathrm{V}_{\mathrm{o}}\right)$ : 
Table 4.9 Soil properties at sites T1 to T6. Mean active layer soil properties were calculated excluding surface samples $(0-10 \mathrm{~cm})$, as surface samples were predominately organic material. All soil samples were collected between August 13 and 27, 2005.

\begin{tabular}{|c|c|c|c|c|c|c|}
\hline $\begin{array}{l}\text { Site and } \\
\text { date } \\
\text { sampled }\end{array}$ & $\begin{array}{l}\text { Depth } \\
(\mathrm{cm})\end{array}$ & $\begin{array}{c}\text { Soil } \\
\text { description }\end{array}$ & $\begin{array}{c}\mathrm{BD}^{\mathrm{a}} \\
\left(\mathrm{g} \mathrm{cm}^{-3}\right)\end{array}$ & $\begin{array}{c}V_{M M C^{b}} \\
\left(\mathrm{~cm}^{3} \mathrm{~cm}^{-3}\right)\end{array}$ & $\begin{array}{c}G M C^{c} \\
(\%)\end{array}$ & $\begin{array}{c}\mathrm{LOI}^{\mathrm{d}} \\
(\%)\end{array}$ \\
\hline & $0-10$ & & 1.32 & 0.37 & 28 & 4.80 \\
\hline & $10-20$ & Clay loam & 1.59 & 0.39 & 25 & 4.00 \\
\hline & $20-30$ & & 1.77 & 0.42 & 24 & 4.00 \\
\hline T1 & $30-40$ & & 1.63 & 0.41 & 25 & 4.00 \\
\hline \multirow[t]{3}{*}{ August 27} & $40-50$ & & 1.74 & 0.43 & 24 & 3.90 \\
\hline & $50-60$ & Clay loam & 1.76 & 0.38 & 22 & 3.70 \\
\hline & $60-70$ & Clay & 1.82 & 0.43 & 24 & 3.50 \\
\hline \multirow[t]{3}{*}{ Mean } & & Clay loam & 1.72 & 0.41 & 24 & 3.85 \\
\hline & $10-20$ & Clay loam & 1.31 & 0.40 & 30 & 5.80 \\
\hline & $20-30$ & & 1.44 & 0.34 & 24 & 4.20 \\
\hline $\mathrm{T} 2$ & $30-40$ & & 1.51 & 0.35 & 23 & 5.10 \\
\hline \multirow[t]{3}{*}{ August 18} & $40-50$ & & 1.42 & 0.44 & 31 & 7.20 \\
\hline & $50-60$ & Sandy clay & 0.75 & 0.59 & 80 & 23.10 \\
\hline & $60-70$ & Clay & 1.65 & 0.41 & 25 & 3.70 \\
\hline \multirow[t]{3}{*}{ Mean } & & Clay loam & 1.39 & 0.42 & 35 & 8.18 \\
\hline & $0-10$ & & 0.60 & 0.54 & 89 & 15.40 \\
\hline & $10-20$ & Silty clay & 1.28 & 0.36 & 29 & 4.70 \\
\hline T3 & $20-30$ & & 1.67 & 0.47 & 28 & 4.30 \\
\hline \multirow[t]{3}{*}{ August 15} & $30-40$ & & 1.51 & 0.47 & 31 & 4.60 \\
\hline & $40-50$ & Silty clay & 1.55 & 0.42 & 27 & 4.20 \\
\hline & $50-60$ & Silty clay & 1.64 & 0.43 & 26 & 4.30 \\
\hline \multirow[t]{3}{*}{ Mean } & & Silty clay & 1.53 & 0.43 & 28 & 4.42 \\
\hline & $0-10$ & & 0.86 & 0.28 & 32 & 9.50 \\
\hline & $10-20$ & Silty clay & 1.22 & 0.32 & 26 & 4.40 \\
\hline T4 & $20-30$ & & 1.20 & 0.40 & 33 & 5.40 \\
\hline \multirow[t]{3}{*}{ August 13} & $30-40$ & & 1.58 & 0.38 & 24 & 4.20 \\
\hline & $40-50$ & Clay & 1.60 & 0.39 & 25 & 4.10 \\
\hline & $50-60$ & Silty clay & 1.64 & 0.40 & 24 & 3.80 \\
\hline \multirow[t]{3}{*}{ Mean } & & Silty clay & 1.45 & 0.38 & 26 & 4.38 \\
\hline & $0-10$ & & 0.54 & 0.42 & 79 & 27.70 \\
\hline & $10-20$ & Clay loam & 1.35 & 0.25 & 19 & 2.90 \\
\hline T5 & $20-30$ & & 1.51 & 0.34 & 23 & 3.30 \\
\hline \multirow{2}{*}{ August 24} & $30-40$ & Clay loam & 1.50 & 0.35 & 23 & 3.20 \\
\hline & $40-50$ & Clay loam & 1.73 & 0.36 & 21 & 3.50 \\
\hline \multirow[t]{2}{*}{ Mean } & & Clay loam & 1.52 & 0.33 & 21 & 3.23 \\
\hline & $0-10$ & & 0.61 & 0.45 & 74 & 27.00 \\
\hline T6 & $10-20$ & Clay loam & 1.05 & 0.37 & 35 & 8.90 \\
\hline \multirow{2}{*}{ August 22} & $20-30$ & Clay loam & 1.09 & 0.35 & 32 & 7.80 \\
\hline & $30-40$ & Clay loam & 1.37 & 0.41 & 30 & 9.00 \\
\hline Mean & & Clay loam & 1.17 & 0.37 & 32 & 8.57 \\
\hline
\end{tabular}


(4.5) $\quad V_{s}=\frac{M_{s}}{\rho_{s}}$

(4.6) $V_{v}=V_{t}-V_{s}-V_{o}$

Where $M_{s}$ is the mass of the soil particles $(\mathrm{g}), \rho_{\mathrm{s}}$ is the particle density $\left(\mathrm{g} \mathrm{cm}^{-3}\right)$, and $V_{t}$ is the total volume of the soil $\left(\mathrm{cm}^{3}\right)$. The porosity of the soil (E) and the percent saturation $(\%)$ may then be estimated:

$$
\text { (4.7) } E=\frac{V_{v}}{V_{t}} \times 100 \%
$$

(4.8) Percent saturation $=\frac{V w}{V S} \times 100 \%$

Table 4.10 presents estimated porosity and percent saturation values for active layer soils at each of the sites. The porosity is likely underestimated at T1, as Table 4.10 shows that the volume of water (VMC) exceeds the porosity of the soil, resulting in a supersaturated soil, which is impossible, as the active layer was thawed during sampling. The underestimation of the porosity at $\mathrm{T} 1$ is likely a result of an underestimation of the particle density at the site. An increase in the particle density results in an increase in porosity.

The assumption of no organic material in the soils may also lead to significant error in the porosity of the soil. This assumption is reasonable for most sites, however at T6 this assumption may lead to potential error in the volume of the voids, due to the relatively high organic content of the soil at T6 compared to the other sites (Table 4.9).

Once the porosity of the soil has been estimated, it is then possible to estimate the thermal conductivity of the soil by determining the thermal conductivity of the soil constituents: 
Table 4.10 Thermal conductivity of the active layer soils at sites T1 to T6. Bulk density and volumetric moisture content are the calculated mean values from the soil profiles excluding surface organics at each site. Porosity and percent saturation for each site are based on these mean values.

\begin{tabular}{|c|c|c|c|c|c|c|}
\hline & $\begin{array}{l}\text { Bulk density } \\
\left(\mathrm{g} \mathrm{cm}^{-3}\right)\end{array}$ & $\begin{array}{c}V M C^{a} \\
\left(\mathrm{~cm}^{3} \mathrm{~cm}^{-3}\right)\end{array}$ & $\begin{array}{l}\text { Particle } \\
\text { density }^{b} \\
\left(\mathrm{~g} \mathrm{~cm}^{-3}\right)\end{array}$ & $\begin{array}{c}\text { Porosity } \\
(\%)\end{array}$ & $\begin{array}{c}\text { Percent } \\
\text { saturation (\%) }\end{array}$ & $\begin{array}{c}\text { Thermal } \\
\text { conductivity } \\
\left(\mathbf{W m}^{-1} \mathbf{K}^{-1}\right)\end{array}$ \\
\hline T1 & 1.72 & 0.41 & 2.65 & 35 & 117 & 1.63 \\
\hline T2 & 1.35 & 0.42 & 2.65 & 49 & 86 & 1.04 \\
\hline T3 & 1.53 & 0.43 & 2.65 & 43 & 99 & 1.45 \\
\hline T4 & 1.45 & 0.38 & 2.65 & 45 & 84 & 1.10 \\
\hline T5 & 1.52 & 0.33 & 2.65 & 43 & 77 & 1.07 \\
\hline T6 & 1.17 & 0.37 & 2.65 & 56 & 66 & 0.65 \\
\hline
\end{tabular}


(4.9) $\lambda_{\mathrm{s}}=\lambda_{\mathrm{m}}{ }^{1-\mathrm{E}} \times \lambda_{\mathrm{w}}{ }^{\mathrm{E}-\mathrm{q}-\mathrm{r}} \times \lambda_{\mathrm{a}}{ }^{\mathrm{q}} \times \lambda_{i}^{\mathrm{r}}$

(Williams and Smith, 1989)

Where $\lambda_{s}$ is the thermal conductivity of the soil, $\lambda_{m}$ is the thermal conductivity of the soil materials $\left(2.92 \mathrm{~W} \mathrm{~m}^{-1} \mathrm{~K}^{-1}\right)$ if the soil materials were assumed to be clay minerals, $\lambda_{w}$ is the thermal conductivity of water, $\lambda_{a}$ is the thermal conductivity of air, $\lambda_{i}$ is the thermal conductivity of ice, $\mathrm{E}$ is the porosity of the soil, $q$ is the volume fraction of air in the sample, and $r$ is the volume fraction of ice in the sample.

Estimated thermal conductivities for all of the active-layer soils using equations 4.5 through 4.9 are presented in Table 4.10. There was considerable variation in activelayer thermal conductivity between sites due to differences in bulk density, moisture content and porosity. Active-layer thermal conductivity was highest at $\mathrm{T} 1\left(1.63 \mathrm{~W} \mathrm{~m}^{-1}\right.$ $\left.\mathrm{K}^{-1}\right)$ and was approximately two and half times greater than at $\mathrm{T} 6\left(0.65 \mathrm{~W} \mathrm{~m}^{-1} \mathrm{~K}^{-1}\right)$, in association with a higher bulk density and volumetric moisture content. The low porosity and high percent saturation at $\mathrm{T} 1$ also increased the thermal conductivity of the active layer at $\mathrm{T} 1$, although the porosity may be underestimated due an underestimation of particle density. The thermal conductivity of the active layer was lowest at T6 due to the low bulk density, which is likely the result of the high organic content in the active layer (Table 4.9). Active-layer thermal conductivities were similar at T2, T4, and T5, therefore differences in ground temperature between these sites are not controlled by differences in active-layer properties.

\subsection{Thaw depth}

The depth of thaw is dependent on whether measurements were made in a hummock top or an interhummock trough. Hummock tops generally have a thin organic 
layer overlying mineral soil. The organic layer of interhummock troughs are typically thicker than that of hummock tops, as organics tend to accumulate in the moist trough areas. The low thermal conductivity of the trough organics inhibits the ground from warming during summer, and therefore the depth of thaw tends to be thinner than in hummock tops (Smith, 1975).

Thaw depths measured in hummock tops and interhummock troughs are presented in Figure 4.14. At all of the sites mean thaw depths were deeper in the hummock tops than in the interhummock troughs. Mean hummock-top thaw depths were greater at sites T1 to T4 (53 to $59 \mathrm{~cm}$ ), than at sites T5 and T6 (approximately $45 \mathrm{~cm}$ ). Mean interhummock thaw depth was greatest at T2 $(52 \mathrm{~cm})$, because the hummocks at T2 are not as developed as at other sites along the transect and the organic layer in the interhummock troughs has not fully redeveloped since the 1968 fire. Mean interhummock thaw depths at the remainder of the sites ranged between 29 and $39 \mathrm{~cm}$. 


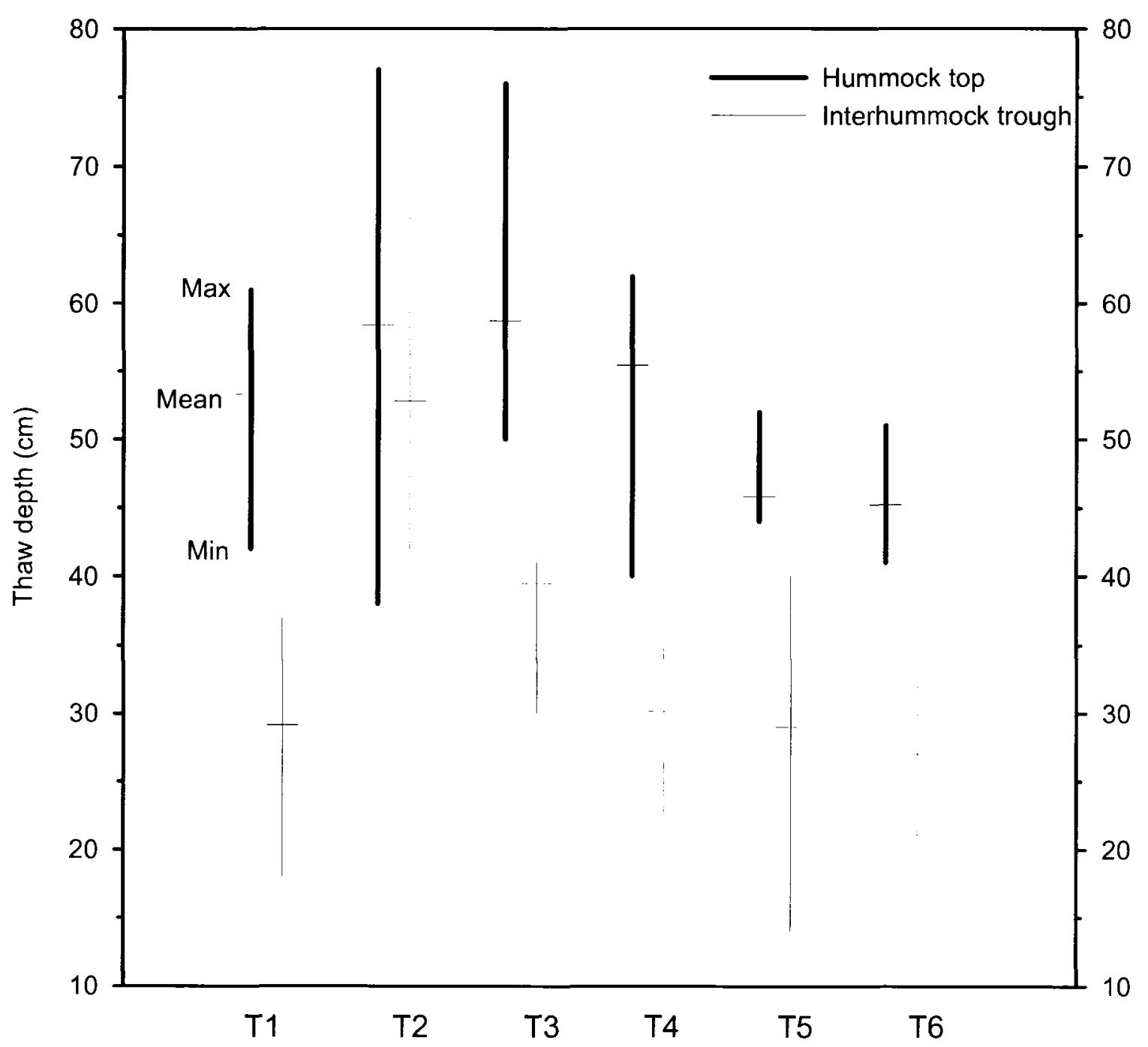

Figure 4.14 Thaw depths $(\mathrm{cm})$ in hummock tops and in interhummock troughs at sites T1 to T6, late August $2005(n=15)$. The vertical lines are drawn between the maximum and minimum thaw depth values recorded in August, 2005. The ticks indicate the mean values for thaw depth. 


\section{Chapter 5}

\section{Air and near-surface ground temperatures across treeline}

\subsection{Introduction}

In chapter 4 it was shown that surface and subsurface conditions at the study sites were variable across treeline. The differences in surface and subsurface conditions between sites may alter the partitioning of fluxes at the surface, and consequently air and near-surface ground temperatures at the study sites. This chapter investigates the effect of surface and subsurface conditions on air and near-surface ground temperatures along the treeline transect. Specifically, this chapter will: 1) describe the variation in air and near-surface ground temperatures; 2) investigate the relations between air and surface temperatures; 3 ) investigate the relations between surface temperatures, active-layer temperatures and temperatures at the top of permafrost; and 4) determine the physical characteristics that influence near-surface ground temperatures at the study sites.

Due to the error associated with the temperature instruments $\left(+/-0.5^{\circ} \mathrm{C}\right.$; see section 3.4.2) there is a maximum potential error of $+/-1.0^{\circ} \mathrm{C}$ in the calculation of the surface, thermal and total offsets. In reality, the error associated with the annual offset calculations is less than $+/-1.0^{\circ} \mathrm{C}$, because the sign of the error will be opposite in the freezing and thawing seasons. For example, if the air temperature instrument consistently records $0.5^{\circ} \mathrm{C}$ too high and the surface temperature instrument consistently records $0.5^{\circ} \mathrm{C}$ too low, then at any specific moment there is an error of $+1-1.0^{\circ} \mathrm{C}$ in the surface offset. However, at an annual scale the error associated with the surface offset will be less than 
$1.0^{\circ} \mathrm{C}$, because during the thawing season the sign of the error will be positive and during the freezing season the sign of the error will be negative.

\subsection{Air temperatures across treeline}

Air temperatures were measured at the study sites from September 1, 2004 to September 1, 2005 (Figure 5.1). Annual mean air temperatures decreased northward along the entire length of the transect from $-8.4^{\circ} \mathrm{C}$ at $\mathrm{T} 1$, to $-10.8^{\circ} \mathrm{C}$ at $\mathrm{T} 6$, but there was little difference in annual mean air temperature north of T4 (Table 5.1).

\subsubsection{Freezing-season air temperatures}

Air temperatures dropped below $0^{\circ} \mathrm{C}$ at all sites on September 13. Air temperatures dropped rapidly at all sites during fall, and were similar along the transect (Figure 5.1). Air temperatures remained similar along the transect until mid February when air temperatures in the boreal forest site began to warm more quickly than air temperatures at the tundra sites (Figure 5.1).

Beginning in mid February a gradient in air temperatures developed across treeline. The magnitude of the air temperature gradient $\left({ }^{\circ} \mathrm{C} / \mathrm{km}\right)$ increased from March to June and was steepest between the boreal woodland site (T1) and the tall shrub site (T2), $17 \mathrm{~km}$ apart (Figure 5.2). The air temperature gradient was 2 to 4 times steeper between $\mathrm{T} 1$ and $\mathrm{T} 2$ than over the remaining $70 \mathrm{~km}$ between the tall shrub zone (T2) and the low shrub tundra (T6) (Figure 5.2).

The northward decrease in spring air temperatures prior to the open-water season and the fact that most of the change in spring air temperatures occurred between the boreal site and the shrub sites suggests that there are other factors, in addition to a coastal 


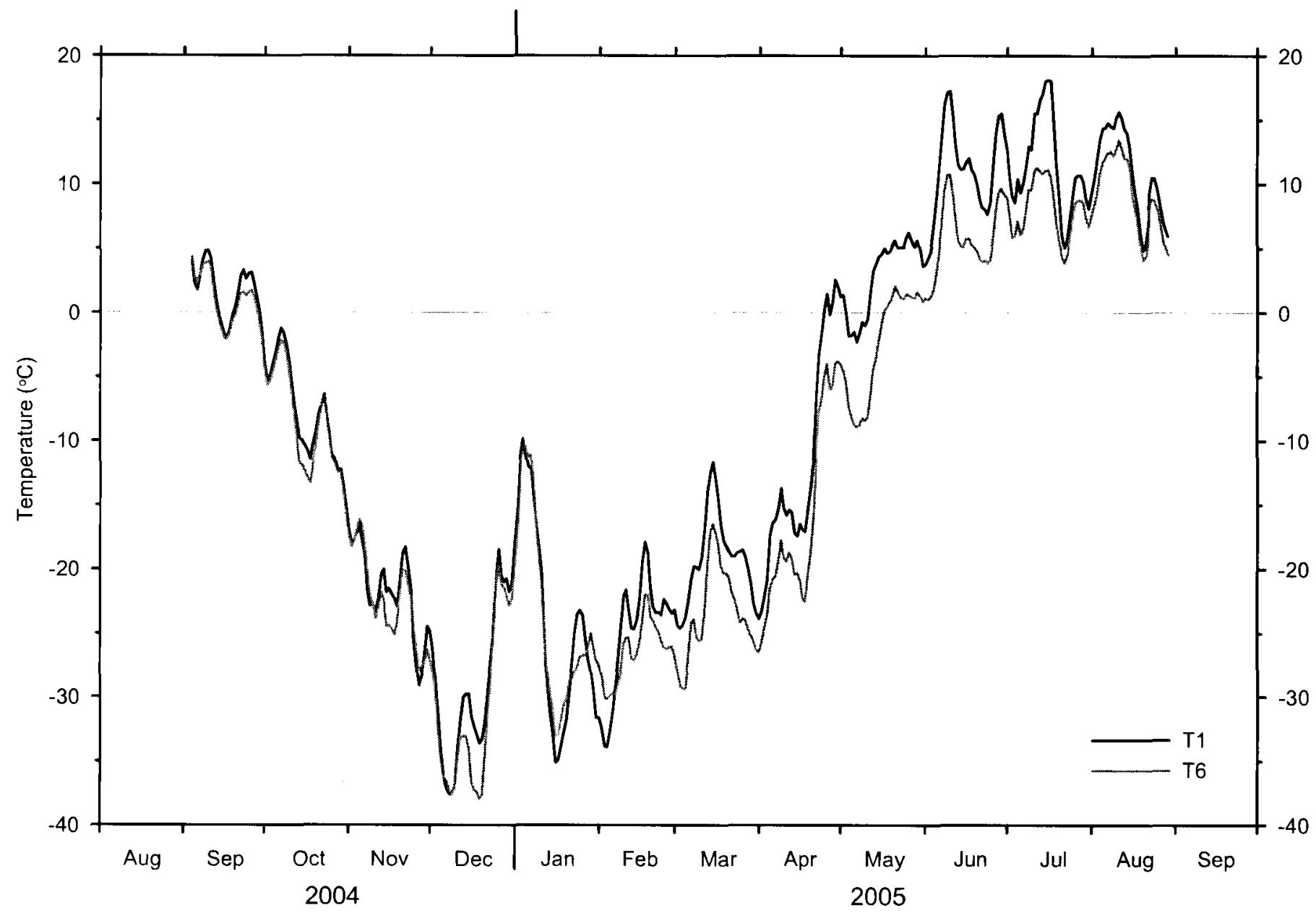

Figure 5.1 Air temperatures at T1 and T6, September 2004 - September 2005. The air temperature regimes for sites $\mathrm{T} 2, \mathrm{~T} 3, \mathrm{~T} 4$, and $\mathrm{T} 5$ lie within the regimes of $\mathrm{T} 1$ and $\mathrm{T} 6$, therefore, for clarity only the air temperature regimes at $\mathrm{T} 1$ and $\mathrm{T} 6$ are presented. Temperatures were recorded every 4 hours, but the lines represent 5-day running means. 
Table 5.1 Annual air and surface temperature summary statistics at sites T1 to T6, September 1, 2004 to September 1, 2005.

\begin{tabular}{|c|c|c|c|c|c|c|}
\hline & T1 & $\mathrm{T} 2$ & T3* & $\mathrm{T} 4$ & T5 & T6 \\
\hline \multicolumn{7}{|l|}{ Air } \\
\hline Mean $\left({ }^{\circ} \mathrm{C}\right)$ & -8.4 & -9.6 & -9.9 & -10.5 & -10.4 & -10.8 \\
\hline Standard deviation & 15.5 & 14.8 & 14.8 & 15.3 & 14.9 & 14.9 \\
\hline Maximum $\left({ }^{\circ} \mathrm{C}\right)$ & 22.4 & 18.6 & 17.5 & 16.9 & 16.4 & 16.0 \\
\hline Minimum $\left({ }^{\circ} \mathrm{C}\right)$ & -39.3 & -36.7 & -37.1 & -41.7 & -41.1 & -40.2 \\
\hline \multicolumn{7}{|l|}{ Surface } \\
\hline Mean $\left({ }^{\circ} \mathrm{C}\right)$ & -3.2 & -3.7 & -4.3 & -5.3 & -6.0 & -6.5 \\
\hline Standard deviation & 7.3 & 7.9 & 7.6 & 9.6 & 9.7 & 9.3 \\
\hline Maximum $\left({ }^{\circ} \mathrm{C}\right)$ & 11.6 & 11.4 & 10.7 & 11.4 & 10.2 & 9.7 \\
\hline Minimum $\left({ }^{\circ} \mathrm{C}\right)$ & -14.5 & -17.4 & -14.9 & -22.6 & -23.8 & -20.2 \\
\hline
\end{tabular}




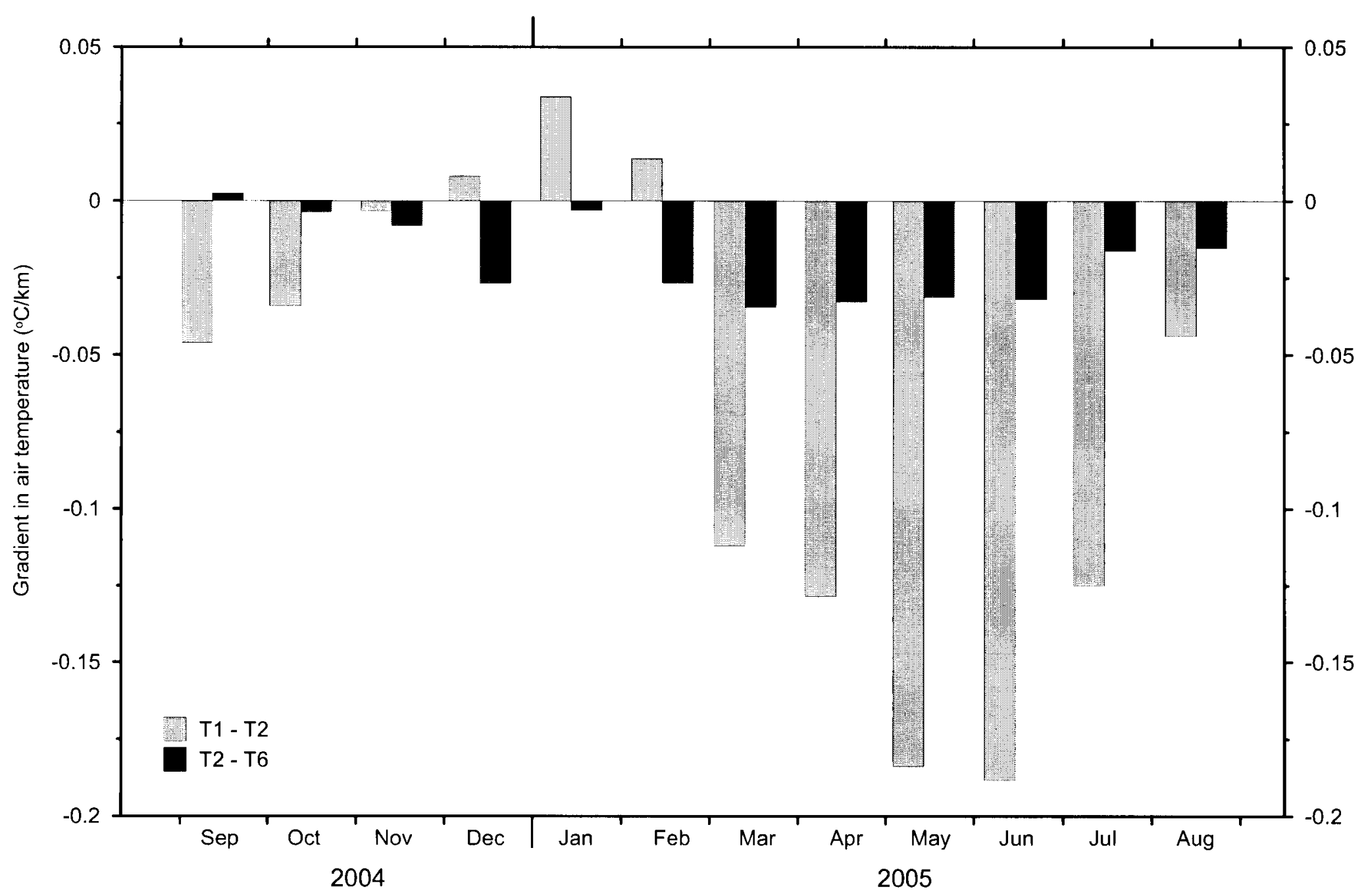

Figure 5.2 The gradient $\left({ }^{\circ} \mathrm{C} / \mathrm{km}\right)$ in air temperature between $\mathrm{T} 1$ and $\mathrm{T} 2$, and between $\mathrm{T} 2$ and T6, September 2004 September 2005. 
effect (see section 3.1.2), influencing the difference in air temperatures across treeline in the study area.

The gradient in early spring air temperatures along the transect was likely due to a difference in net radiation $\left(\mathrm{Q}^{*}\right)$ between the boreal forest site $(\mathrm{T} 1)$ and the shrub sites $(\mathrm{T} 2$, T3, T4, T5 and T6). Near Churchill, Manitoba, Lafleur et al. (1993) reported a four-fold increase in net radiation between an open-canopy forest site and a tundra site, when snow was on the ground. The difference was attributed to a lower albedo over the forest $(0.32)$ than over the tundra (0.78) (see section 2.3.1.2; Rouse, 1984a; Lafleur et al., 1993). There is a difference in albedo year round between forested and tundra sites, but the difference in net radiation is particularly pronounced prior to snowmelt during early spring when the sun angle is high and there is a large influx of solar radiation, due to an increase in the daily daylight hours (Rouse, 1984a).

In this study the tall shrubs at T2 were almost completely snow covered by early spring and there was no foliage on the branches, whereas at T1, dark spruce trees stood above the snow cover. The resulting large difference in albedo between the sites likely led to an elevated $Q^{*}$ at $T 1$ and subsequently higher air temperatures.

Mean air temperatures over the entire freezing-season (October to May) generally decreased northwards along the transect, primarily due to the difference in net radiation between the sites during late winter and early spring, as air conditions were similar along the transect during fall. Mean freezing-season air temperatures were warmest at T1 $\left(-16.6^{\circ} \mathrm{C}\right)$ and coldest at $\mathrm{T} 4\left(-19.1^{\circ} \mathrm{C}\right)$ (Figure 5.3a). 


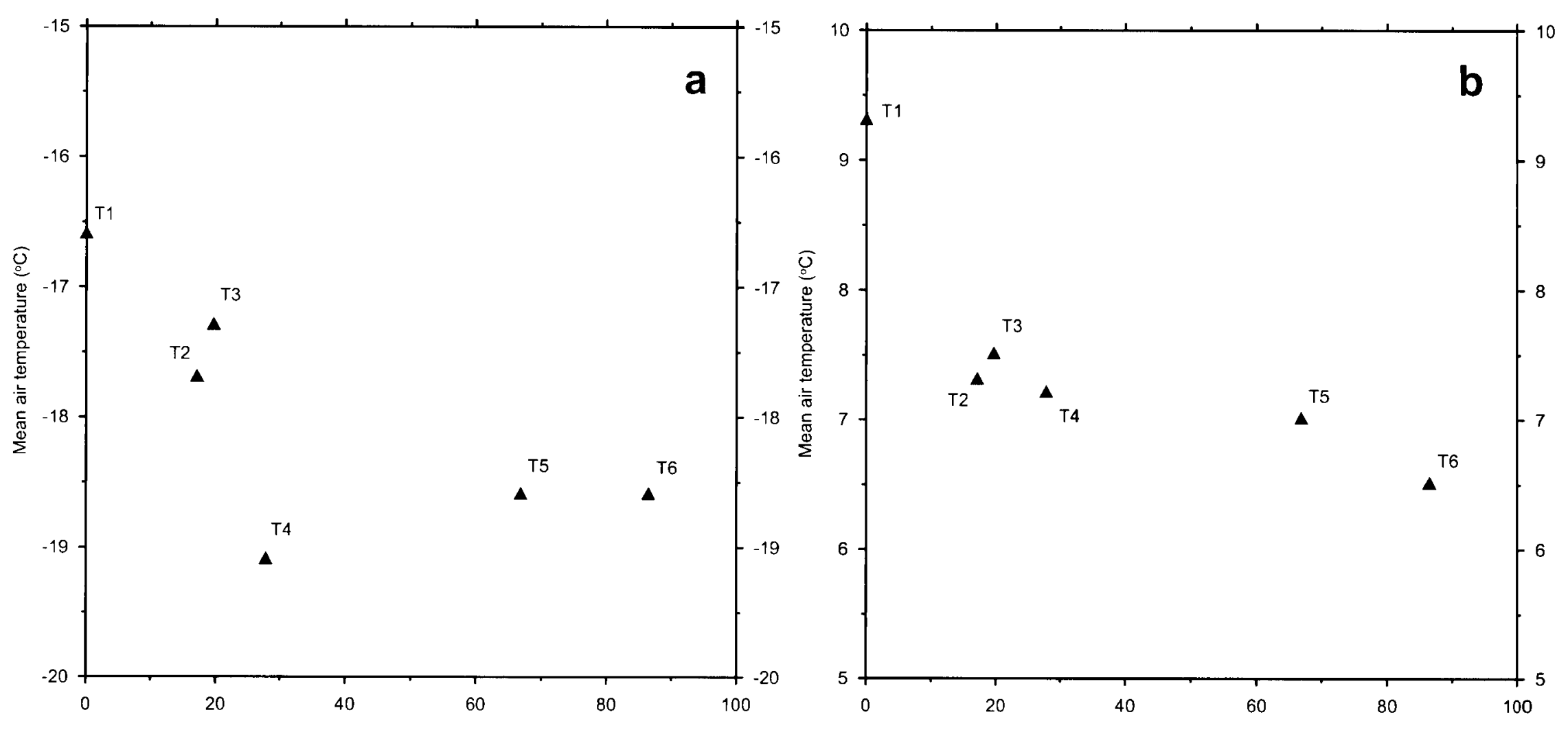

Figure 5.3 Mean air temperatures across the treeline transition for: a) freezing season, b) thawing season. 


\subsubsection{Thaw-season air temperatures}

Air temperatures were above $0^{\circ} \mathrm{C}$ at all sites from mid May to the end of the study period (Figure 5.1). Mean thaw-season air temperatures decreased northward along the treeline transect from $9.3^{\circ} \mathrm{C}$ at $\mathrm{T} 1$ to $6.5^{\circ} \mathrm{C}$ at $\mathrm{T} 6$ (Figure $5.3 \mathrm{~b}$ ). The change in mean thaw-season air temperature was greatest between $\mathrm{T} 1$ and $\mathrm{T} 2\left(2.1^{\circ} \mathrm{C}\right)$, temperatures were similar between $\mathrm{T} 2$ and $\mathrm{T} 5$, and mean thaw-season air temperatures decreased from $\mathrm{T} 5$ to T6 (Figure 5.3b).

The thaw-season air temperature gradient across the treeline transition was likely influenced by two different physical mechanisms. First, differences in net radiation between the sites were likely responsible for the steep decrease $\left(2.1^{\circ} \mathrm{C}\right)$ in mean thawseason temperatures at the southern end of the transect. The foliage of deciduous shrubs has a higher albedo than the darker spruce trees (Rouse, 1984a), so a difference in albedo and net radiation exists between forest and shrub sites during summer, even after snowmelt is complete. Data from a similar environment near Churchill, Manitoba, showed an $11 \%$ increase in net radiation between a tundra site $\left(751.5 \mathrm{MJ} \mathrm{m}^{-2}\right)$, and an open woodland site (836.7 $\mathrm{MJ} \mathrm{m}^{-2}$ ) during the snow-free period (Rouse, 1984a).

Second, the proximity of sites at the northern end of the transect to the coast likely resulted in cooler summer air temperatures. Burn (1997) investigated the summer air temperature gradient from Inuvik to the Beaufort Sea coast at lowland sites, west of the uplands investigated in this research, and attributed the northward decrease in summer air temperatures between Bar $\mathrm{C}$ and the coast to a coastal effect. During summer, air temperatures close to the coast are cooled by onshore winds blowing from the frigid sea. 
It was determined that the cooling influence extended $70 \mathrm{~km}$ inland and was particularly pronounced in June, when the ice pack was less than $20 \mathrm{~km}$ offshore (Burn, 1997).

The most northerly site (T6) was likely influenced by its proximity to the coast, as thaw-season air temperatures were similar at the shrub sites (T2 to T5) along the transect until within $50 \mathrm{~km}$ of the coast (Figure $5.3 \mathrm{~b}$ ). The decrease in thaw-season air temperatures between $\mathrm{T} 5$ and $\mathrm{T} 6$ cannot be explained by differences in net radiation between the sites as the vegetation cover between $\mathrm{T} 5$ and $\mathrm{T} 6$ was similar.

\subsection{Surface temperatures across treeline}

Annually, surface temperatures decreased northward along the treeline transect and were, on average, $3.3^{\circ} \mathrm{C}$ higher at $\mathrm{T} 1\left(-3.2^{\circ} \mathrm{C}\right)$ than at $\mathrm{T} 6\left(-6.5^{\circ} \mathrm{C}\right)$, slightly more than the difference in air temperatures $\left(2.5^{\circ} \mathrm{C}\right)$ (Table 5.1). Much of the difference in surface temperature along the transect occurred between the shrubby tussock tundra site (T3) and the shrub tundra site (T4), in association with the change in vegetation and snow cover between the sites. These differences are real because they are greater than the total potential measurement error due to the accuracy of the data loggers $\left(+/-1.0^{\circ} \mathrm{C}\right)$. Minimum surface temperatures were more variable along the transect than maximum surface temperatures, due to the variability of the snow cover (Table 5.1).

\subsubsection{Freezing-season surface temperatures across treeline}

Surface temperatures remained below $0^{\circ} \mathrm{C}$ at all sites from mid-September to early May (Figure 5.4). Surface temperatures dropped below $0^{\circ} \mathrm{C}$ at approximately the same date at all sites, as air temperatures along the transect fell below $0^{\circ} \mathrm{C}$ at 


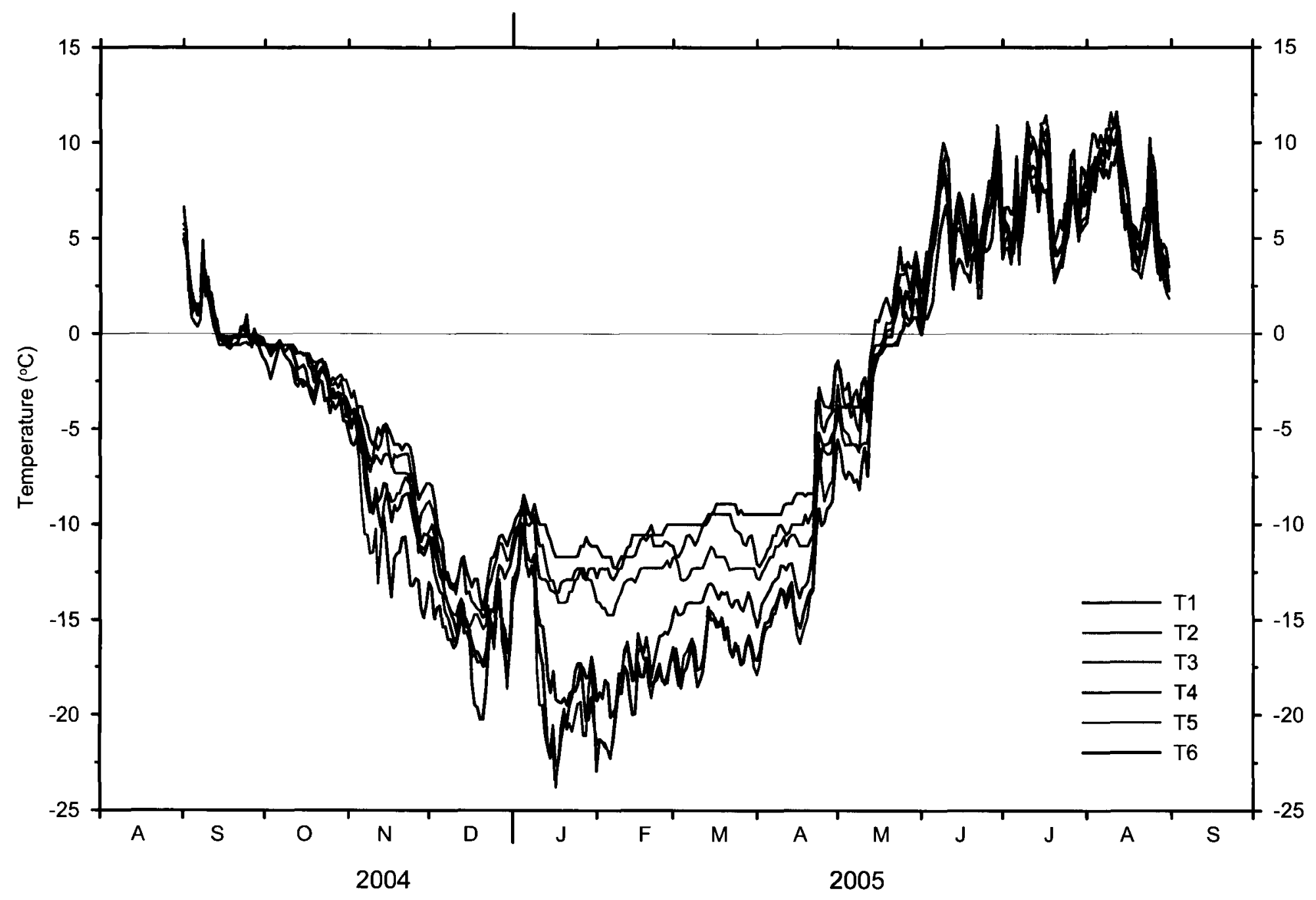

Figure 5.4 5-cm temperatures at sites T1 to T6, September 2004 - September 2005. Temperatures were recorded every 4-hours, but the lines represent the daily means. 
approximately the same date. Surface temperatures during fall were similar until late October (Figure 5.4), when temperatures began to diverge after snow had begun to accumulate at the sites. After the arrival of the snow cover, surface temperatures at the shrub tundra and low shrub tundra sites (T4 through T6) cooled much more rapidly than at sites $\mathrm{T} 1$ through T3, where deeper snow depths restricted heat loss from the ground (Figure 5.4).

During the freezing-season, fluctuations in surface temperature at the shrub tundra (T4) and low shrub tundra sites (T5 and T6) followed variations in air temperature more closely than sites with deeper snow cover (Figure 5.4). This was most evident during a warm period in late December and early January, where surface temperatures at T4 to T6 increased rapidly in contrast with sites south of T4 (Figure 5.4). Surface temperatures at T4 to T6 cooled quickly again in mid-January as air temperatures dropped. These data suggest that tundra soils respond more readily to changes in air temperature than forest soils.

Differences in surface temperatures along the transect were greatest from January to March (Figure 5.4). However, surface temperatures began to increase and converge in March and April in association with rising air temperatures, as tundra sites warmed more quickly than boreal and shrub sites due to the thinner snow cover (Figure 5.4). In early May, surface temperatures approached $0^{\circ} \mathrm{C}$, surface conditions were dominated by snowmelt and surface temperatures at the sites were similar (Figure 5.4).

During the freezing-season, surface temperatures along the transect were better correlated with mean end of winter snow depth (Spearman rank order; $\mathrm{r}=1.00 ; \mathrm{P}<$ $0.001 ; \mathrm{n}=6$ ), than freezing-season air temperature (Spearman rank order correlation; $\mathrm{r}=$ 
$0.67 ; \mathrm{P}<0.001 ; \mathrm{n}=6$ ), indicating that the variation in freezing-season surface temperatures along the transect was controlled by snow depth.

Mean freezing-season surface temperatures were warmest at $\mathrm{T} 1\left(-7.4^{\circ} \mathrm{C}\right)$ to $\mathrm{T} 3$ $\left(-8.4^{\circ} \mathrm{C}\right)$ (Figure 5.5a; Table 5.2), where snow depths along the transect were deepest. Surface temperatures were $2.3^{\circ} \mathrm{C}$ to $4.1^{\circ} \mathrm{C}$ lower at the shrub and low shrub tundra sites (T4 to T6), where mean end of winter snow depths were statistically significantly different (section 4.3.1). A steep decrease in freezing-season surface temperatures $\left(2.3^{\circ} \mathrm{C}\right.$ ) was observed between $\mathrm{T} 3$ and $\mathrm{T} 4$ (Figure $\left.5.5 \mathrm{a}\right), 7 \mathrm{~km}$ apart, in association with a difference of $20 \mathrm{~cm}$ in mean end of winter snow depth between the sites. In contrast, the difference between $\mathrm{T} 4$ and $\mathrm{T} 6,60 \mathrm{~km}$ apart, was less than $1.0^{\circ} \mathrm{C}$ (Figure 5.5a), and end of winter snow depths did not vary significantly between sites.

\subsubsection{Thawing-season surface temperatures}

Surface temperatures at the sites rose above $0^{\circ} \mathrm{C}$ within 10 days of each other in May (Figure 5.4). The number of days between air and surface temperatures rising above $0^{\circ} \mathrm{C}$ was greater at sites $\mathrm{T} 1$ to $\mathrm{T} 3$ (approximately 9 days), than at $\mathrm{T} 4$ to $\mathrm{T} 6$ (approximately 3 days), as more energy was required to melt the deeper snow south of T4.

Surface temperatures were much less variable between sites during the thawingseason than during the freezing-season (Figure 5.5). Surface temperatures varied less than $1.0^{\circ} \mathrm{C}$ between $\mathrm{T} 1$ and $\mathrm{T} 5$, indicating that warmer air temperatures at the southern end of the transect were offset by differences in surface and subsurface conditions at the sites.

Differences in vegetation cover, organic-layer thickness, and surface moisture contributed to the trend in thawing-season surface temperatures along the transect 

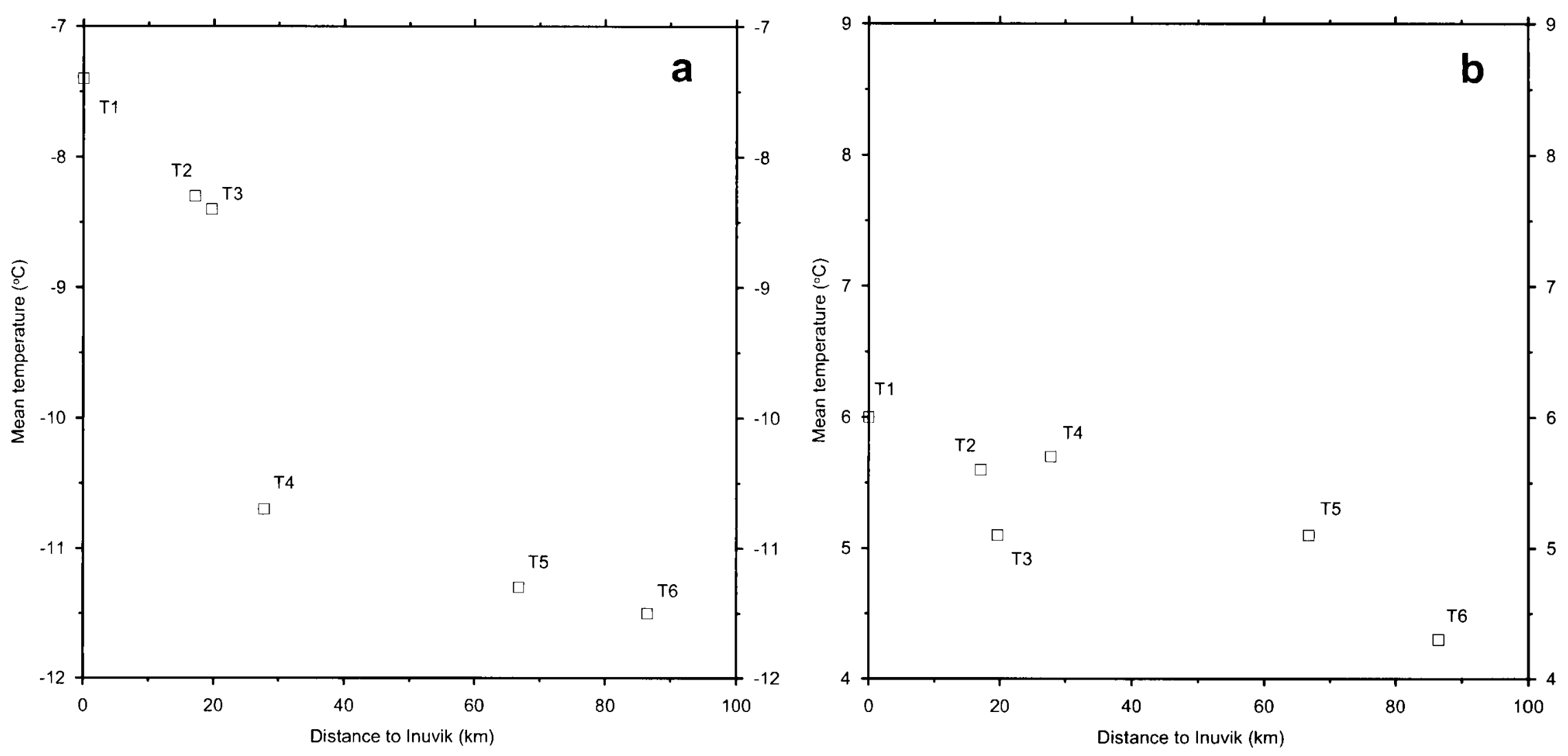

Figure 5.5 Mean 5-cm temperatures across the treeline transition for: a) freezing season, b) thawing season. 
Table 5.2 Annual, freezing-season, and thawing-season surface offsets at T1 to T6, September 1, 2004 to September 1, 2005.

\section{$\mathrm{T} 1$} $\mathrm{T} 2$ T3 T4 T5 T6

\section{Annual}

Mean air temperature $\left({ }^{\circ} \mathrm{C}\right)$ Mean surface temperature $\left({ }^{\circ} \mathrm{C}\right)$

Surface offset

$-8$.

$-8.3$

$-3.2$

5.1

$-9.5$

$-9.8$

$-4.3$

$-10.5$

$-5.3$

5.2

$-10.4$

$-6.0$

$-10.8$

5.8

5.6

4.4

4.3

Freezing season

Mean air temperature $\left({ }^{\circ} \mathrm{C}\right)$

Mean surface temperature $\left({ }^{\circ} \mathrm{C}\right)$

Surface offset

$-16.6 \quad-17.7$

$-17.4$

$-19.1$

$-18.6$

$-18.6$

$-7$

9.2

$-8.3$

$-8.4$

$-10.7$

$-11.3$

$-11.5$

Thawing season

Mean air temperature $\left({ }^{\circ} \mathrm{C}\right)$

Mean surface temperature $\left({ }^{\circ} \mathrm{C}\right)$

$9.3 \quad 7.3$

$6.0 \quad 5.6$

7.5

5.1

7.2

5.7

7.0

5.1

6.5

$-3.3 \quad-1.7$

$-2.4$

$-1.5$

Note: Accuracy of the thermistors is $+/-0.5^{\circ} \mathrm{C}$, therefore accuracy of the surface offset is $+/-1.0^{\circ} \mathrm{C}$ (see section 3.4.2). 
through differences in the near-surface thermal diffusivity and canopy interception of incoming radiation. In the early part of the thawing-season, surface warming is hampered by a steep temperature gradient and consumption of latent heat (Karunaratne and Burn, 2004). Once the frost table is below the depth of diurnal variation, surface temperatures are controlled by air temperatures (Karunaratne and Burn, 2004). The large difference in thawing-season air temperatures between $\mathrm{T} 1$ and $\mathrm{T} 2$ was not registered at the surface, as surface warming was hindered at $\mathrm{T} 1$ by the low thermal diffusivity of the thick moss ground cover. Surface temperatures rose earlier and more quickly at $T 2$, due to the low thermal diffusivity associated with the thin organic-layer (Figure 5.6). Surface temperatures at $\mathrm{T} 3$, the wettest site, were $0.5^{\circ} \mathrm{C}$ lower than at $\mathrm{T} 2$ and $\mathrm{T} 4$ (Figure 5.5b), due to the high heat capacity of the surface and because a larger proportion of net radiation at the site was directed towards $Q_{L}$. Thawing-season surface temperatures were lowest at T6 in association with the lowest thawing-season air temperatures.

Interception of incoming radiation by the vegetation cover is represented by the structural complexity of the vegetation (SCX). A rank order of the physical characteristics of the sites (Table 5.3) shows that SCX was largest at the southern end of the transect, between $\mathrm{T} 1$ and $\mathrm{T} 4$, therefore the shading of the ground surface was greater at the southern end of the transect, and the proportion of net radiation directed to the ground heat flux was reduced. The increase in shading of the ground surface at the southern end of the transect likely decreased the difference in thawing-season surface temperatures along the transect, as a larger proportion of net radiation was directed towards the ground heat flux at the northern end of transect. 


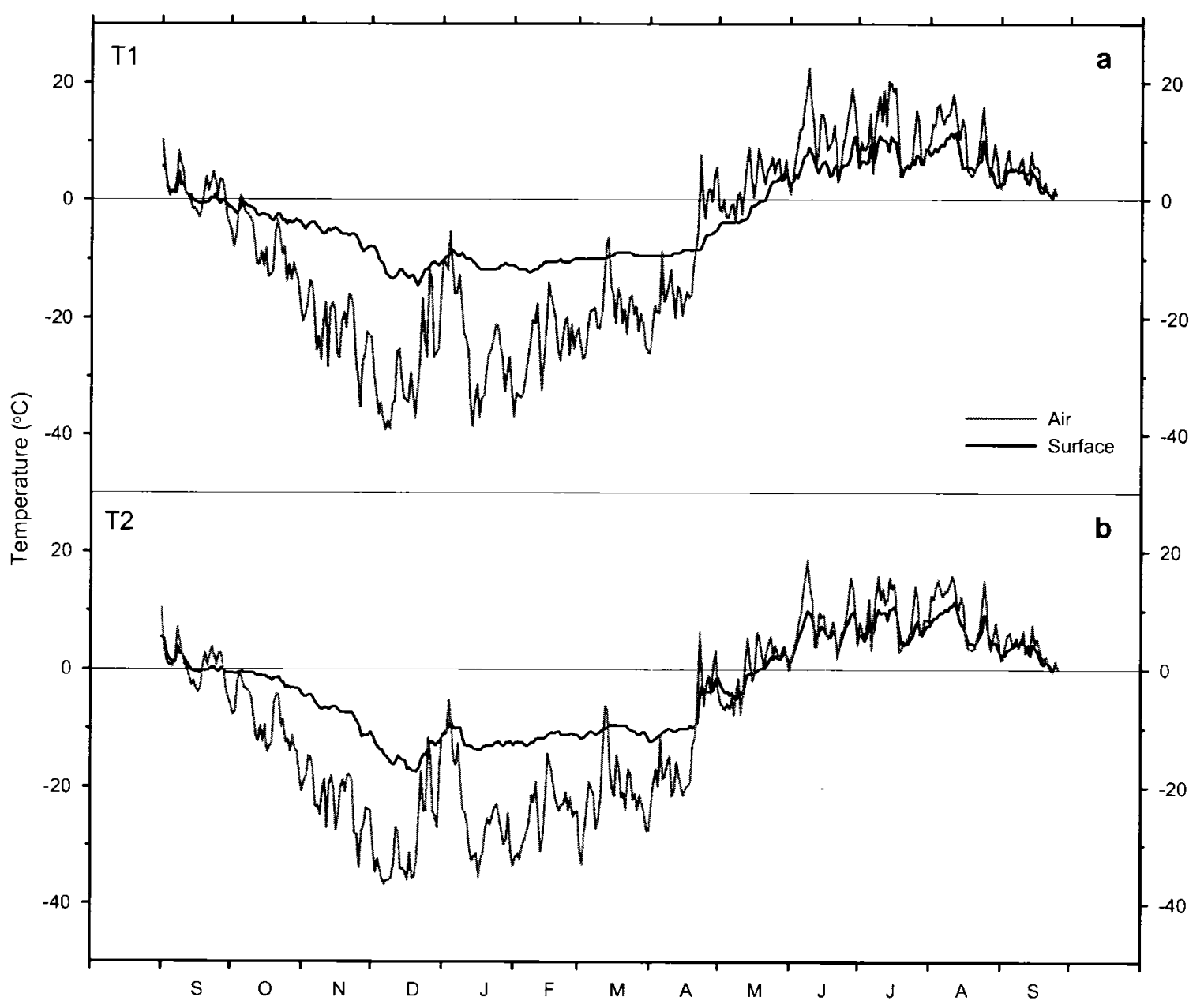

Figure 5.6 Air and 5-cm temperatures at: a) T1; and b) T2, September 2004 to October 2005. 
Table 5.3 Ranking of the study sites by physical characteristics

\begin{tabular}{|c|c|c|c|c|c|c|c|c|c|}
\hline $\begin{array}{c}\text { Mean } \\
\text { vegetation } \\
\text { height }\end{array}$ & $\begin{array}{l}\text { Mean } \\
\text { SCX }\end{array}$ & $\begin{array}{l}\text { Mean end } \\
\text { of winter } \\
\text { snow depth }\end{array}$ & $\begin{array}{l}\text { Active } \\
\text { layer } \\
\text { VMC* }\end{array}$ & $\begin{array}{c}\text { Surface } \\
\text { moisture }\end{array}$ & $\begin{array}{c}\text { Organic } \\
\text { layer } \\
\text { thickness }\end{array}$ & $\begin{array}{l}\text { Freezing } \\
\text { season air } \\
\text { temperature }\end{array}$ & $\begin{array}{l}\text { Freezing } \\
\text { season } \\
\text { surface } \\
\text { temperature }\end{array}$ & $\begin{array}{l}\text { Thawing } \\
\text { season air } \\
\text { temperature }\end{array}$ & $\begin{array}{l}\text { Thawing } \\
\text { season } \\
\text { surface } \\
\text { temperature }\end{array}$ \\
\hline T1 & $\mathrm{T} 2$ & $\mathrm{~T} 1, \mathrm{~T} 2, \mathrm{~T} 3$ & $\mathrm{~T} 1, \mathrm{~T} 2, \mathrm{~T} 3$ & T3 & T3 & T1 & T1 & T1 & $\mathrm{T} 1, \mathrm{~T} 2, \mathrm{~T} 4$ \\
\hline $\mathrm{T} 2$ & $T 1, T 4$ & T4 & $\mathrm{T} 4, \mathrm{~T} 6$ & $\mathrm{~T} 1, \mathrm{~T} 2, \mathrm{~T} 5, \mathrm{~T} 6$ & $\mathrm{~T} 1, \mathrm{~T} 5, \mathrm{~T} 6$ & $\mathrm{~T} 2, \mathrm{~T} 3$ & $\mathrm{~T} 2, \mathrm{~T} 3$ & $\mathrm{~T} 2, \mathrm{~T} 3, \mathrm{~T} 4, \mathrm{~T} 5$ & $\mathrm{~T} 3, \mathrm{~T} 5$ \\
\hline T3 & T3 & $\mathrm{T} 5, \mathrm{~T} 6$ & T5 & T4 & T4 & T5,T6 & T4 & T6 & T6 \\
\hline $\mathrm{T} 4$ & $\mathrm{~T} 5, \mathrm{~T} 6$ & & & & T2 & T4 & T5,T6 & & \\
\hline T5, T6 & & & & & & & & & \\
\hline
\end{tabular}

Sites in the same row indicate the same rank order. $\mathrm{VMC}^{*}=$ Volumetric moisture content. 


\subsection{Air and surface temperatures across treeline}

\subsubsection{The surface offset}

The surface offset represents the difference between the annual mean temperature at the ground surface and the annual mean air temperature (Riseborough and Smith, 1998), but it can also be calculated on a seasonal basis. Annually, surface temperatures were higher than air temperatures at all sites (Table 5.2), indicating that freezing season conditions exert a greater influence on annual surface temperatures than thawing season conditions, as surface temperatures were higher than air temperatures during the freezing season and lower than air temperatures during the thawing season. The annual surface offset varied along the transect between $4.3^{\circ} \mathrm{C}$ at $\mathrm{T} 6$ and $5.8^{\circ} \mathrm{C}$ at $\mathrm{T} 2$ and was higher at sites $\mathrm{T} 1$ to $\mathrm{T} 4$, than at $\mathrm{T} 5$ and $\mathrm{T} 6$ (Table 5.2). These differences are real as the error associated with the surface offset is likely less than $+/-1.0^{\circ} \mathrm{C}$ (see section 5.1 ).

The daily surface offset is plotted in Figure 5.7 for the end members of the transect, $\mathrm{T} 1$ and $\mathrm{T} 6$, to determine the variation in the surface offset throughout the study period. Snow conditions had a considerable influence on the surface offset during the freezing-season, as the surface offset was consistent along the transect during fall prior to the arrival of the snow cover (Figure 5.7). With the arrival of the snow cover in late October, the magnitude of the surface offset increased and differences in the surface offset appeared along the transect (Figure 5.7). During the freezing-season the surface offset was largest between T1 and T3 (Table 5.2), as surface cooling was inhibited by deep snow depths at the sites. The magnitude of the surface offset was greatest in late November and early December (Figure 5.7) as air temperatures cooled more rapidly than 


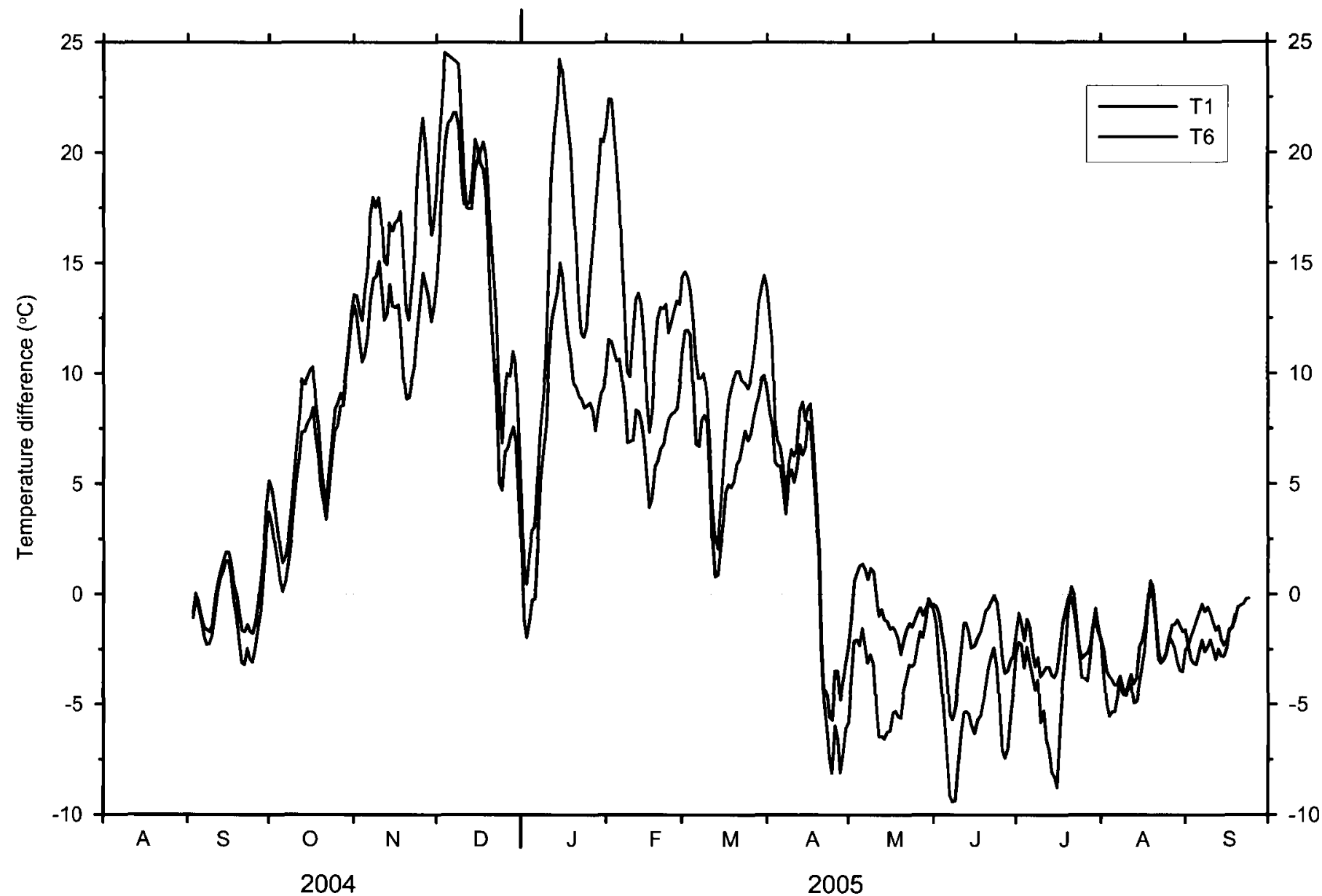

Figure 5.7 Five-day running mean of daily surface offset (surface temperature - air temperature) at $\mathrm{T} 1$ and $\mathrm{T} 6$ during the study period. 
soil temperatures. The difference in surface offset between sites was greatest in January and February, when the snow pack at the sites was well established and air temperatures were coldest. The surface offset decreased along the transect from mid January to mid April as air temperatures warmed more rapidly than surface temperatures along the transect.

In April, air temperatures exceeded surface temperatures and the surface offset was negative until the end of the study period (Figure 5.7). The magnitude of the summer surface offset decreased as the thaw season progressed (Figure 5.7) and the thaw front passed the depth of diurnal variation (Karunaratne and Burn, 2004). Surface temperatures were cooler than air temperatures during summer, likely because the surface temperature measurement was recorded at a depth of $5 \mathrm{~cm}$ and steep gradients in temperature and vapour pressure exist near the ground surface in peaty soils (Hinkel and Outcalt, 1994).

The magnitude of the surface offset was smaller during the thawing-season than during the freezing-season, as the buffering effect of surface conditions was reduced without the snow cover. The thaw season surface offset was influenced by both surface and subsurface conditions, including vegetation cover, surface moisture, and the thickness of the organic-layer. During the thawing season, the surface offset was largest at $\mathrm{T} 1$, as high air temperatures were offset by the interception of incoming radiation by tall spruce trees and the low thermal diffusivity of the thick moss ground cover (Table 5.2). 


\subsubsection{N-factors}

Freezing $\left(\mathrm{n}_{\mathrm{f}}\right)$ and thawing $\left(\mathrm{n}_{\mathrm{t}}\right) \mathrm{n}$-factors were calculated for all of the study sites during the freezing and thawing seasons using air and surface freezing and thawing degree-days (Table 5.4). The freezing and thawing seasons were defined by surface temperatures, following Karunaratne and Burn (2004).

The length of the freezing season was similar at all sites, as the length varied less than $5 \%$ between sites, irrespective of distance from Inuvik (Table 5.4). Air freezing degree days varied by $13 \%$ along the transect, but, the variation was minimal compared to the variation in freezing degree days at the ground surface $(56 \%)$, therefore variations in $\mathrm{n}_{\mathrm{f}}$ were predominately controlled by surface freezing degree days (Table 5.4). Freezing $\mathrm{n}$-factors increased along the transect, from 0.45 at $\mathrm{T} 1$ to 0.62 at $\mathrm{T} 6$, in association with the decrease in snow depth along the transect (Table 5.4). Values of $n_{f}$ varied little from $\mathrm{T} 1$ to $\mathrm{T} 3$ ( 0.45 to 0.48$)$ and from $\mathrm{T} 4$ to $\mathrm{T} 6(0.56$ to 0.62$)$, because snow depths were similar at these sites (see section 4.3.1). These results support the findings of Taylor (1995) who determined that the freezing n-factor was controlled by snow depth.

Thawing $\mathrm{n}$-factors were variable along the treeline transect and were dependent on the vegetation cover and soil conditions at the sites. The thawing n-factor was lowest at $\mathrm{T} 1(0.64)$, as tall spruce trees at the site intercepted much of the incoming radiation and the ground was covered by a thick moss layer. The thawing n-factor was also low at T3 (0.68), the wettest site, because the heat capacity of the surface was high. At T2 and T4, where mineral soil was close to the surface and the organic-layer was thin, the thawing nfactor was high (Table 5.4). 
Table 5.4 Freezing and thawing n-factors for the study sites.

\begin{tabular}{|c|c|c|c|c|c|c|}
\hline & $\mathrm{T} 1$ & $\mathrm{~T} 2$ & $\mathrm{~T} 3$ & $\mathrm{~T} 4$ & T5 & T6 \\
\hline Freezing season 2004-05 & Sept. 14 to May 21 & Sept. 14 to May 18 & Sept. 13 to May 24 & Sept. 14 to May 14 & Sept. 14 to May 18 & Sept. 14 to May 23 \\
\hline FDDair & 4145 & 4360 & 4399 & 4651 & 4600 & 4680 \\
\hline FDDsurface & 1855 & 2044 & 2120 & 2607 & 2797 & 2893 \\
\hline Freezing n-factor & 0.45 & 0.47 & 0.48 & 0.56 & 0.61 & 0.62 \\
\hline Thawing season 2005 & May 22 to Sept.25 & May 19 to Sept.26 & May 25 to Sept. 18 & May 15 to Sept.21 & May 19 to Sept. 17 & May 24 to Sept. 21 \\
\hline TDDair & 1178 & 951 & $867^{\star}$ & 908 & 848 & 781 \\
\hline TDDsurface & 750 & 725 & $588^{\star}$ & 728 & 627 & 517 \\
\hline Thawing $n$-factor & 0.64 & 0.76 & $0.68^{*}$ & 0.80 & 0.74 & 0.66 \\
\hline
\end{tabular}

*missing T3 data estimated from Aug.15 to end of thaw season. See section 3.4.3 in the text for details. 


\subsection{Ground thermal regime}

The ground thermal regime differs between study sites primarily due to differences in snow depth between sites, but minor differences in subsurface conditions between sites also contribute to differences in the ground thermal regime, particularly during freezing and thawing of the active-layer.

\subsubsection{Active-layer temperatures across treeline $\left(T_{50}\right)$}

Temperatures at $50 \mathrm{~cm}$ depth $\left(\mathrm{T}_{50}\right)$ dropped below $0^{\circ} \mathrm{C}$ at all sites between September 5 and September 15 during the study period, except at $\mathrm{T} 6$, where $\mathrm{T}_{50}$ was in permafrost (Figure 5.8). The zero curtain at the sites varied between 53 and 61 days (Table 5.5) and was dependent on subsurface soil conditions, snow depths, and the thickness of the active layer at the sites. Snow depths were not recorded at the sites during fall, but the snow pack did not begin to accumulate at Inuvik or Tuktoyaktuk until mid to late October (Environment Canada, 2005). The zero curtain was shortest (53 days) and ended earliest at T5 (Oct. 28), due to the thin snow cover and shallow activelayer, and the zero curtain was longest (61 days) and ended latest at T3 (Nov. 13), the wettest site (Table 5.5).

Ground temperatures at $50 \mathrm{~cm}$ depth decreased rapidly at all sites after freezeback of the active-layer (Figure 5.8). The rate of cooling $\left({ }^{\circ} \mathrm{C} /\right.$ day) was dependent on the thermal gradient within the soil, which is influenced by snow cover and soil conditions at the sites. The rate of cooling at $\mathrm{T}_{50}$ was greater at sites $\mathrm{T} 4$ to $\mathrm{T} 6\left(0.14\right.$ to $0.16^{\circ} \mathrm{C} /$ day $)$ than at $\mathrm{T} 1$ to $\mathrm{T} 3\left(0.09\right.$ to $0.12^{\circ} \mathrm{C} /$ day $)$, due to the thinner snow covers. 


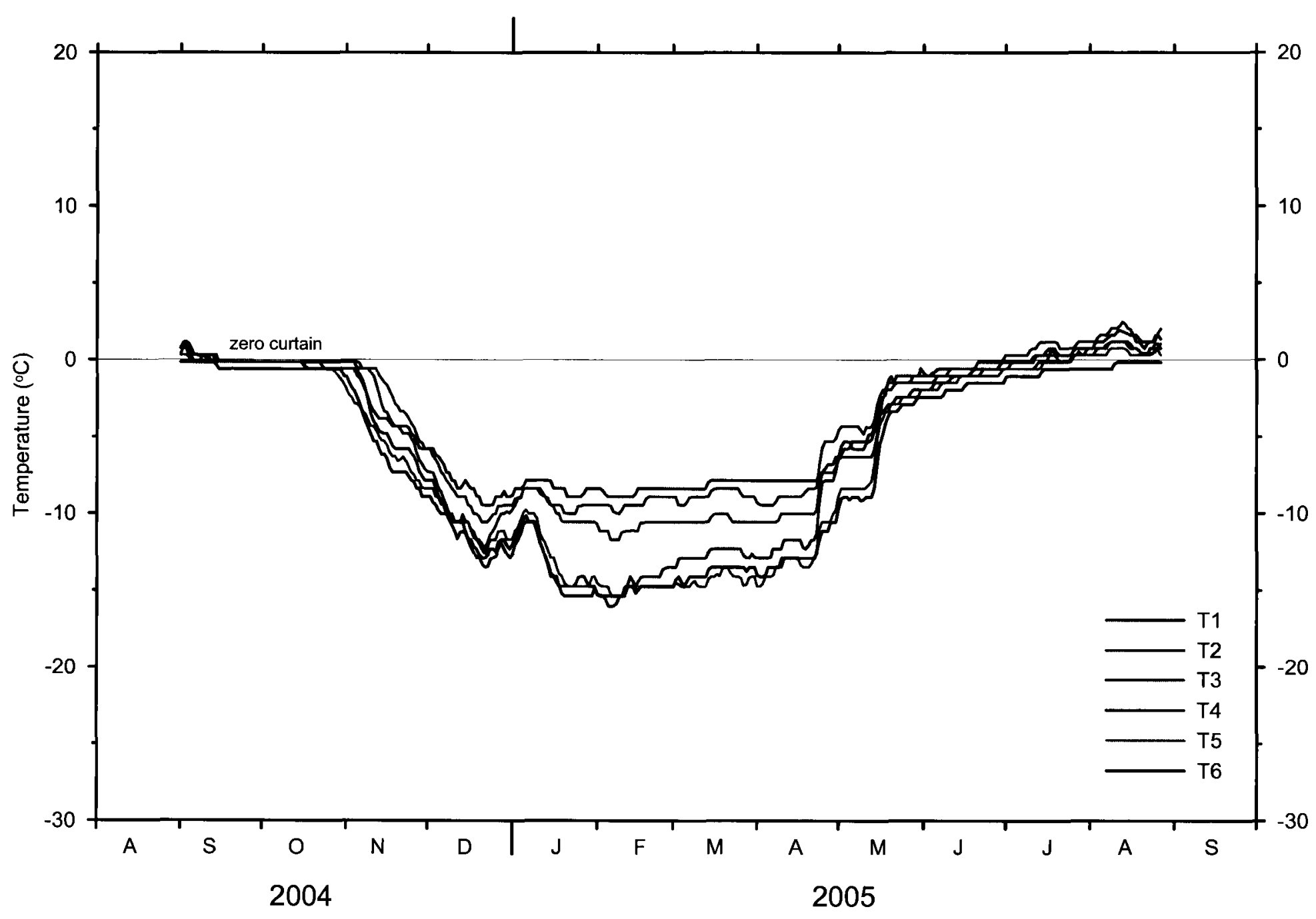

Figure 5.8 50-cm ground temperatures at T1 to T6, September $2004-2005$. Temperatures were recorded every 4 hours, but the lines represent the daily means. 
Table 5.5 Freezeback dates and zero curtain length at $5 \mathrm{~cm}, 50 \mathrm{~cm}$ and $100 \mathrm{~cm}$ below the surface for sites T1 to T6.

\begin{tabular}{|c|c|c|c|c|c|c|}
\hline & T1 & $\mathrm{T} 2$ & T3 & $\mathrm{T} 4$ & T5 & T6 \\
\hline \multicolumn{7}{|l|}{ Surface $(5 \mathrm{~cm})$} \\
\hline Date $<0^{\circ} \mathrm{C}$ & Sep. 14 & Sep. 14 & Sep. 13 & Sep. 14 & Sep. 14 & Sep. 14 \\
\hline Date of freezeback of surface & Sep. 14 & Sep. 14 & Sep. 22 & Sep. 17 & Sep. 25 & Sep. 17 \\
\hline Length of fall zero curtain & 0 & 0 & 9 & 3 & 11 & 3 \\
\hline Length of spring zero curtain & 3 & 3 & 6 & 0 & 2 & 3 \\
\hline Temperature amplitude & 26.1 & 28.8 & 25.6 & 34.0 & 34.0 & 29.9 \\
\hline \multicolumn{7}{|l|}{$50 \mathrm{~cm}$} \\
\hline Date $<0^{\circ} \mathrm{C}$ & Nov. 4 & Nov. 10 & Nov. 13 & Nov. 6 & Oct. 28 & N/A \\
\hline Length of fall zero curtain & 60 & 56 & 61 & 53 & 53 & N/A \\
\hline Length of spring zero curtain & 34 & 19 & 23 & 22 & 26 & N/A \\
\hline Temperature amplitude & 10.6 & 14.7 & 12.9 & 17.9 & 16.1 & 15.2 \\
\hline \multicolumn{7}{|l|}{$100 \mathrm{~cm}$} \\
\hline Date of freezback at depth & Nov. 6 & Nov. 9 & Nov. 16 & Nov. 9 & Oct. 29 & Nov. 1 \\
\hline Number of days for AL freezeback & 54 & 57 & 65 & 57 & 46 & 49 \\
\hline Temperature amplitude & 7.2 & 7.8 & 8.4 & 12.4 & 12.4 & 11.9 \\
\hline
\end{tabular}


The trend in winter $\mathrm{T}_{50}$ between sites along the treeline transect was similar to the trend in winter surface temperatures at the sites (Figures 5.4 and 5.8), except that the daily fluctuation in temperatures is less due to damping with depth. Winter $\mathrm{T}_{50}$ was highest at $\mathrm{T} 1$ to $\mathrm{T} 3$ in association with the warmest surface temperatures and deepest snow depths. This shows that any differences in air and soil conditions between sites at the southern end of the transect were overridden by the difference in snow depth between sites. At the northern end of the transect, $\mathrm{T} 4$ to $\mathrm{T} 6$, snow depths were thinner and $\mathrm{T}_{50}$ responded to differences in air and soil conditions between sites. For example, the minimum $\mathrm{T}_{50}$ was observed at $\mathrm{T} 4$, where winter air temperatures were the coldest, even though mean snow depth was greater than at T5 and T6.

Temperatures at $50 \mathrm{~cm}$ below the ground surface began to increase at all sites in mid-April in association with warming air temperatures and a reversal of the thermal gradient within the active-layer (Figure 5.8). The difference in $\mathrm{T}_{50}$ between sites persisted until late May when $\mathrm{T}_{50}$ at the sites converged near $0^{\circ} \mathrm{C}$, following the disappearance of the snow cover. Once the depth of thaw had penetrated to $50 \mathrm{~cm}$, differences in $\mathrm{T}_{50}$ between sites became more pronounced. $\mathrm{T} 2$ and $\mathrm{T} 4$ were the warmest sites during summer, due to thin organic layers and dry surface conditions. Differences in $\mathrm{T}_{50}$ along the transect during summer were small compared to winter differences, as the thawing-season was shorter and $\mathrm{T}_{50}$ was constrained by latent heat effects for much of the thawing-season.

\subsubsection{Top of permafrost temperatures}

Temperatures at $100 \mathrm{~cm}$ below the ground surface $\left(T_{100}\right)$ were recorded in permafrost at all sites along the treeline transect, and are considered to be the temperature 
at the top of permafrost (TTOP) (Figure 5.9; see section 3.3.3). The thermal regime at $\mathrm{T}_{100}$ was similar to that at $\mathrm{T}_{50}$, except that the magnitude and amplitude of temperatures recorded over the year was less at $\mathrm{T}_{100}$ (Table 5.5 and 5.6).

At an annual scale, $\mathrm{T}_{100}$ decreased northward along the treeline transect (Table 5.6). Annual mean $\mathrm{T}_{100}$ was highest at $\mathrm{T} 1\left(-4.0^{\circ} \mathrm{C}\right)$ and $\mathrm{T} 2\left(-4.1^{\circ} \mathrm{C}\right)$, in association with the highest surface and active-layer temperatures.

A steep decrease $\left(1.8^{\circ} \mathrm{C}\right)$ in annual mean $\mathrm{T}_{100}$ occurred between $\mathrm{T} 2$ and $\mathrm{T} 4$, due to a steep decrease in snow depths between the sites (Table 5.6). There was little change in annual mean $\mathrm{T}_{100}$ between $\mathrm{T} 4$ and $\mathrm{T} 6$, where snow depths were similar.

Summer $\mathrm{T}_{100}$ was similar at the sites (Figure 5.9), as a zero curtain persisted throughout the summer at all sites, and $\mathrm{T}_{100}$ was restricted from warming above $0^{\circ} \mathrm{C}$ due to the high ice content of the top of permafrost.

Annual mean temperatures at the surface, $50 \mathrm{~cm}$, and $100 \mathrm{~cm}$ decreased northwards, in association with the decrease in mean end of winter snow depths along the transect. This suggests that winter conditions are the dominant influence on the annual ground thermal regime along the transect. At an annual scale along the transect, soil conditions had a lesser influence on the differences in the ground thermal regime than did surface conditions, as the order of active-layer and permafrost temperatures did not vary from the order of surface temperatures.

\subsection{Thermal offset}

The thermal offset represents the difference between the annual mean temperature at the top of permafrost and the annual mean temperature at the ground surface (Burn and 


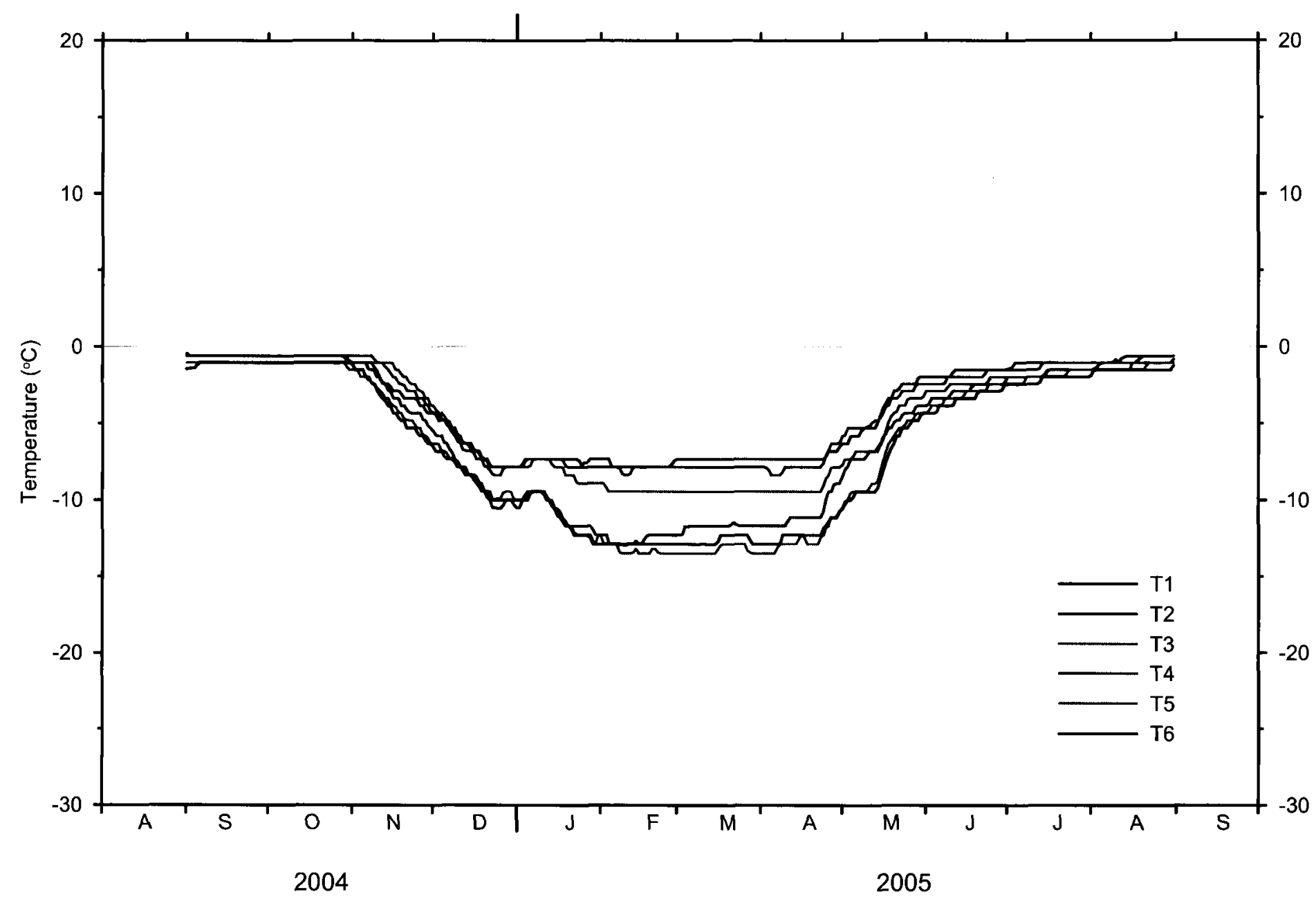

Figure 5.9 Temperatures at the top of permafrost at sites T1 to T6, September $2004-2005$. Temperatures were recorded every 4 hours, but the lines represent the daily means. 
Table 5.6 Annual mean surface temperatures, $50 \mathrm{~cm}$ temperatures, $100 \mathrm{~cm}$ temperatures, and thermal offsets at T1 to T6, September 1, 2004 to September 1, 2005.

\begin{tabular}{lcccccc}
\hline & $\mathrm{T} 1$ & $\mathrm{~T} 2$ & $\mathrm{~T} 3^{*}$ & $\mathrm{~T} 4$ & $\mathrm{~T} 5$ & $\mathrm{~T} 6$ \\
\hline & & & & & & \\
Annual & & & & & & \\
Annual mean surface temperature $\left({ }^{\circ} \mathrm{C}\right)$ & -3.2 & -3.7 & -4.3 & -5.3 & -6.0 & -6.5 \\
Annual mean 50-cm temperature $\left({ }^{\circ} \mathrm{C}\right)$ & -3.9 & -4.1 & -4.6 & -5.9 & -6.4 & -6.8 \\
Annual mean temperature $100 \mathrm{~cm}\left({ }^{\circ} \mathrm{C}\right)$ & -4.0 & -4.1 & -4.8 & -5.9 & -6.5 & -6.5 \\
Annual thermal offset & -0.8 & -0.4 & -0.5 & -0.6 & -0.5 & $-0.3^{\#}$ \\
& & & & & & \\
Freezing season & & & & & & \\
Mean surface temperature $\left({ }^{\circ} \mathrm{C}\right)$ & -7.4 & -8.3 & -8.4 & -10.7 & -11.3 & -11.5 \\
Mean 50-cm temperature $\left({ }^{\circ} \mathrm{C}\right)$ & -5.7 & -6.3 & -6.6 & -8.7 & -9.2 & -9.3 \\
Mean $100 \mathrm{~cm}$ temperature $\left({ }^{\circ} \mathrm{C}\right)$ & -5.2 & -5.3 & -6.0 & -7.7 & -8.4 & -8.3 \\
Thermal offset & 2.2 & 3.0 & 2.4 & 3.0 & 2.9 & $2.2^{\#}$ \\
& & & & & & \\
Thawing season & & & & & & \\
Mean surface temperature $\left({ }^{\circ} \mathrm{C}\right)$ & 6.0 & 5.6 & 5.1 & 5.7 & 5.1 & 4.3 \\
Mean $50-\mathrm{cm}$ temperature $\left({ }^{\circ} \mathrm{C}\right)$ & 0.1 & 0.4 & -0.2 & -0.2 & -0.5 & -1.1 \\
Mean $100 \mathrm{~cm}$ temperature $\left({ }^{\circ} \mathrm{C}\right)$ & -1.2 & -1.4 & -1.7 & -2.1 & -2.3 & -2.3 \\
Thermal offset & -7.2 & -7.0 & -6.8 & -7.8 & -7.4 & $-5.4{ }^{\#}$ \\
\hline
\end{tabular}

*Missing thaw season data at T3 was estimated from existing data at T2 and T3, see section 3.4.3 in text for details.

${ }^{\#}$ Thermal offset at $\mathrm{T} 6$ was calculated using $\mathrm{T}_{50}$, as $\mathrm{T}_{50}$ was within permafrost at the site. Note: Accuracy of the thermistors is $+/-0.5^{\circ} \mathrm{C}$, therefore accuracy of the thermal offset is $+/-1.0^{\circ} \mathrm{C}$ (see section 3.4.2). 
Smith, 1988). The thermal offset is generally negative, as the thermal conductivity of soil is greater when frozen than thawed.

The thermal offsets for all of the sites were within the margin of error $\left(+/-1.0^{\circ} \mathrm{C}\right)$ of the thermal offset calculation, therefore it was not possible to determine if differences in the thermal offset existed between sites (Table 5.6). The thermal offsets measured at the sites are comparable to values recorded by Romanovsky and Osterkamp (1995) on the Alaska Coastal Plain. Romanovsky and Osterkamp (1995) determined that summer surface temperature conditions also had a significant effect on the thermal offset and that the thermal offset was positively correlated with the magnitude of thawing degree days at the ground surface:

(5.1) $\Delta T=\left(\frac{\lambda_{t}}{\lambda_{f}}-1\right) \frac{T D D}{365} \quad$ (Romanovsky and Osterkamp, 1995, eq. 12)

The thermal offset varied seasonally as the thermal properties of the active layer changed from the frozen to thawed state. During the freezing season, temperatures were warmer at the top of permafrost than at the ground surface and the thermal offset was positive (Table 5.6). During the thawing season, surface temperatures were warmer than the top of permafrost and the magnitude of the thermal offset was larger than the freezing season (Table 5.6), as the thermal conductivity of the active-layer was lower in a thawed state. Thawing-season thermal offset was largest at $\mathrm{T} 4\left(-7.8^{\circ} \mathrm{C}\right)$ where the active layer was deep and soil conditions were drier than at the other sites. The shallow active layer and low number of TDD at T6 yielded the lowest thermal offset during the thaw season. 


\subsection{The climate - permafrost relation}

The surface and thermal offsets have been discussed in this thesis as a means to separate the relation between climate and permafrost to explain the transfer of heat between the atmosphere and the ground surface, via the fluxes within the surface energy balance, and between the surface and the top of permafrost, primarily via conduction. Ultimately, the purpose of this separation is to determine the relative influence of surface and subsurface conditions on the climate-permafrost relation along the transect.

The total offset is the sum of the annual surface and thermal offsets. In this study, the annual surface offset was positive, as the surface was warmer than the air, and the thermal offset was negative, as the surface was warmer than the top of permafrost during the study period. Therefore, the magnitude of the total offset increases where the surface offset is large and the thermal offset approaches zero (Table 5.7). The total offset was predominately controlled by surface conditions as the magnitude of the surface offset was larger than that of the thermal offset, and the surface offset accounted for $86 \%$ (T1) to 93\% (T6) of the total offset at the study sites along the transect (Table 5.7).

Annually, temperatures at the top of permafrost were warmer than air temperatures at all sites (Table 5.7). The largest total offset was recorded at T2, where the deep snow cover resulted in a large surface offset, and the magnitude of the thermal offset was small due to a thin organic-layer and dry active-layer conditions. The total offset was smallest at $\mathrm{T} 5$ and $\mathrm{T} 6$, on the low shrub tundra, where the surface offset and the number of TDD was small. While the total offset is predominately controlled by surface conditions, subsurface conditions have a significant effect on the total offset between sites where surface conditions are similar. For example, snow conditions were 
Table 5.7 Annual, freezing and thawing-season total offsets at T1 to T6, September 1, 2004 to September 1, 2005.

\begin{tabular}{lcccccc}
\hline & T1 & T2 & T3 & T4 & T5 & T6 \\
\hline $\begin{array}{l}\text { Annual } \\
\text { Surface offset }\end{array}$ & & & & & & \\
Thermal offset & 5.1 & 5.8 & 5.6 & 5.2 & 4.4 & 4.3 \\
Total offset & -0.8 & -0.4 & -0.5 & -0.6 & -0.5 & -0.3 \\
& 4.3 & 5.4 & 5.0 & 4.6 & 3.9 & 4.0 \\
Freezing season & & & & & & \\
Surface offset & & & & & & \\
Thermal offset & 9.2 & 9.4 & 9.0 & 8.4 & 7.3 & 7.1 \\
Total offset & 2.2 & 3.0 & 2.4 & 3.0 & 2.9 & 2.2 \\
& 11.4 & 12.4 & 11.4 & 11.4 & 10.2 & 9.3 \\
$\begin{array}{l}\text { Thawing season } \\
\text { Surface offset }\end{array}$ & & & & & & \\
Thermal offset & & & & & & \\
Total offset & -3.3 & -1.7 & -2.4 & -1.5 & -1.9 & -2.2 \\
\hline Note: Accuracy & -7.2 & -7.0 & -6.8 & -7.8 & -7.4 & -5.4 \\
\hline
\end{tabular}

Note: Accuracy of the thermistors is $+/-0.5^{\circ} \mathrm{C}$, therefore accuracy of the total offset is $+/-1.0^{\circ} \mathrm{C}$ (see section 3.4.2). 
similar between T1, T2 and T3, however, the total offset was smaller at T1 due to the large thermal offset at the site (Table 5.7).

The relative influence of surface and subsurface conditions on the climatepermafrost relation varies seasonally (Table 5.7). During the freezing season, the difference between air and permafrost temperatures is primarily controlled by the insulating effect of the snow cover, and the surface offset is approximately 2 to 4 times larger than the thermal offset (Table 5.7). During the thaw season, the difference between air and permafrost temperatures is predominately controlled by subsurface conditions, as the thermal conductivity of the active-layer is less, and the thermal offset is approximately 2 to 5 times larger than the surface offset.

The magnitude of the total offset during the freezing season was only slightly larger than during the thawing season at most sites (Table 5.7), but the length of the freezing season ( $\sim 247$ days $)$ is approximately twice as long as the thaw season $(\sim 125$ days). Therefore, annually, surface conditions have a greater influence on the climatepermafrost relation than subsurface conditions at these sites. 


\section{Chapter 6}

\section{Summary and Conclusions}

\subsection{Summary of results}

This thesis has examined the physical relations that control differences in air and near-surface temperatures along a $90-\mathrm{km}$ transect across treeline in the uplands east of the Mackenzie Delta, NWT. During the one-year period of observation (2004-2005), the variability in air and near-surface temperatures was primarily controlled by changes in vegetation and snow cover. Differences in subsurface conditions across the transition had a significant effect on thawing-season surface temperatures, but during the freezing season any differences in subsurface conditions between sites were overridden by the influence of the snow cover.

\subsubsection{Variation in snow and vegetation across treeline}

Snow depth and vegetation height were positively correlated along the treeline transect. Mean end of winter snow depth decreased across treeline, from $78 \mathrm{~cm}$ in the open boreal woodland at $\mathrm{T} 1$, to $32 \mathrm{~cm}$ at the low shrub tundra at $\mathrm{T} 6$, in association with a decrease in vegetation height along the transect. The largest difference in mean snow depth $(15 \mathrm{~cm})$ occurred between the shrubby tussock tundra (T3) and the shrub tundra (T4) in association with a $32-\mathrm{cm}$ decrease in mean vegetation height between the sites. There was no statistically significant difference in mean snow depth between $\mathrm{T} 1$ and $\mathrm{T} 3$, even though the decrease in mean vegetation height between sites was statistically 
different. Mean end of winter snow depths were also similar between T4 and T6, as vegetation height changed very little north of T4.

The distribution of snow cover across treeline was controlled by the distribution of vegetation along the gradient and reflects two potential supplies of snow: 1) the atmospheric supply of snow; and 2) the redistribution of snow by wind from local and regional sources. Within the open boreal woodland (T1) and the tall shrub site (T2), redistribution of the snow cover was limited as strong winds were inhibited at the sites due to the tall vegetation. Therefore, snow depths at $\mathrm{T} 1$ and $\mathrm{T} 2$ primarily reflected the atmospheric supply of snow to the area and were similar at these sites.

Wind redistribution of the snow cover was common at the shrubby tussock tundra site (T3) due to the wide spacing of the large, structurally complex alders, but the net loss of snow from the site was small, as deep snow drifts formed in and around large alders at the site and retained much of the redistributed snow. The result was a highly variable snow cover at $\mathrm{T} 3$, and a mean snow depth not statistically different from $\mathrm{T} 1$ and $\mathrm{T} 2$. Wind redistribution of the snow cover was also common at the shrub tundra and low shrub tundra sites (T4 to T6), but the height of the vegetation at these sites was low, therefore snow quickly exceeded the retention threshold of the vegetation and was transported away from the site. Consequently, snow depths were thin and similar at sites $\mathrm{T} 4, \mathrm{~T} 5$, and $\mathrm{T} 6$.

\subsubsection{Variation in air and near-surface ground temperatures across treeline}

A gradient in near-surface ground temperatures existed across treeline, as annual mean near-surface ground temperatures decreased along the transect at all measured 
depths $(5,50$ and $100 \mathrm{~cm})$. While the ecological transition from forest to tundra was not a sharp boundary, neither was the change in near-surface ground temperatures. Annually, temperatures at the top of permafrost decreased from $-4.0^{\circ} \mathrm{C}$ at the boreal site (T1) to $-6.7^{\circ} \mathrm{C}$ at the low shrub site (T6), but the greatest difference in top of permafrost temperatures $\left(1.1^{\circ} \mathrm{C}\right)$ occurred between two tundra sites, the shrubby tussock tundra site (T3) and the shrub tundra site (T4), in association with a steep decrease in vegetation height and snow depth. This large change in near-surface ground temperature between two tundra sites, $7 \mathrm{~km}$ apart, highlights the importance of shrub density in determining the snow retention capacity of an area and ultimately the ground thermal regime.

Differences in winter conditions are primarily responsible for the gradient in annual mean near-surface ground temperatures across the treeline transition. During the freezing-season, air temperatures were variable along the transect, due to spring differences in net radiation between the sites. Near-surface ground temperatures, however, were controlled by snow conditions across the transition as near-surface ground temperatures were perfectly correlated with mean end-of-winter snow thickness. Nearsurface ground temperatures were highest in the open boreal woodland (T1), as deep snow retarded heat loss from the ground. Near-surface ground temperatures were lowest and followed changes in air temperature more closely at the low shrub tundra sites (T5 and T6), where snow depths were thin.

During the thawing season, a steep air temperature gradient existed across treeline due to differences in net radiation between the open boreal woodland and the tundra sites, and a coastal effect at the northern end of the transect. The steep air temperature gradient was not registered at the ground surface, as differences in near-surface thermal diffusivity 
and canopy cover attenuated the differences in air temperature and temperatures at the top of permafrost were constrained by latent heat effects.

An investigation of the climate-permafrost relation through the surface and thermal offset revealed the relative importance of surface and subsurface conditions on the ground thermal regime. Once the ground was uniformly frozen, surface conditions had a greater effect on the ground thermal regime, as the presence of the snow cover interposed a buffer layer between the atmosphere and the ground surface. During the thawing season, the snow cover disappeared and the ground thermal regime was controlled by subsurface conditions, including the thickness of the organic layer, the surface moisture content and the ice content of the active layer. Because the freezing season was approximately twice as long as the thawing season, the influence of the freezing season is significantly greater and annual mean near-surface ground temperatures were dominated by differences in winter surface conditions.

\subsection{Conclusions}

The following three conclusions can be drawn from the examination of the relations between vegetation, snow cover, and air and near-surface ground temperatures at the study sites across treeline presented in this thesis:

(1) The characteristics of the vegetation cover controlled the distribution of snow across the treeline transition, and ultimately the ground thermal regime. 
(2) Snow depths in the open boreal woodland and the tall shrub zone represented the atmospheric supply of snow to the area. Tundra snow depths were controlled by wind redistribution and the snow retention capacity of the vegetation at the site.

(3) Near-surface ground temperatures were primarily controlled by surface conditions when the ground was uniformly frozen, and by subsurface conditions during the thawing season. On an annual scale, surface conditions had a greater effect on the gradient in near-surface ground temperatures across treeline, due to the length of the freezing season.

\subsection{Broader implications and directions for future research}

The conclusions of this research have broad implications in the context of resource management issues and climate change. Resource managers, regulators, and industry involved in oil and gas development in the Mackenzie Delta region should be aware of the importance of winter conditions on the ground thermal regime. The modification of winter conditions through human manipulation of the vegetation cover or climatic change will have significant effects on the ground thermal regime.

Increased shrubiness of the arctic tundra associated with climate change predictions will influence the distribution of tundra snow cover and ultimately the ground thermal regime. This research highlighted the steep change in near-surface ground temperature between two tundra sites, the shrubby tussock tundra and the shrub tundra, due to a difference in the density of large alder shrubs. Future research should be 
directed to the investigation of shrub density on the distribution of snow cover and the ground thermal regime, as perhaps a threshold density of shrubs exists in controlling snow depth in an area.

The results of this research explain the physical relations which control nearsurface ground temperatures across treeline in the Western Canadian Arctic through one year. Worthwhile future research would include investigating the interannual variation in snow conditions and near-surface ground temperatures across treeline in the study area, as snow conditions are highly variable year to year, and this will consequently have an effect on near-surface ground temperatures. 


\section{References}

ACGR. 1988. Glossary of permafrost and related ground-ice terms. Permafrost Subcommittee, Associate Committee on Geotechnical Research. National Research Council of Canada, Ottawa. $156 \mathrm{pp}$.

Barry, R.G. 1967. Seasonal location of the arctic front over North America. Geographical Bulletin, 9: 79-95.

Beringer, J., Chapin III, F.S., Thompson, C.C., and McGuire, A.D. 2005. Surface energy exchanges along a tundra-forest transition and feedbacks to climate. Agricultural and Forest Meteorology, 131: 143-161.

Brady, N. and Weil, R. 2002. The Nature and Properties of Soils. Prentice-Hall, New Jersey. $960 \mathrm{pp}$.

Bryson, R.A. 1966. Streamlines, air masses, and the boreal forest. Geographical Bulletin, 8: 228-269.

Burgess, M.M. and Smith, S.L. 2000. Shallow ground temperatures. In The Physical Environment of the Mackenzie Valley, Northwest Territories: a Base Line for the Assessment of Environmental Change, edited by L.D. Dyke and G.R. Brooks. Geological Survey of Canada, Bulletin 547, p. 89-103.

Burn, C.R. 1997. Cryostratigraphy, paleogeography, and climate change during the early Holocene warm interval, western Arctic coast, Canada. Canadian Journal of Earth Sciences, 34: 912-925.

Burn, C.R. 1998. The response (1958-1997) of permafrost and near-surface ground temperatures to forest fire, Takhini River valley, southern Yukon Territory. Canadian Journal of Earth Sciences, 35: 184-199.

Burn, C.R. 2004. The thermal regime of cryosols. In Cryosols: Permafrost Affected Soils, edited by J.M. Kimble. Springer. Berlin. 726 pp.

Burn, C.R., and Smith, C.A.S. 1988. Observations of the "Thermal Offset" in nearsurface mean annual ground temperatures at several sites near Mayo, Yukon Territory, Canada. Arctic, 41: 99-104.

Dyke, L.D. 2000. Climate of the Mackenzie River Valley. In The Physical Environment of the Mackenzie Valley, Northwest Territories: a Base Line for the Assessment of Environmental Change, edited by L.D. Dyke and G.R. Brooks. Geological Survey of Canada, Bulletin 547, p. 143-151. 
Eaton, A.K., and Rouse, W.R. 2001. Surface energy balance of the western and central canadian subarctic: variations in the energy balance among five major terrain types. Journal of Climate, 14: 3692-3703.

Ecoregions Working Group. 1989. Ecoclimatic Regions of Canada; Canada Committee on Ecological Land Classification, Environment Canada. Ecological Land Classification series, no.23, $118 \mathrm{pp}$.

Essery, R., Li, L., and Pomeroy, J. 1999. A distributed model of blowing snow over complex terrain. Hydrological Processes, 13: 2423-2438.

Essery, R., and Pomeroy, J. 2004. Vegetation and topographic control of wind-blown snow distributions in distributed and aggregated simulations for an arctic tundra basin. Journal of Hydrometeorology - Special section, 5: 735-744.

Eugster, W., Rouse, W., Pielke Sr, R., McFadden, J., Baldocchi, D., Kittel, T., Chapin III, F.S., Liston, G., Vidale, P., Vaganov, E., and Chambers, S. 2000. Landatmosphere energy exchange in Arctic tundra and boreal forest: available data and feedbacks to climate. Global Change Biology, 6: 84-115.

Evans, B., Walker, D., Benson, C., Nordstrand, E., and Peterson, G. 1989. Spatial interrelationships between terrain, snow distribution and vegetation patterns at an arctic foothills site in Alaska. Holarctic Ecology, 12: 270-278.

Flannigan, M.D., Stocks, B.J., Wotton, B.M. 2000. Climate change and forest fires. Science of the Total Environment, 262: 221-229.

Gold, L.W., and Lachenbruch, A.H. 1973. Thermal conditions in permafrost: a review. In Proceedings of the Second International Conference on Permafrost, Yakutsk, USSR, North American Contribution, Washington, D.C.: National Academy of Science: $3-25$.

Goodrich, L.E. 1982. The influence of snow cover on the ground thermal regime. Canadian Geotechnical Journal, 19: 421-432.

Grace, J. 1989. Tree lines. Philosophical Transactions - Royal Society of London, 324: 233-245.

Grace, J., Berninger, F., and Nagy, L. 2002. Impacts of climate change on the treeline. Annnals of Botany, 90: 537-544.

Hare, F.K. 1968. The Arctic. Quarterly Journal of the Royal Meteorological Society, 94: 439-459.

Hare, F.K., 1997. Canada's climate: An overall perspective. In The Surface Climates of Canada, edited by Bailey, W.G., Oke, T.R., Rouse, W.R. McGill-Queens Press. $484 \mathrm{pp}$. 
Hare, F.K., and Ritchie, J.C. 1972. The boreal bioclimates. Geographical Review, 62: 333-365.

Heginbottom, J.A., Dubreuil, M.A., and Harker, P.A. 1995. Canada - Permafrost. In National Atlas of Canada, $5^{\text {th }}$ edition. Natural Resources Canada, Ottawa. Plate 2.1, MCR 4177. http://atlas.nrcan.gc.ca/site/english/maps/environment/land/permafrost

Heikkinen, O., Tuovinen, M., and Autio, J. 2002. What determines the timberline? Fennia, 180: 67-74.

Henry, J.D. 2002. Canada's Boreal Forest. Smithsonian Institution Press, Washington. $176 \mathrm{pp}$.

Henry, K., and Smith, M.W. 2001. A model-based map of ground temperatures for the permafrost regions of Canada. Permafrost and Periglacial Processes, 12: 389-398.

Hinkel, K.M., and Outcalt, S.I. 1994. Identification of heat-transfer processes during soil cooling, freezing, and thaw in central Alaska. Permafrost and Periglacial Processes, 5: 217-235.

Jorgenson, M.T., and Kreig, R.A. 1988. A model for mapping permafrost distribution based on landscape component maps and climatic variables. In Proceedings, $5^{\text {th }}$ International Conference on Permafrost. August 2-5, 1988. Trondheim, Norway. pp. 176-182.

Karunaratne, K.C. 2002. N-factors and the relations between air and surface temperature in discontinuous permafrost near Mayo, Yukon Territory. MSc. thesis. Carleton University, Ottawa, Ontario.

Karunaratne, K.C., and Burn, C.R. 2004. Relations between air and surface temperature in discontinuous permafrost terrain near Mayo, Yukon Territory, Canadian Journal of Earth Sciences, 41: 1437-1451.

Klene, A.E., Nelson, F.E., and Shiklomanov, N.I. 2001. The n-factor in natural landscapes: variability of air and soil-surface temperatures, Kuparuk River basin, Alaska, USA. Arctic, Antarctic and Alpine Research, 33: 140-148.

Kokelj, S.V., and Burn, C.R. 2003. Ground ice and soluble cations in near-surface permafrost, Inuvik, Northwest Territories. Permafrost and Periglacial Processes, 14: $275-289$.

Kokelj, S.V., and Burn, C.R. 2005. Near-surface ground ice in sediments of the Mackenzie Delta, Northwest Territories, Canada. Permafrost and Periglacial Processes, 16: 291-303. 
Kokelj, S.V., Jenkins, R.E., Milburn, D., Burn, C.R., and Snow, N. 2005. The influence of thermokarst disturbance on the water quality of small upland lakes, Mackenzie Delta region, Northwest Territories, Canada. Permafrost and Periglacial Processes, 16: 343-353.

Kokelj, S.V., Smith, C.A.S., and Burn, C.R. 2002. Physical and chemical characteristics of the active layer and permafrost, Herschel Island, Western Arctic Coast, Canada. Permafrost and Periglacial Processes, 13: 171-185.

Lafleur, P.M., Renzetti, A.V., and Bello, R. 1993. Seasonal changes in the radiation balance of subarctic forest and tundra. Arctic and Alpine Research, 25: 32-36.

Lachenbruch, A.H., Cladouhos, T.T., and Saltus, R.W. 1988. Permafrost temperature and the changing climate. In Proceedings of the $5^{\text {th }}$ International Conference on Permafrost, 2-5 August 1988, Trondheim, Norway, edited by K. Senneset. Tapir publishers, Trondheim, Norway, Vol. 3: 9-17.

Landhausser, S.M., and Wein, R.W. 1993. Postfire vegetation recovery and tree establishment at the Arctic treeline: climate-change-vegetation-reponse hypothesis. Journal of Ecology, 81: 665-672.

Larsen, J. 1980. The Boreal Ecosystem. Academic Press, New York. 500 pp.

Larsen, J. 1989. The Northern Forest Border in Canada and Alaska: Biotic communities and ecological relationships. Ecological Studies 70. Springer-Verlag, Rhinelander. $255 \mathrm{pp}$.

LICOR, 1992. LAI-2000 Plant Canopy Analyzer Operating Manual. LICOR Inc. Lincoln, Nebraska. $179 \mathrm{pp}$.

Ling, F. and Zhang, T. 2003. The impact of the timing and duration of seasonal snowcover on the active layer and permafrost in the Alaskan Arctic. Permafrost and Periglacial Processes, 14: 141-150.

Lunardini, V.J. 1978. Theory of n-factors and correlation of data. In Proceedings, $3^{\text {rd }}$ International Conference on Permafrost. Edmonton, Alberta. July 10-13, 1978. National Research Council of Canada. Ottawa: 40-46.

Lunardini, V.J. 1981. Heat Transfer in Cold Climates. New York: Van Nostrand Reinhold. $731 \mathrm{pp}$.

MacDonald, G.M. 2000. Postglacial vegetation and climate; In The Physical Environment of the Mackenzie Valley, Northwest Territories: a Base Line for the Assessment of Environmental Change, edited by Dyke, L.D. and G.R. Brooks. Geological Survey of Canada, Bulletin 547: 57-63. 
Mackay, J.R. 1963. The Mackenzie Delta area, NWT Geographical Branch, Department of Mines and Technical Surveys, Ottawa, Memoir 8.

Mackay, J.R. 1995. Active layer changes (1968-1993) following the forest-tundra fire near Inuvik, NWT, Canada. Arctic and Alpine Research, 27: 323-336.

Mackay, J.R., and MacKay, D.K. 1974. Snow cover and ground temperatures, Garry Island, N.W.T. Arctic, 27. pp 287-296.

Mackay, J.R., and Burn, C.R. 2002. The first 20 years (1978-1979 to 1998-1999) of active layer development, Illisarvik experimental drained lake site, western Arctic coast, Canada. Canadian Journal of Earth Sciences, 39: 1657-1674.

McCoy, V.M., and Burn, C.R. 2005. Potential alteration by climate change of the forestfire regime in the boreal forest of central Yukon Territory. Arctic, 58: 276-285.

Morrison, J., Aagard, K., and Steele, M. 2000. Recent environmental changes in the Arctic: a review. Arctic, 53: 359-371.

Mueller-Dombois, D., and Ellenberg, H. 2003. Aims and methods of vegetation ecology. $5^{\text {th }}$ edition. The Blackburn Press, New Jersey. $547 \mathrm{pp}$.

Myneni, R., Keeling, C., Tucker, C., Asrar, G., and Nemani, R. 1997. Increased plant growth in the northern high latitudes from 1981 to 1991. Nature, 386: 698-702.

Nicholson, F.M., and Granberg, H.B. 1973. Permafrost and snowcover relationships near Schefferville. Second International Conference on Permafrost. Yakutsk, USSR. North American Volume: 151-158.

Nixon, F.M. 2000. Thaw-depth monitoring. In The Physical Environment of the Mackenzie Valley, Northwest Territories: a Base Line for the Assessment of Environmental Change, edited by L.D. Dyke and G.R. Brooks. Geological Survey of Canada, Bulletin 547: 119-126.

Oke, T.R. 1987. Boundary Layer Climates. $2^{\text {nd }}$ edition. Routledge, London. $435 \mathrm{pp}$.

Oke, T.R. 1997. Surface climate processes. In The Surface Climates of Canada, edited by Bailey, W.G., Oke, T.R., Rouse, W.R. McGill-Queens Press. 484 pp.

Payette, S., Filion, L., Delwaide, A., and Begin, C. 1989. Reconstruction of treeline vegetation response to long-term climate change. Nature, 341: 429-432.

Payette, S., Fortin, M-J., and Gamache, I. 2001. The subarctic forest-tundra: the structure of a biome in a changing climate. Bioscience, 51: 709-718. 
Pomeroy, J.W. and Gray, D.M. 1995. Snow Accumulation, Relocation and Management. National Hydrology Research Institute Science Report No. 7. Environment Canada: Saskatoon. 144 pp.

Rampton, V.N. 1988. Quaternary geology of the Tuktoyaktuk Coastlands, Northwest Territories. Geological Survey of Canada, Memoir 423.

Riseborough, D.W., and Smith, M.W. 1998. Exploring the limits of permafrost. In Proceedings Permafrost: $7^{\text {th }}$ International Conference. Yellowknife, Canada. Edited by Lewkowicz, A.G., and Allard, M. Nordicana, Quebec: 935-942.

Ritchie, J.C. 1984. Past and present vegetation of the far northwest of Canada. University of Toronto Press, Toronto. pp 48-65.

Romanovsky, V.E., and Osterkamp, T.E. 1995. Interannual variations of the thermal regime and near-surface permafrost in northern Alaska. Permafrost and Periglacial Processes, 6: 313-335.

Rouse, W. 1984a. Microclimate of Arctic treeline: Radiation balance of tundra and forest. Water Resources Research, 20: 57-66.

Rouse, W. 1984b. Microclimate of Arctic treeline: Soil microclimate of tundra and forest. Water Resources Research, 20: 67-73.

Seppala, M., 1994. Snow depth controls palsa growth. Permafrost and Periglacial Processes, 5. 283-288.

Serreze, M.C., Walsh, J.E., Chapin, F.S., Osterkamp, T., Dyurgerov, M., Romanovsky, V., Oechel, W.C., Morrison, J., Zhang, T., and Barry R.G. 2000. Observational evidence of recent change in the northern high-latitude environment. Climate Change, 46: 159-207.

Smith, C.A.S., Burn, C.R., Tarnocai, C., and Sproule, B. 1998. Air and soil temperature relations along an ecological transect through the permafrost zones of northwestern Canada. Proceedings, $7^{\text {th }}$ International Conference on Permafrost, Yellowknife, N.W.T: 1009-1015.

Smith, M.W. 1975. Microclimatic influences on ground temperatures and permafrost distribution, Mackenzie Delta, Northwest Territories. Canadian Journal of Earth Sciences, 12: 1421-1438.

Smith, S.L., and Burgess, M.M. 1998. Mapping the response of permafrost in Canada to climate warming. In Current Research, Part E; Geological Survey of Canada: 163-171. 
Smith, M.W., and Riseborough, D.W. 2002. Climate and the limits of permafrost: A zonal analysis. Permafrost and Periglacial Processes, 13: 1-15.

Sokal, R.R., and F.J. Rohlf, 1995. Biometry. 3rd edition. W.H. Freeman and Co., New York. $887 \mathrm{pp}$.

Sturm, M., and Benson, C.S., 1997. Vapor transport, grain growth and depth-hoar development in the subarctic snow. Journal of Glaciology, 43: 26-41.

Sturm, M., Holmgren, J., Konig, M., and Morris, K. 1997. The thermal conductivity of seasonal snow. Journal of Glaciology, 43: 42-59.

Sturm, M., McFadden, J., Liston, G., Chapin III, F.S., and Holmgren, J. 2001b. Snowshrub interactions in Arctic tundra: A hypothesis with climatic implications. Journal of Climate, 14: 336-344.

Sturm, M., Racine, C., and Tape, K. 2001a. Increasing shrub abundance in the Arctic. Nature, 411: 546-547.

Sturm, M., Schimel, J., Michaelson, G., Welker, J.M., Oberbauer, S.F., Liston, G.E., Fahnestock, J., and Romanovsky, V.E. 2005. Winter biological processes could help convert arctic tundra to shrubland. Bioscience, 55: 17-26.

Tarnocai, C. 2004a. Classification of cryosols in Canada. In Cryosols: Permafrost Affected Soils, edited by J.M. Kimble. Springer. Berlin. 726 pp.

Tarnocai, C. 2004b. Cryosols of Arctic Canada. In Cryosols: Permafrost Affected Soils, edited by J.M. Kimble. Springer. Berlin. $726 \mathrm{pp}$.

Taylor, A.E. 1995. Field measurements of n-factors for natural forest areas, Mackenzie Valley, Northwest Territories. Geological Survey of Canada. Current Research 1995-B: 89-98.

Taylor, A.E. 2000. Relationship of ground temperatures to air temperatures in forests. In The Physical Environment of the Mackenzie Valley, Northwest Territories: a Base Line for the Assessment of Environmental Change, edited by Dyke, L.D. and G.L. Brooks. Geological Survey of Canada, Bulletin 547: 111-117.

Thompson, C., Beringer, J., Chapin III, F.S., and McGuire, A.D. 2004. Structural complexity and land-surface energy exchange along a gradient from arctic tundra to boreal forest. Journal of Vegetation Science, 15: 397-406.

Timoney, K.P., G.H.L. Roi, S.C. Zoltai, and A.L. Robinson. 1992. The high subarctic forest-tundra of northwestern Canada: position, width, and vegetation gradients in relation to climate. Arctic, 45: 1-19. 
Timoney, K.P., G.H.L. Roi, and M.R.T. Dale. 1993. Subarctic forest-tundra vegetation gradients: the sigmoid wave hypothesis. Journal of Vegetation Science, 4: 387394.

Williams, P.J. and Smith, M.W. 1989. The Frozen Earth: Fundamentals of Geocryology. Cambridge University Press, Cambridge. 306 pp.

Woo, M. 1997. A guide for ground based measurement of the Arctic snow cover. Climate Research Branch, Atmospheric Environment Service, Environment Canada. 30 pp.

Zhang, T., Osterkamp, T.E., and Stamnes, K. 1996. Influence of the depth hoar layer of the seasonal snow cover on the ground thermal regime. Water Resources Research, 32: 2075-2086.

Zhang, T. and Stamnes, K. 1998. Impact of climatic factors on the active layer and permafrost at Barrow, Alaska. Permafrost and Periglacial Processes, 9: 229-246.

Zhang, T., Barry, R.G., Knowles, K., Heginbottom, J.A., Brown, J. 1999. Statistics and characteristics of permafrost and ground ice distribution in the Northern Hemisphere. Polar Geography, 23: 132-154.

\section{Internet sources}

Environment Canada. 1995. Terrestrial ecozones of Canada. http://www.ec.gc.ca/soerree/English/Framework/Nardesc/TOC.cfm (Last accessed June 14, 2006)

Environment Canada. 2004. Canadian climate normals 1971-2000.

http://www.climate.weatheroffice.ec.gc.ca/climate_normals (Last accessed April $1,2007)$

Environment Canada. 2005. Daily climate data for Inuvik and Tuktoyaktuk, March 2005. http://climate.weatheroffice.ec.gc.ca/climateData/dailydata_e.html (Last accessed April 1, 2007) 